ALEXANDRE MiURA IURA

\title{
ORALIDADE E ESCRITA NO PROCESSO CIVIL
}

\author{
DisSERTAÇÃO DE MESTRADO
}

ORIENTADOR: PROFESSOR TITULAR JOSÉ ROGÉRIO CRUZ E TUCCI

FACUlDADE DE DiReITO DA UNIVERSIDADE DE SÃo PAULO SÃO PAULO

2012 
ALEXANDRE MiURA IURA

\section{ORALIDADE E ESCRITA NO PROCESSO CIVIL}

Dissertação apresentada como requisito parcial para a obtenção do título de Mestre, junto ao Departamento de Direito Processual da Faculdade de Direito da Universidade de São Paulo.

ORIENTADOR: PROFESSOR TITULAR JOSÉ ROGÉRIO CRUZ E TUCCI

FACULDADE DE DiREITO DA UNIVERSIDADE DE SÃo PAULO SÃO PAULO 


\section{ORALIDADE E ESCRITA NO PROCESSO CIVIL}

Dissertação apresentada como requisito parcial para a obtenção do título de Mestre, junto ao Departamento de Direito Processual da Faculdade de Direito da Universidade de São Paulo.

Orientador: Professor Titular José Rogério Cruz e Tucci

Aprovado em:

BANCA EXAMINADORA

Prof.

Instituição:

Julgamento: Assinatura:

Prof.

Instituição:

Julgamento: Assinatura:

Prof.

Instituição:

Julgamento: Assinatura: 
À memória de Luiz Carlos de Azevedo (1932-2011), um gentleman na acepção mais estrita do termo. 


\section{AGRADECIMENTOS}

Agradeço ao professor e amigo José Rogério Cruz e Tucci, pela minha iniciação no estudo do Direito Processual, desde os bancos da graduação no Largo de São Francisco, e pela confiança depositada ao longo destes anos.

Agradeço aos professores José Luiz Gavião de Almeida e José Carlos Baptista Puoli pelas preciosas observações prestadas na banca de qualificação.

Por fim, agradeço ao amigo José Rubens de Moraes, pelo paciente auxílio no levantamento bibliográfico. 


\section{RESUMO}

O objetivo principal desta dissertação é apresentar a Oralidade e a Escrita no Processo Civil sob a ótica do Gerenciamento de Processos. Deste modo, é negada que a oralidade constitua um princípio formador do Direito Processual Civil, destacando-se que se trata de uma escolha técnica dada ao órgão jurisdicional visando maior eficiência. É questionada a funcionalidade das audiências e da prova oral. É enfatizado que o papel da conciliação é promover o acesso à justiça, e não reduzir gastos públicos. De outro lado, é sustentado que a garantia de um processo justo é compatível com um procedimento escrito. À guisa de conclusão, é afirmado que a oralidade não pode ser tratada exclusivamente no plano dos princípios. Com o consenso das partes, pode o juiz customizar as audiências e a colheita das provas visando dar maior eficiência ao processo.

Palavras-chave: Direito Processual Civil - Oralidade e Escrita - Procedimento em Primeiro Grau - Audiências - Prova Testemunhal - Gerenciamento de Processos 


\begin{abstract}
This essay overriding objective is to present Orality and Writing in Civil Procedure in a Case Management view. By doing so, it is denied that orality constitutes a formative principle of Civil Procedure, rather than a technical choice given to the court in order to bring more efficiency to the procedure. The oral hearing and proof gathering functionality is also questioned. It is emphasized that the role of conciliation is to improve access to justice and it is not its aim to reduce public expenses. In another hand, it's sustained that the guarantee of a fair public hearing is compatible with a writing procedure. As a conclusion, it is said that orality and writing cannot be treated exclusively as a matter of principle. With the consent of the parties, the judge can customize the hearings and proof taking, giving more efficiency to the civil procedure.
\end{abstract}

Keywords: Civil Procedure - Orality and Writing - First Instance Procedure - Hearings - Testimonial Proof - Case Management 


\section{SUMÁRIO}

1 INTRODUÇÃO....................................................................................... 10

2 PARTE HISTÓRICA................................................................................. 11

2.1 Significado da oralidade no processo civil romano de época arcaica............ 12

2.2 A oralidade desvinculada da prova no período das ações da lei: o processo civil como disputa retórica e a inexistência de uma teoria da prova.............. 15

2.3 Concentração procedimental e variações interpretativas da regra solis accasus suprema tempestas esto............................................................. 17

2.4 A natureza pública do processo como pressuposto do sistema da oralidade.... 20

2.5 Prova legal no Baixo Império..................................................................... 24

$2.6 \quad$ Irrecorribilidade das interlocutiones.............................................................. 25

2.7 Provimentos fundados em prova semiplena no período da extraordinaria cognitio: sumarização da cognição.............................................................. 28

2.8 Sumarização da forma, Clementina Saepe e os plenários rápidos................ 29

2.9 Oralidade no direito romano vulgar e nos direitos germânicos na Península Ibérica.

2.10 Oralidade e escritura no processo do período da consolidação da monarquia portuguesa........................................................................................... 35

2.11 Oralidade e escritura no processo civil das Ordenações do Reino................. 36

2.11.1 Tentativa de conciliação e comparecimento pessoal das partes......... 36

2.11.2 Ausência de cooperação do juiz com as partes................................. 39

2.11.3 Do julgamento pela verdade sabida sem embargo do erro do processo...

2.11.4 Introdução da demanda de forma oral.

2.11.5 Mediação na colheita da prova testemunhal e oitiva das partes sem a presença do julgador.

2.11.6 Reinquirição de testemunhas no tribunal.

2.12 A disposição provisória de 1832 e a oralidade na visão de Moacyr Lobo da Costa.

2.13 Código do Processo do Estado da Bahia de 1915 e a influência da ZPO austríaca de 1895 sobre o pensamento de Eduardo Espínola

2.14 Código de processo civil de 1939: o descompasso entre a exposição de motivos e o código.

2.15 Conclusão parcial.

3 CONSTRUÇÕES DOGMÁTICAS DA ORALIDADE....................................... 54

3.1 Negação do valor apriorístico da oralidade (Adolf Wach).............................. 54

3.2 Oralidade e os poderes do juiz no pensamento de Franz Klein....................... 55 
3.3 Oralidade no pensamento de Giuseppe Chiovenda

3.3.1 A influência da concepção chiovendiana de oralidade na doutrina brasileira

3.3.2 Motivação política de Chiovenda em sustentar a prevalência da oralidade em sua concepção contemporânea no processo civil romano.

3.3.3 Argumentos utilizados por Chiovenda para sustentar a prevalência da oralidade em sua acepção moderna no processo civil romano...... 58

3.3.4 A motivação política no pensamento de Chiovenda.......................... 60

3.4 Significados da oralidade para Mauro Cappelletti......................................... 63

4 ORALIDADE COMO REGRA TÉCNICA E NÃO COMO PRINCÍPIO PROCESSUAL

5 ORALIDADE E DEVIDO PROCESSO LEGAL NUMA PERSPECTIVA COMPARATIVA.

6 ORALIDADE E COOPERAÇÃO NO PROCESSO.

7 ORALIDADE NA FASE PRELIMINAR

7.1 Oralidade na fase postulatória.

7.2 Introdução da demanda de forma oral ou por formulários como meio de permitir o acesso à justiça.

7.3 A designação da audiência preliminar como uma questão de conveniência: em defesa do regime facultativo da audiência preliminar.

7.4 As demandas de pequeno valor e a facultavidade da audiência.

8 ORALIDADE E A TENTATIVA DE CONCILIAÇÃO.

8.1 Mediação pré-processual obrigatória na Alemanha (§15 da EGZPO).......... 90

8.2 Mediação pré-processual obrigatória em Ontário

8.3 Conciliação obrigatória e flexibilidade do procedimento na alemanha: a Güteverhandlung e as reformas de 2001 da ZPO....

8.4 O mito da mentalidade japonesa de resolução de conflitos de forma não adjudicada.

8.5 Projeto de Lei que altera a redação do artigo 331 do CPC - PLC 94/2002 elaborado pelo IBDP

8.6 Análise do Projeto de Lei da Câmara 94/2002 no que se refere à nova redação do artigo 331 do CPC.

8.7 Audiência de conciliação no Projeto de Lei do Senado 166/2010 (Projeto do Novo CPC).

8.8 O conciliador e o mediador no Projeto de Lei do Senado 166/2010 (Projeto do Novo CPC).

8.9 A concentração procedimental na fase preliminar: uma questão de redução de custos. 
9 ORALIDADE NA AUDIÊNCIA DE INSTRUÇÃO.

9.1 Formas de produção da prova testemunhal: os depoimentos escritos, os depoimentos gravados e a videoconferência.

9.1.1 Admissão dos affidavits como prova

9.1.2 Inaplicabilidade do right to confrontation no âmbito do processo civil

9.2 As novas tecnologias da informação e as formas no processo civil. 116

9.3 A gravação das audiências, a videoconferência e a imediação

10 O MITO DO JUIZ POLÍGRAFO

11 O VERDADEIRO VALOR DA IMEDIAÇÃO E A FALSIDADE DO PARADOXO “ORALIDADE E DUPLO GRAU DE JURISDIÇÃO”.

12 ORALIDADE NAS DEMANDAS ENVOLVENDO DIREITO DE FAMÍLIA.

13 CONCLUSÃO

BIBLIOGRAFIA. 


\section{INTRODUÇÃO}

A oralidade é um tema sempre presente na pauta de discussão do processualista. Prova disso foi o recente colóquio Oral and Written Proceedings: Efficiency in Civil Procedure, realizado pela Associação Internacional de Direito Processual, em novembro de 2008, em Valência, na Espanha.

Deveras, a Academia Internacional de Direito Comparado já havia abordado o tema da oralidade no Congresso de Londres de 1950, e no de Pescara em 1970 (no qual MAURO CAPPELLETTI apresentou o célebre relatório geral Procédure Orale et Procédure Écrite ${ }^{1}$.

Todavia, a despeito da riqueza do tema, a doutrina processual brasileira limita-se a reproduzir a centenária construção de CHIOVENDA e, quando muito, faz referência ao Stuttgarter Model da década de 1970, já profundamente alterado após as recentes reformas da $Z P O$.

Neste cenário, entende-se propício revisitar o tema da oralidade, para questionar a atualidade de seus postulados, e atribuir novos significados ao conceito, ainda que para tanto seja necessário “destroçar sacrilegamente os ossos de Chiovenda”, tal como já alertava Victor Nunes Leal às vésperas da promulgação do Código de Processo Civil de $1939 .^{2}$

\footnotetext{
1 CAPPELLETTI, Mauro. Procédure Orale et Procédure Écrite - Oral and Written Procédure in Civil Litigation. Milano; New York: Giuffrè; Oceana, 1971.

2 Daqui a cincoenta anos nós é que seremos batidos como reacionários. Quando os modernos de 1990 exhumarem e destroçarem sacrilegamente os ossos de Chiovenda, nós também arrancaremos os cabelos brancos de desespero clamando: Esses moços de hoje estão doidos, Já não temos mais juristas... NUNES LEAL, Victor. Ignorância, rotina e chicana - os três maiores inimigos do Processo Oral. Revista Forense, maio 1938, p. 121.
} 


\section{PARTE HISTÓRICA}

Os direitos da Antiguidade devem ser estudados levando-se em conta sua autonomia em relação ao presente. Buscar imprimir ao passado uma lógica própria do direito contemporâneo implicaria obter conclusões distorcidas e inaceitáveis no âmbito de uma pesquisa científica.

Não se quer afirmar que o uso de conceitos modernos no estudo de direitos antigos seja por si só um erro metodológico. ${ }^{3}$ Por vezes este é o único mecanismo disponível para o estudioso explicar determinado instituto diante da incompletude das fontes. O que se quer dizer é que o uso de conceitos modernos para explicar fenômenos passados, atribuindo-se ao homem antigo consciência e estado de espírito tipicamente contemporâneos, acaba por distorcer o objeto analisado. ${ }^{4}$

Transportando a discussão para o tema deste trabalho, é possível afirmar genericamente que o processo civil romano era caracterizado pela oralidade, a despeito de este conceito ter sido formulado em termos científicos no plano da teoria da prova apenas no século XIX. Nestes termos, o princípio da oralidade é utilizado como instrumento numa análise meramente descritiva do processo, para afirmar que os elementos identificadores do processo oral estavam presentes no processo civil romano, com maior ou menor intensidade, dependendo do período em questão. ${ }^{5}$

3 Ideas attributed to antiquity are not wrong because they happen to be modern, and in any event anachronism is extremely useful in the study of procedure. METZGER, Ernest. Roman Judges, Case Law, and Principles of Procedure. Law and History Review, Illinois, University of Illinois, n. 22, summer, 2004. p. 247.

${ }_{4}$ If we set out to explain events by assigning modern motives or states of mind to the actors, then we have strayed into bad anachronism, because we are making spurious connections between human actions and the events being explained. METZGER, Ernest. Roman Judges, Case Law, and Principles of Procedure, p. 248.

5 KASER, possivelmente a voz mais autorizada em processo civil romano da segunda metade do século XX, discorre sobre oralidade e imediação no período clássico em termos descritivos, ressalvando que em grande parte estes princípios foram abandonados em época pós-clássica. KASER, Max. Direito Privado Romano. Tradução de Samuel Rodrigues e Ferdinand Hämmerle e revisão de Maria Armanda de Saint Maurice. Lisboa: Fundação Calouste Gulbenkian, 1999. p. 428, 456 e 471. Na doutrina nacional, CRUZ E TUCCI e AZEVEDO falam em oralidade no mesmo sentido a que se referiu KASER, ou seja, em termos de prevalência da forma oral sobre a escrita, sem imprimir qualquer conotação moderna a este princípio. AZEVEDO, Luiz Carlos; CRUZ E TUCCI, José Rogério. Lições de História do Processo Civil Romano. São Paulo, Revista dos Tribunais, 2001. p. 53 e 56. SURGIK, na mesma linha, faz apenas referência ao modo oral do desenvolvimento do processo, sem mencionar a concepção moderna acerca do princípio. SURGIK, Aloísio. Lineamentos do Processo Civil Romano. Curitiba: Livro é Cultura, 1990. p. 25. 
Todavia, fazer a mesma afirmação apontando os valores que a doutrina atual considera como inerentes ao processo oral, aduzindo que os romanos teriam vantagens em organizar o processo nestes moldes, significaria atribuir ao homem antigo a consciência de uma construção dogmática tipicamente contemporânea. METZGER, discorrendo especificamente sobre o princípio da oralidade, afirma que, deste modo, the reader is left thinking that the Romans were mindful of this principle and its advantages, rather than, e.g., some combination of illiteracy, time limitations, available methods of writing and duplication, etc. ${ }^{6}$

Ou seja, pode-se afirmar que o processo civil romano, sobretudo no período das ações da lei e no período formular, e em menor intensidade sob o regime da cognição extraordinária, era caracterizado pela oralidade. Contudo, o que não pode ser admitido numa análise histórica é supor que este modo de organização era determinado pelas mesmas razões pelas quais atualmente se adota a oralidade no processo.

Neste estudo procurar-se-á demonstrar como a imediação, a concentração e a oralidade no período do ordo iudiciorum privatorum são explicadas pela peculiar concepção que o homem antigo tinha do fenômeno processual, não guardando nenhuma similitude com a concepção contemporânea de processo oral. Ainda, procurarse-á abordar como estes elementos começaram a se esvaecer gradualmente sob o regime da cognição extraordinária na medida em que se consolida um processo de viés notadamente público.

\subsection{SIGNIFICADO DA ORALIDADE NO PROCESSO CIVIL ROMANO DE ÉPOCA ARCAICA}

Para se compreender adequadamente o processo romano de época primitiva, é necessário tentar compreender a mentalidade do homem místico-religioso. Em outras palavras, é preciso imaginar uma sociedade inteiramente voltada para o misticismo, na qual todos os acontecimentos (tantos os naturais quanto os sociais) eram explicados por meio da religião.

6 METZGER, Ernest. Roman Judges, Case Law, and Principles of Procedure, p. 265. 
Todavia, essa tarefa não é tão fácil. Como observa KASER, a questão sobre a origem das diversas divindades e suas manifestações, assim como o pensamento religioso do homem antigo, permanece em grande parte um mistério para a historiografia. ${ }^{7}$ Assim, as assertivas aqui formuladas devem ser entendidas como meras conjecturas, hipóteses traçadas com base nas poucas fontes existentes sobre esse período.

LÉVY-BRUHL aduz que o primeiro mecanismo existente em Roma de resolução de conflitos que não se fundava na violência foi a Sacramentum arcaica $^{8}$.É plausível supor que este mecanismo não se fundava numa lei, tal como ocorreu com a legis actio per sacramento de época clássica, mas sim em costumes imemoriais, que provavelmente datam dos primórdios da urbe romana ${ }^{9}$.

Como sintetiza RUBENS DE MORAES, a sacramento de época antiga mais se aproximaria de uma forma de juramento assertório, condicionada a uma consulta aos deuses, tendo como conseqüência uma auto-sujeição em caso de perjúrio. ${ }^{10} \mathrm{~A}$ parte que tivesse o seu juramento considerado injustum era considerada um homo sacer.

A condição de sacer esto é imprecisa, como bem aponta ROBERTO FIORI em monografia sobre o tema. Trata-se de uma sanção que gravita entre a esfera religiosa e a jurídica e que em época mais retraída importava penas gravíssimas, de modo que a história dessa penalidade, com seu progressivo abrandamento, confunde-se com o próprio processo de laicização do direito. ${ }^{11}$

Assim, tendo em vista o papel absolutamente central que a religião desempenhava no mundo antigo e o prestígio que o sacerdote gozava nestas comunidades, é razoável supor que a parte vencida não recalcitraria de modo algum em acolher o resultado do julgamento, o que explicaria a inexistência de vias executivas em época tão remota. Neste aspecto, vale notar que quando se afirma que a manus iniectio é mais antiga que a própria sacramentum, quer se referir à manus iniectio em seu sentido literal, de lançar as mãos sobre o devedor como forma de justiça de mão própria. De fato, a legis

KASER, Max. Das Altrömische ius: Studien zur Rechtsvorstellung und Rechtsgeschichte der Römer. Göttingen: Vandenhoeck \&Ruprecht, 1949. p. 302.

8 LEVY-BRUHL, Henri. Recherches sur les Actions de la Loi. Paris: Sirey, 1960. p. 25-26.

9 LEVY-BRUHL, Henri. Recherches sur les Actions de la Loi, p. 25.

10 MORAES, José Rubens de. Sociedade e Verdade - Evolução Histórica da Prova. Tese (Doutorado) Faculdade de Direito da Universidade de São Paulo, 2008. p. 73.

11 La storia del sacer esto non è semplicemente la storia di una pena. É la storia del graduale processo di distinzione tra regole giuridiche e regole religiose. FIORI, Roberto. Homo sacer: dinamica politico costituzionale di una sanzione giuridico-religiosa. Napoli: Jovene, 1996. p. 507. 
actio per manus iniectionem, como medida tendente ao cumprimento de uma sentença, pressupõe uma relativa laicização do processo, e apenas poderia ter surgido em época posterior.

No período em que a monarquia romana era ainda muito rudimentar, esse processo provavelmente era desenvolvido completamente perante o próprio rex, o chefe das gens, sem qualquer delegação de atividade ou bipartição de instâncias. Afirma LÉVY-BRUHL que c'est donc sur sa double qualité de chef d'Etat et de prête supreme que se fonde la competènce exclusive $d u$ roi ${ }^{12}$, devendo-se ler o termo chef d'Etat com todas as aspas que esta expressão merece em época tão remota.

CARRELLI bem observa que neste período mais retraído do história romana não se pode falar de modo algum em exercício de função pública pelos sacerdotes, pois estes exerciam uma atividade estritamente privada. A própria manutenção em segredo das fórmulas sagradas, até a sua publicação por Gneus Flavius em 304 a.C., corrobora a tese da ausência de qualquer conotação pública do processo nesse período. ${ }^{13}$

Aliás, nem mesmo a publicação das fórmulas autorizaria a falar num processo com viés público, pois a atividade exercida pelos sacerdotes perante as partes manteve o seu caráter essencialmente privado. Demais disto, a repercussão dessa publicação, levada a efeito por Gneus Flavius, não pode ser superestimada, porquanto continha apenas os elementos abstratos das fórmulas - as quais deviam ser adaptadas a cada caso concreto -, e a isso se acrescenta a dificuldade de consultá-las numa sociedade de poucos letrados. ${ }^{14}$

Impende destacar que o traço fundamental da Sacramentum de época arcaica é o desenvolvimento do processo num plano completamente místico, sem qualquer discussão sobre os fatos que, numa acepção moderna, seriam relevantes para o deslinde da causa. ${ }^{15} \mathrm{O}$ resultado do processo dependia da regular observância das palavras e gestos rituais, não sendo discutido em nenhum momento qual das partes teria razão, pois o que se discutia não era o direito, mas a honradez e a credibilidade dos litigantes ${ }^{16}$.

12 LEVY-BRUHL, Henri. Recherches sur les Actions de la Loi, p. 28-33. Na doutrina nacional, MEIRA, Sílvio Augusto de Bastos. Noções Gerais de Processo Civil Romano. Roma: Tripi \& Di Maria, 1963. p. 6.

13 CARRELLI, Odorardo. La genesi del procedimento formulare. Milano: Giuffrè, 1946. p. 185.

14 CARRELLI, Odorardo. La genesi del procedimento formulare. Milano: Giuffrè, 1946. p. 187-188.

15 LEVY-BRUHL, Henri. Recherches sur les Actions de la Loi, p. 76.

16 LEVY-BRUHL, Henri. Recherches sur les Actions de la Loi, p. 60. 
O processo antigo era uma luta - não física tampouco jurídica, mas social - entre duas pessoas. Sortira victerieux de ce combat celui qui a su inspirer le plus de crédit, qui aura montré le plus de prestige. ${ }^{17}$ Nesta linha de raciocínio, é compreensível que as partes não poderiam ser representadas em juízo por terceiros, pois o comparecimento pessoal das partes é essencial na concepção mágico-transcendental do processo no mundo antigo.

Aqui vale notar que a obrigatoriedade de comparecimento pessoal das partes nesta fase primitiva de Roma em nada tem a ver com a concepção moderna de imediação entre partes e juiz no sistema da oralidade. A ratio essendi é notadamente diversa. Na Sacramentum arcaica as partes deveriam se apresentar pessoalmente perante a autoridade religiosa por razões que transcendem a racionalidade moderna. Como bem afirma MADEIRA, a arte da defesa [a advocacia] não pode vingar enquanto o direito se confunde com a religião. ${ }^{18}$ Tanto isso é verdade que a possibilidade de representação em juízo apenas surgiu na Roma republicana, quando o processo já havia perdido muito do seu conteúdo sagrado. Aliás, a tese da festuca como simulacro de arma vem a corroborar essa linha de raciocínio.

Portanto, as palavras sagradas pronunciadas pelas partes, assim como os gestos rituais, guardam uma lógica própria, que em nada se assemelham à exposição imediata dos fatos no sistema da oralidade.

\subsection{A ORALIDADE DESVINCULADA DA PROVA NO PERÍODO DAS AÇÕES DA LEI: O PROCESSO CIVIL COMO DISPUTA RETÓRICA E A INEXISTÊNCIA DE UMA TEORIA DA PROVA}

O princípio da oralidade, estreitamente relacionado com a teoria da prova, pode ser entendido como o prestígio da produção oral da prova, partindo-se da premissa de que a discussão oral dos fatos permite que o julgador tenha uma melhor percepção da verdade.

17 LEVY-BRUHL, Henri. Recherches sur les Actions de la Loi, p. 123.

18 MADEIRA, Hélcio Maciel França. História da Advocacia: origens da profissão de advogado no direito romano. São Paulo: Revista dos Tribunais, 2002. p. 28. 
Assim, admitindo-se a tese de inexistência ou incompletude de uma teoria da prova no início do período clássico, e a pertinência da prova ao campo retórico, e não ao jurídico ${ }^{19}$, não é possível falar em plenitude do princípio da oralidade no processo civil dessa época, tal como pretendia CHIOVENDA.

A oralidade no período das ações da lei deve ser entendida como uma oralidade ritualística, de um processo em vias de laicização, no contexto de uma sociedade na qual a cultura escrita ainda não encontrava ampla difusão, de modo que não guarda nenhuma relação com a prevalência da forma oral no sistema contemporâneo da oralidade. Embora seja afirmação corrente que a Lei das XII Tábuas representaria um marco identificador na laicização do processo romano, vale destacar a ressalva feita por RUBENS DE MORAES no sentido de que diversos institutos processuais, notadamente no plano do direito probatório, mantêm sua essência no plano da religião. ${ }^{20}$

Os títulos recolhidos no Digesto de época clássica sobre a prova (D.22.3 a 22.5) não são suficientes para compor uma teoria. Tanto é assim que os jurisconsultos clássicos não examinaram a questão da prova, tendo dado atenção para a discussão do direito aplicável, negligenciando a apuração dos fatos no processo. ${ }^{21}$

Quanto à famosa regra ei incumbit probatio qui dicit, non qui negat, atribuída ao jurista clássico Paulo, recolhida em D.22.3.21, suspeita-se que originalmente essa regra dizia respeito apenas a alguns casos particulares, e não exprimia uma regra jurídica no âmbito probatório, mas antes uma constatação empírica diante de situações específicas. ${ }^{22} \mathrm{Na}$ mesma linha, SURGIK sustenta que tal regra teria sido interpolada. $^{23}$

Deveras, essa interpretação resolve a aparente incoerência existente entre a regra atribuída ao jurista Paulo e a narrativa de Aulo Gélio no Capítulo II, Livro XIV, das Noites Áticas. A perplexidade de Gélio sobre como proceder no julgamento diante de uma situação fática não esclarecida de modo suficiente é incompatível com a existência já em época clássica de uma regra bem delineada sobre o ônus da prova, tal como aquele contida em D.22.3.21.

19 LEVY, Jean Phillipe. La formation de la théorie romaine des preuves. In: Studi in Onore di Siro Solazzi. Napoli: Jovene, 1948. p. 419-420. MORAES, José Rubens de. Sociedade e Verdade, p. 114-131.

20 MORAES, José Rubens de. Sociedade e Verdade, p . 80.

21 LEVY, Jean Phillipe. La formation de la théorie romaine des preuves, p. 422.

22 TOZZI, Antonio. L'evoluzione del giudizio di fatto nel processo romano. Rivista di Diritto Processuale, Padova, Cedam, Parte I, V. XVII, 1940. p. 139.

${ }_{23}$ SURGIK, Aloísio. Lineamentos do Processo Civil Romano, p. 69-70. 
A tese da interpolação da referida regra também ganha força se se pensar que o iudex, ainda que membro de um grupo social privilegiado, não deixa de ser um cidadão romano como qualquer outro, podendo, diante da incerteza, sentenciar sibi non liquere. Ora, regras de ônus da prova - que servem para guiar o julgador na ausência de provas com o intuito de possibilitar que este forme sua convicção de forma segura apenas fazem sentido num sistema em que é vedado o non liquet.

Assim, a tese mais convincente é aquela que sustenta ser a matéria da prova assunto afeto ao campo da retórica. Como bem afirma JEAN PHILIPPE LEVY, a melhor obra sobre provas em época clássica é a Institutio Oratoria de Quintiliano. ${ }^{24}$ Como assevera o autor, apesar da existência no processo romano clássico das principais modalidades de prova, e de regramento acerca de impedimentos e suspeições no que se refere à prova testemunhal, bem como de outras regras específicas ligadas à produção da prova, não é possível afirmar a existência de uma teoria da prova nesse período, pois foi somente no Baixo Império que esta começou a ser delineada com maior clareza. ${ }^{25}$

Neste contexto, não se pode falar em oralidade na sua significação relacionada à livre apreciação da prova, porquanto a assunção e a valoração dos fatos ainda não eram pautadas por critérios racionais. A oralidade na discussão dos fatos, determinada nessa época por fatores extrínsecos e casuais, como já afirmado, não oferecia nenhum benefício para o âmbito da prova no período das ações da lei, dada a pertinência da prova ao campo da retórica; ao contrário, permitia a manipulação do convencimento do juiz acerca dos fatos por artifícios retóricos.

\subsection{CONCENTRAÇÃO PROCEDIMENTAL E VARIAÇÕES INTERPRETATIVAS DA REGRA SOLIS ACCASUS SUPREMA TEMPESTAS ESTO}

A regra 11 da tábua primeira da Lei das XII Tábuas estabelece a regra solis accasus suprema tempestas esto. Esta regra foi reconstruída partindo-se de

24 LEVY, Jean Phillipe. La formation de la théorie romaine des preuves, p. 424.

25 LEVY, Jean Phillipe. La formation de la théorie romaine des preuves, p. 419-420 e 424 . No mesmo sentido, TOZZI, Antonio. L'evoluzione del giudizio di fatto nel processo romano. Rivista di Diritto Processuale, Padova, Cedam, Parte I, V. XVII, 1940. p. 138. 
obras literárias, tais como a de Macróbio (Saturnalia, Livro I, Capítulo 3), que cita esta regra ao discorrer sobre a divisão do dia civil em Roma ${ }^{26}$.

Em linhas gerais, pode-se afirmar que duas interpretações firmaram-se em relação a este dispositivo. A primeira aduz que a regra determinava que a audiência deveria ter fim até o pôr do sol, de modo que a discussão da causa e os atos instrutórios deviam ser realizados de modo concentrado em um único dia.

Neste sentido, JULIUS BARON sustenta que o procedimento deveria se desenvolver de modo completo em um único dia, de forma que o juiz pudesse julgar tendo a discussão ainda fresca em sua memória. ${ }^{27}$ Essa linha de interpretação leva às últimas consequências a expressão suprema tempestas contida na regra.

Por outro lado, uma segunda linha, de uma historiografia mais recente - e mais plausível -, sustenta que a regra apenas delimitaria o período do dia em que a audiência poderia se desenvolver, não havendo impedimento para que, não tendo sido concluídos todos os trabalhos em um único dia, estes tivessem continuidade no dia seguinte. $^{28}$

${ }^{26}$ Neste capítulo, Macróbio discorre sobre o marco para a contagem dos dias, assim como os períodos de cada dia. Narra o autor que cada povo da antiguidade adotava critério diverso para a contagem dos dias: na Babilônia era a aurora, em Atenas era o pôr do sol, e em Roma a meia-noite. Para fins de ritos religiosos, assim com para as audiências (daí a citação da Lei das XII Tábuas), dividia-se o dia em período diurno e noturno, assim como antes e após o meio-dia.

${ }_{27}$ Die gesammte verhandlung must auch jetzt en Einem Tage durchgefuhrt werden, damit bei dem Mangel schriftlicher Aufzeichung das Urteil unter dem frischen Eindruck des Gehorten ergehe; ist dies nicht moglich, so wird vom Geschworenen die Ampliatio ausgesprochen und in einem neuen Termin von Neuen begonnen, namentlich das tatsachliche Material nochmals entwickelt. BARON, Julius. Geschichte des römischen Rechts: Institutionen und Civilprozess, Berlin: Simion, 1884. p. 425 apud METZGER, Ernest. Roman Judges, Case Law, and Principles of Procedure, nota 116. Em tradução livre, "Agora, o procedimento deve ser conduzido em sua totalidade dentro de um dia, de modo que, diante da ausência de registros escritos, o julgamento possa ser proferido com base em impressões ainda vivas extraídas das manifestações das partes. Não sendo isto possível, o júri pode evocar a Ampliatio, marcando uma nova data para se reiniciar o procedimento desde o início, vale dizer, para que os envolvidos produzam e apresentem mais uma vez todo o material probatório aos julgadores”. POTHIER anota que o pôr do sol é o término da função judicial (solis occasus, supremus sit terminus exercendum judiciorum), mas não discute se haveria possibilidade de a audiência prosseguir no dia seguinte. POTHIER, Robert Joseph. Pandectae Justiniane, in novum ordinem digestae, cum legibus, codicis, et novellis, que jus pandectarum confirmant, explicant, aut abrogant. Tomus Primus. Paris: Fournier, 1818. p. 77.

28 METZGER inclina-se pela inexistência de limitação da audiência a um único dia com base na Lei das XII Tábuas. METZGER, Ernest. Roman Judges, Case Law, and Principles of Procedure, p. 267-268. No mesmo sentido, JOLOWICZ, The hearing had to come to an end at sunset, but, at any rate, in later times, when advocates had learnt to make long speeches, adjournments were common in important cases. JOLOWICZ, Herbert Felix. Historical Introduction to the Study Roman Law. Cambridge: Cambridge University, 1952. p. 188. Na doutrina nacional, SILVIO MEIRA não exclui a possibilidade de a audiência ter continuidade no dia seguinte, MEIRA, Sílvio Augusto de Bastos. Noções Gerais de Processo Civil Romano, p. 26. LÉVY-BRUHL não esclarece expressamente se a audiência poderia ou não continuar no dia seguinte, mas afirma que a regra se destina a delimitar o momento do dia em que o juiz poderia exercer suas atividades. LEVY-BRUHL, Henri. Recherches sur les Actions de la Loi, p. 207. KASER admite 
Cícero (Pro Publius Quinctio, IX e X) relata um caso no qual a peroratio do patrono da parte contrária teria se alongado por muito tempo, nunca chegando a conclusão alguma (priore patrono causam defendente numquam perorari potuisse), levando-o a expor brevemente seus próprios argumentos. Infelizmente, o orador não deixa claro se procedeu desta forma pensando estrategicamente na defesa, optando por não entediar o julgador, ou, se o desfecho da audiência deveria ocorrer obrigatoriamente no mesmo dia, sem que fossem possíveis prorrogações.

Em todo caso, admitindo-se ou não a prorrogação da audiência para o dia seguinte, é inegável que o processo no ordo iudiciorum privatorum era concentrado em poucos atos. Assim, mesmo considerando o lapso de tempo necessário entre a nomeação do iudex pelo pretor e o julgamento perante este, é inegável a concentração do procedimento.

Não obstante, não existem evidências de que esta concentração fosse estimulada ou particularmente valorizada, tal como ocorre nos sistemas processuais modernos; ao contrário disso, constituía um dado casual no contexto de processo desenvolvido perante um julgador privado e de uma sociedade de desenvolvimento econômico ainda incipiente. Ou seja, a concentração do processo provavelmente decorria de fatores extrínsecos, tais como a provável baixa complexidade dos litígios, o número não expressivo de conflitos, disponibilidade de tempo dos julgadores e partes, etc.

Afirmar que a concentração procedimental no processo do ordo iudiciorum privatorum estaria de algum modo atrelada ao princípio da oralidade importaria em atribuir ao homem de época clássica uma preocupação quanto à duração do processo que apenas surgiria no período da extroardinaria cognitio. A concentração, tal como a oralidade, era uma característica casual do processo civil romano, não guardando em si qualquer valor intrínseco. Tanto é assim, que no período da extraordinaria cognitio, tal característica é praticamente abandonada em virtude da burocratização da atividade judicante.

expressamente a possibilidade de um aditamento da audiência no dia seguinte. KASER, Max. Direito Privado Roman, p. 455-456. 


\title{
2.4 A NATUREZA PÚBLICA DO PROCESSO COMO PRESSUPOSTO DO SISTEMA DA ORALIDADE
}

\begin{abstract}
Admitindo-se as origens sacras do processo romano, mostra-se inadmissível qualquer comparação do processo do ordo iudiciorum privatorum com a arbitragem. A função do iudex não era inteiramente privada ${ }^{29}$ - sua atividade derivava de um múnus que outrora era revestido de caráter religioso, sendo, tal como a atividade dos sacerdotes em época remota, essencial para a preservação da paz social na sociedade romana.
\end{abstract}

Por outro lado, pensar no iudex como um representante do Estado no exercício de uma função pública significa deixar de lado importantes considerações metodológicas da pesquisa histórica para imprimir um viés notadamente contemporâneo a um fenômeno da Antiguidade.

Nesta mesma linha, CHIOVENDA afirma que a iurisdictio é uma função pública, mesmo no período clássico, e não mera prerrogativa pessoal do juiz: potere pubblico, derivato dalla sovranità ed esclusivamente da questa, imperio esercitato come un dovere in rappresentanza dello Stato da organi di questo (...). ${ }^{30}$

Ora, ainda que se admita a tese de que as partes não poderiam nomear como iudex alguém cujo nome não estivesse previsto no album judicum, de modo que ser nomeado iudex era efetivamente um privilégio de senadores e membros da classe equestre, é inadmissível pensar a existência de um poder público em Roma com a carga conceitual que tal expressão possui hoje. Demais disso, como assevera SURGIK, a utilização da palavra Estado para descrever uma organização política anterior ao século XIII é um anacronismo em sua própria essência, inadmissível no plano da pesquisa histórica. ${ }^{31} \mathrm{O}$ mesmo ocorre com o conceito de soberania, que, somente poderia ser utilizado para descrever um fenômeno da Antiguidade se despido do significado que tal termo adquiriu após a Paz de Westfália, em 1648.

Eram de fato particulares os incumbidos do munus judicandi em todo período do ordo judiciorum privatorum. O único personagem que poderia ser

29 LEVY-BRUHL, Henri. Recherches sur les Actions de la Loi, p. 204.

30 CHIOVENVA, Giuseppe. L'idea romana nel processo civile moderno. In: Saggi di Diritto Processuale. v. 3. Milano: Giuffrè, 1993. p. 79.

31 SURGIK, Aloísio. Lineamentos do Processo Civil Romano, p. 15, nota 8. 
considerado detentor de um múnus público era o pretor, mas este não exercia a jurisdictio. A circunstância de apenas senadores, e, em determinada época - em razão da Lex Sempronia -, membros da classe equestre, poderem figurar no album judicum denota apenas uma prerrogativa aristocrática, e não um viés precocemente público do processo romano.

Deveras, é apenas a partir das profundas reformas promovidas por Otaviano Augusto, já sob o regime da extraordinaria cognitio, que se pode falar em processo de caráter público em Roma, com a burocratização e a hierarquização da atividade judicante.

É claro que categorizar o processo do ordo iudiciorum privatorum como essencialmente privado, e aquele do período da extraordinaria cognitio como público, em certa medida, não deixa de ser também um anacronismo - considerando-se que esta dicotomia apenas passa a ser central no pensamento jurídico a partir da modernidade -, mas este expediente é válido desde que utilizado como um instrumental para melhor compreensão do fenômeno estudado. Como afirma METZGER, o problema não é o uso destes anacronismos em si, mas sim a explicação de fenômenos passados atribuindo estado de espírito moderno aos atores, pois assim estariam sendo feitas conexões espúrias entre as ações humanas e os eventos explicados. ${ }^{32}$

Assim, ao se definir o processo do período da extraordinaria cognitio como público, o objetivo é afirmar a burocratização da atividade judicante, a hierarquização da magistratura, tendo em seu ápice o próprio princeps, a proibição de o juiz sentenciar sibi non liquere, o acesso às vias recursais e o surgimento de poderes formais de direção do juiz sobre o processo, em contraposição ao processo do ordo iudiciorum privatorum.

Este último aspecto - a existência de poderes formais de direção do processo pelo juiz - interessa particularmente ao estudo da oralidade no processo civil romano. CARRELLI, discorrendo sobre o processo perante o pretor urbano no período clássico, sustenta que a iniciativa processual era completamente atribuída às partes, cabendo ao magistrado exercer um controle meramente passivo da regularidade formal do processo. Em sentido semelhante, METZGER afirma que roman litigation in the classical

32 METZGER, Ernest. Roman Judges, Case Law, and Principles of Procedure, p. 247. 
period combined private initiative with modest pubic oversight. ${ }^{33}$ Ou seja, pode-se afirmar que haveria, em época clássica, uma completa, ou quase completa, ausência daquilo que hoje denominamos poderes de direção do juiz, tanto em seu aspecto formal, quanto material.

Esse estado do processo apenas começou a se alterar num momento posterior à Lex Aebutia (149-126 a.C.), quando o pretor peregrino e, posteriormente, também o pretor urbano, com base no poder de imperium, passaram a adaptar fórmulas existentes para situações não expressamente contempladas, ou, até mesmo, a conceder fórmulas que nem eram previstas no edito. Este fenômeno indica que nessa época o processo romano iniciou um lento processo de transformação de um sistema de ações para um sistema de direitos, assim como denota o surgimento de alguns poderes do pretor na direção do processo, importando no surgimento de elementos públicos no âmbito de um processo que até então era marcado por acentuado viés privado.

Assim, o processo do período formular seria ainda notadamente privado, porquanto os principais protagonistas do processo seriam as partes, o que é corroborado pela tese de WLASSAK sobre a natureza contratual da litiscontestatio ${ }^{34}$, assim como pela relativa liberdade das partes na escolha do iudex. Por outro lado, conforme sustenta CARRELLI, o elemento público do processo surgiu com a atividade criativa do pretor, que, ao conceder fórmulas não previstas no edito, estaria ele próprio, juntamente com as partes, fixando os pontos a serem decididos pelo iudex, superando a postura completamente passiva de outrora. ${ }^{35}$

É interessante notar que, na visão de CAPPELLETTI, a oralidade possui um significado primário consistente na livre apreciação da prova testemunhal. Considerando este primeiro significado, afirma o autor que o processo romano clássico era coerente com a oralidade nesta acepção, pois o iusiurandum da fase apud iudicem assumia

33 METZGER, Ernest. Litigation in Roman Law. New York: Oxford University, 2008. p. 3.

34 Segundo WLASSAK a liticontestatio seria ein das Verfahren in iure abschliessender Formalvertrag bei dem es sich um die Prozessurkunde, die Schriftformel drehte. Em tradução livre, um contrato formal cujo efeito jurídico consistia em atestar a vontade das partes, no que dizia respeito ao fundamento da obrigação que ensejara o processo. Cf. Die Litiskontestation im Formularprozess, in Breslauer Festschrift für Bernhard Windscheid. Leipzig: Duncker \& Humblot, 1889. p. 12, n. 15, citado por CARRELLI, que esclarece que na acepção de WLASSAK, a litiscontestatio serviria para consagrar a vontade concordantes das partes, sobre o fundamento da obrigação processual. CARRELLI, Odorardo. La genesi del procedimento formulare. Milano: Giuffrè, 1946. p. 17-18.

35 L'effetto precipuo della riforma ebuziana fu quindi di introdurre nel vecchio processo civile un elemento pubblicistico, il decretum di istruzione del magistrato, decretum che fra l'altro, come tale, il magistrato poteva ache rifiutare (denegatio actiones). CARRELLI, Odorardo. La genesi del procedimento formulare. Milano: Giuffrè, 1946. p. 235. No mesmo sentido, p. 114. 
o caráter de prova livre ${ }^{36}$. Já o mesmo não poderia ser afirmado em relação ao processo da extraordinaria cognitio a partir do Baixo Império, devido à introdução de elementos de prova tarifada no direito probatório.

A oralidade em seu sentido secundário - de acordo com o pensamento de CAPPELLETTI - deve ser entendida come possibilità che il giudice esiga "chiarificazione" orale delle allegazioni e in genere delle domande, pressupondo necessariamente um processo de caráter público. ${ }^{37}$ Assim, neste aspecto, somente seria possível falar em oralidade no processo romano em época pós-clássica.

Deste modo, adotando-se a definição de oralidade de CAPPELLETTI, chega-se à conclusão de que o processo do ordo iudiciorum privatorum, mais especificamente o processo do período formular, conheceu a oralidade em sua significação primária (livre apreciação da prova), em razão do iusiurandum na fase apud iudicem, mas não em seu sentido secundário, uma vez ausente um de seus pressupostos, qual seja, a existência de poderes de direção do processo pelo juiz. Já durante o principado, teria existido a oralidade tanto no sentido primário de livre apreciação da prova, como no secundário de possibilidade de exigência de esclarecimentos orais (interrogatório ad clarificandum $^{38}$ ). Por fim, no dominato, esta primeira significação teria desaparecido paulatinamente, dada a introdução de elementos de prova legal no sistema.

Outro aspecto de relevo é que a publicidade da audiência, prevalente em todo período do ordo iudiciorum privatorum, foi paulatinamente abandonada no período da cognição extraordinária. A audiência passou a ser realizada no secretarium, sala a que somente as partes, seus advogados, o juiz e seus assistentes tinham acesso. ${ }^{39}$ Esta transformação, corroborando o leitmotiv deste trabalho, demonstra que a publicidade da audiência, hoje vista como uma garantia fundamental das partes, era uma característica casual do sistema no processo civil romano. É o que ocorre com a própria prevalência da forma oral do processo, que, em razão da burocratização da atividade judicante, cedeu lugar, em época imperial, ao processo escrito. ${ }^{40}$

36 CAPPELLETTI, Mauro. La testimonianza della parte nel sistema dell'oralità - Contributo alla teoria della utilizzazione probatoria nel sapere delle parti ne processo civile. Parte Prima. Milano: Giuffrè, 1974. p 212.

37 CAPPELLETTI, Mauro. La testimonianza della parte nel sistema dell'oralità, p. 69.

38 Ulpiano (D. 11..1.21) Ubicumque iudicem aequitas moverit, aeque oportere fieri interrogationem dubium non est.

39 SURGIK, Aloísio. Lineamentos do Processo Civil Romano, p. 121.

40 SURGIK, Aloísio. Lineamentos do Processo Civil Romano, p. 121. 


\subsection{PROVA LEGAL NO BAIXO IMPÉRIO}

Ultrapassada a fase da prova essencialmente ligada ao campo retórico, próprio do período das ações da lei, vigorou no período formular o princípio da livre convicção do juiz. Todavia, na passagem do Alto para o Baixo Império surgiram os primeiros elementos relacionados ao sistema da prova legal.

Sustentar a existência de limitações ao livre convencimento do juiz antes desse período seria interpretar equivocadamente artifícios de retórica relatados pelos grandes oradores de época clássica como regras de valoração da prova. Neste sentido, ANTONINO METRO sustenta que não é correto afirmar que Sêneca (4 a.C. - 65 d.C.) em De Beneficis 6.8.4 e em Controversiae 7.5.4 já aludia à regra unus testis nullus testis, porquanto nestas passagens o autor não questionava a admissibilidade da prova, mas sim a sua credibilidade, numa perspectiva retórica. ${ }^{41}$

No plano das fontes jurídicas, ANTONINO METRO defende que não se pode afirmar que a passagem D. $22.5 .12^{42}$ de Ulpiano confirmaria que a regra unus testis nullus testis seria de época clássica. Sustenta o autor que a palingenésia do fragmento revela que a regra apontada por Ulpiano apenas estabelecia que a inspeção domiciliar, no caso específico de furtum conceptum, deveria ser realizada na presença de ao menos duas testemunhas. ${ }^{43}$

Foi somente na passagem do Alto para o Baixo Império que surgiram os primeiros elementos do sistema da prova legal no processo romano. $\mathrm{O}$ imperador Marco Aurélio Severo Alexandre, que viveu entre 208 e 235 d.C. e foi imperador entre 222 e 235 determinou em 222 d.C. que para se provar a propriedade eram necessários outros elementos de prova além do instrumento de compra e venda (instrumento emptionis). ${ }^{44} \mathrm{O}$ imperador Marco Júlio Felipe, também conhecido como Felipe, o Árabe, que viveu entre 204 e 249 d. C. e foi imperador entre 244 e 249,

41 METRO, Antonino. Unus testis nullus testis. In: CAIRNS, John; ROBINSON, Olivia (Org.). Critical Studies in Ancient Law.Comparative Law and Legal History. Hart: Antwerp, 2001. p. 110-111.

42 Ubi numerus testium non adicitur, etiam duo sufficient: pluralis enim elocutio duorum numero contenta est.

43 METRO, Antonino. Unus testis nullus testis, p. 111.

44 C.4.19.4 Proprietatis dominium non tantum instrumento emptionis, sed ex quibuscumque aliis legitimis probationibus ostenditur. 
determinou em 245 d.C. que o documento particular por si só não seria suficiente para fazer prova, se desacompanhada de outros elementos. ${ }^{45}$

Uma constituição de Constantino, datada do ano de 334 d.C., afirmou a famosa regra unus testis nullus testis em termos genéricos, marcando a introdução de uma expressiva limitação da prova oral no processo civil da época do dominato.

Mas não se pode interpretar a introdução destes elementos de prova legal no sistema processual do Baixo Império como um simples retrocesso. O sistema de prova legal surgiu como uma resposta de moralização do processo frente à crise da administração da justiça, inserida num contexto mais amplo de desestruturação do próprio império. Assim, o surgimento da prova legal, ao invés de representar propriamente um retrocesso, pode ser visto como uma garantia de imparcialidade do juiz no contexto de uma sociedade que progressivamente testemunhava o desmoronamento de suas instituições.

Em linhas gerais, é interessante destacar a posição mediana de GEHARD WALTER, que conclui que o processo pós-clássico gravitava entre o sistema da livre apreciação das provas e o da prova legal, não sendo possível afirmar peremptoriamente a existência de regras vinculantes predeterminando de forma absoluta o valor de cada meio de prova, assim como não se pode negar a existência de alguma liberdade do juiz na formação de sua convicção, mesmo diante de tantos elementos de prova tarifada. ${ }^{46}$

\subsection{IRRECORRIBILIDADE DAS INTERLOCUTIONES}

Interlocutio significa ação de interloquere. No latim clássico, tanto o vocábulo interlocutio como o interloquere não pertenciam ao campo semântico jurídico, mas sim ao da comunicação oral, significando interpelação, interrupção de uma conversa. $^{47}$

45 C.4.19.5 Instrumenta domestica seu privata testatio seu adnotatio, si non aliis quoque adminiculis adiuventur, ad probationem sola non sufficiunt.

46 WALTER, Gerhard. Libre Apreciación de La Prueba, Investigación acerca del significado, las condiciones y límites del libre convencimiento judicial. Tradução de Tomás Banzhaf. Bogotá: Temis, 1985. p. $19-20$.

47 MORENO RESANO, Esteban. La acepción de interlocutio en derecho romano. Revue Internationale des Droits de l'Antiquité, $3^{\mathrm{e}}$ Série, t. L, 2003. p. 254. 
No plano do direito, o termo interlocutio surgiu nas fontes sendo empregado com dois sentidos distintos. O menos recorrente aponta para um gênero normativo, uma espécie de constituição imperial próxima aos rescripta, com a diferença de que não seria expresso pelo imperador de modo escrito, mas sim reduzido a escrito em momento posterior. A segunda acepção, que interessa ao presente estudo, indica um ato processual, consistente num pronunciamento do juiz que se contrapunha aos provimentos cognita causa, não ficando abrangidos pela res iudicata. ${ }^{48}$

Não existe uma definição precisa do conteúdo da interlocutio. Nas fontes encontram-se registros de interlocutiones para ordenar a citação, declarar a inadmissibilidade da apelação, fixar a posição de autor e réu, e, principalmente, para dispor sobre atos instrutórios, tais como determinar ou inadmitir a oitiva de testemunhas, autorizar a leitura de documentos, etc. ${ }^{49}$

Quanto ao momento em que a interlocutio era pronunciada, MORENO RESANO aduz que, em tese, nada impediria que este ato fosse posterior à sentença. ${ }^{50}$ Note-se que Aulo Gélio não faz referência à interlocutio como sendo o pronunciamento judicial anterior à sentença, mas o inverso - afirma que o pronunciamento judicial sobre a instrução da causa ante sententiae tempus realizava-se mediante uma interlocutio. ${ }^{51}$ Corroborando esse raciocínio, numa passagem de Paulo verifica-se que o prefectus vigilum poderia suspender a aplicação de uma penalidade física - possivelmente cominada numa sentença - por meio de uma interlocutio. ${ }^{52}$

O ponto mais importante a ser destacado sobre as interlocutiones é que elas não estavam sujeitas à preclusão, o que explica o não cabimento de appellatio em

\footnotetext{
48 MORENO RESANO sustenta que, a rigor, não havia diferenças formais entre estas interlocutiones, pois ambas faziam referência a resoluções judiciais, o que, de certo modo, autoriza a afirmar que ambas possuíam natureza processual. A diferença substancial é que a interlocutio proferida pelo princeps ex imperio tinham força de lei, pelos simples fato de serem originárias de pronunciamentos do imperador (D.1.4.1.1 Quod principi placuit, legis habet vigorem). MORENO RESANO, Esteban. La acepción de interlocutio en derecho romano, p. 256-257.

49 CHIOVENDA, Giuseppe. Sulla influenza delle idee romane nella formazione dei processi civili moderni. In: Saggi di Diritto Processuale Civile. Milano: Giuffrè, 1993. p. 100.

50 MORENO RESANO, Esteban. La acepción de interlocutio en derecho romano, p. 256 e 261.

51 Noites Áticas 14.2.17. Praeter haec super ea quoque re dissentitur, an ex usu exque officio sit iudicis rem causamque, de qua cognoscit, interlocutionibus suis ita exprimere consignareque, ut ante sententiae tempus ex his, quae apud eum in praesens confuse varieque dicuntur, proinde, ut quoquo in loco ac tempore movetur, signa et indicia faciat motus atque sensus sui.

52 D.15.3.1. 1. Cognoscit praefectus vigilum de incendiariis effractoribus furibus raptoribus receptatoribus, nisi si qua tam atrox tamque famosa persona sit, ut praefecto urbi remittatur. Et quia plerumque incendia culpa fiunt inhabitantium, aut fustibus castigat eos qui neglegentius ignem habuerunt, aut severa interlocutione comminatus fustium castigationem remittit.
} 
face desses pronunciamentos ${ }^{53}$. Deveras, CHIOVENDA aponta uma única hipótese de fixação definitiva de pontos por meio de uma interlocutio, que é o caso daquela proferida pelo imperador por meio de uma consulta. ${ }^{54}$

Todavia, nem mesmo esse caso apontado por CHIOVENDA se trata rigorosamente de uma preclusão. A estabilidade decorrente da interlocutio imperial não segue a mesma lógica, tampouco visa aos mesmos fins do regime preclusivo das decisões interlocutórias que surgiria apenas no seio do ius commune e seria levada às últimas consequências no direito canônico. A vinculação do magistrado romano ao que foi fixado numa interlocutio imperial por ocasião de uma consulta é fundada na hierarquia da magistratura romana, que tem em seu ápice o próprio imperador.

A nomenclatura sententia interlocutoria é produto do ius commune. No processo romano, o vocábulo sententia era reservado para o ato final do iudicium, que rejeitava ou acolhia a demanda. Como assevera CHIOVENDA, foi apenas em época posterior, por influência germânica, que a interlocutio passou a ser chamada de sententia interlocutoria, adquirindo das sentenças não apenas o nome e a forma, mas também o regime recursal e a aptidão para transitar em julgado. ${ }^{55}$

A expressão sententia definitiva encontrada de modo recorrente nas fontes romanas não autoriza afirmar a existência de uma sentença não definitiva. CHIOVENDA, com os conceitos que lhe são próprios, afirma que o adjetivo definitiva não é empregado no sentido de última, final, contrapondo-se a interlocutoria, mas em seu significado primeiro, ou seja, sentença como ato que define a lide. ${ }^{56}$

Portanto, verifica-se que o não cabimento de appellatio em face das interlocutiones no processo romano da extraordinaria cognitio estava estritamente relacionado à ausência de preclusão em relação a estes pronunciamentos judiciais. Não é

53 MOACYR LOBO DA COSTA registra que excepcionalmente era admitida appellatio contra uma interlocutio, conforme aponta um fragmento de Scervidius Scaevola (D.49.5.2) e outra de Macer (D.49.5.4), tendo a proibição de se apelar em face das interlocutiones sido afirmada posteriormente por Valentiniano e Valente em 364 d.C. (Cod. Th. 11.36 .15 e 16) e Valente e Graciano em 378 d.C. (11.36.23). LOBO DA COSTA, Moacyr. O Agravo no Direito Lusitano. In: .; AZEVEDO, Luiz Carlos de. Estudos de

História do Processo: Recursos. Osasco: FIEO, 1996. p. 134-135. A excepcionalidade do cabimento de apelação em face de uma decisão interlocutória com base em Scaevola (D.49.5.2) é confirmada na esfera do processo penal por PÖLÖNEN, que anota que o recurso poderia ser manejado para obstar a tortura aplicada de forma contrária à lei antes da sentença. PÖLÖNEN, Janne. Plebeians and Repressions of Crime the in Roman Empire: from the torture of convicts to the torture of suspects. Revue Internationale des Droits de L'Antiquité, t. LI, 2004. p. 227.

54 CHIOVENDA, Giuseppe. Cosa giudicata e preclusione. In: Saggi di Diritto Processuale Civile. v. 3. Milano: Giuffrè, 1993. p. 245.

55 CHIOVENDA, Giuseppe. Cosa giudicata e preclusione, p. 238-239.

56 CHIOVENDA, Giuseppe. Cosa giudicata e preclusione, p. 240. 
possível supor que este regime guardasse qualquer similitude com a questão da irrecorribilidade das decisões interlocutórias no sistema da oralidade.

Um sistema rigoroso de preclusões, que historicamente fomentou a reação no século XIX no sistema da oralidade contra a recorribilidade plena das decisões interlocutórias com efeito suspensivo, apenas surgiria com o processo canônico, no qual o procedimento era minuciosamente e formalisticamente predeterminado, divididos em termini, encerrados por sentenças interlocutórias apeláveis. ${ }^{57}$

\subsection{PROVIMENTOS FUNDADOS EM PROVA SEMIPLENA NO PERÍODO DA EXTRAORDINARIA COGNITIO: SUMARIZAÇÃO DA COGNIÇÃO}

A admissão de decisões provisórias fundadas em provas não plenas ou limitadas (sumarização da cognição) é um fenômeno que surgiu apenas no processo civil romano do Baixo Império, mais especificamente a partir de Diocleciano (244-311 d.C.), como um desdobramento da necessidade de se dar uma solução mais célere, ainda que não definitiva, para determinados litígios. ${ }^{58}$

O estudo sobre as origens do processo sumário nesta acepção não se limita, conforme sustenta BIONDO BIONDI, às fontes nas quais são utilizadas a terminologia summatim cognoscere e summaria cognitio. Em algumas hipóteses, observase apenas uma limitação da cognição e a correlata provisoriedade da decisão, sem que haja qualquer atenuação da solenidade do processo escrito (e.g. actio ad exhibendum).

Noutras, a sumarização da cognição é acompanhada de uma atenuação da regra do processo escrito. Deveras, fontes pouco anteriores a Justiniano (527-565 d.C.) já falam em processo sine scripto. ${ }^{59}$ A importância destas manifestações é

\footnotetext{
57 ATTILIO, Nicora. Il principio di oralità nel diritto processuale civile italiano e nel diritto processuale civile canonico. Series Facultatis Iuris Canonici. Roma: Università Gregoriana, 1977. p. 6.

58 Summatim Cognoscere vuol dire facoltà concessa al giudice di procedere, ai fini della decisione, ad una indagine superficiale, limitata a cio che appare prima facie, diretta alla ricerca del semplice verosimile, $e$ nei casi in cui è amessa espressamente dal legislatore importa una prova non assoluta ma semipiena, in antitesi alla prova piena e legale prescritta in tutti gli altri casi. BIONDI, Biondo. Summatim Cognoscere. Bullettino dell' Istituto di Diritto Romano, ano 30, 1921. p. 256.

59 BIONDI, Biondo. Summatim Cognoscere, p. 232-233 e 257.
} 
que elas serviram de base para o desenvolvimento ulterior da sumarização das formas, sem prejuízo da cognição, na experiência processual canônica dos séculos seguintes.

\subsection{SUMARIZAÇÃO DA FORMA, CLEMENTINA SAEPE E OS PLENÁRIOS RÁPIDOS}

O tema da sumarização do processo envolve duas ordens de fenômenos diversos: (a) a sumarização da cognição, pela admissão de provimentos judiciais provisórios fundados em provas semiplenas, e (b) a sumarização da forma, por meio da simplificação do procedimento, pela supressão de solenidades ínsitas ao procedimento ordinário, sem limitação da cognição. ${ }^{60}$

O primeiro fenômeno, que pressupõe a adoção, ainda que de forma incompleta, do sistema da prova tarifada, não é estranho ao processo civil romano do Baixo Império, conforme demonstrado em tópico acima.

Já o segundo fenômeno, relacionado aos chamados plenários rápidos, marcados pela simplificação da forma, em oposição à solenidade do processo ordinário, é algo posterior ao primeiro fenômeno, sendo produto de um lento desenvolvimento conceitual na experiência processual do mundo ocidental.

Porém, é preciso frisar que a sumarização da forma não é uma ideia que surge ex abrupto. Deveras, Clemente $\mathrm{V}$ não veicula ideias inéditas em sua famosa bula de 1316. Como bem afirma NÖRR, os elementos para o advento de um tipo processual sumarizado e simplificado preexistiam à Clementina Saepe. A bem da verdade, a importância desta bula papal na história do processo ocidental está na seleção e síntese destes elementos para a formação de um modelo processual diferenciado do processo ordinário. $^{61}$

60 Segundo BIONDO BIONDI, processo sumário, na processualística do ius commune, significa um complexo de normas e princípios especiais, baseados na legislação romano-canônica, que convergem para o fim de dar maior celeridade ao andamento do processo, em relação ao processo ordinário, nos limites e hipóteses determinados pela lei, seja através da simplificação das formas solenes, seja pela admissão de juízos fundados em provas não plenas. BIONDI, Biondo. Summatim Cognoscere, p. 220.

${ }_{61}$ Man könnte sogar sagen, dass in der Typisierung im Sinne des Erschaffens einer zusätzlichen Prozessgattung das eigentlich Neue Lag, das durch Saepe in die Welt gesetz worden ist. Denn die Elemente des neuen Typus waren schon vorhanden: das gilt sowohl für die Begriff, die den Anstoss zu einem summarischen Vorgehen gaben, als auch die Prozesshandlungen und Prozessstadien, in welchen sich das summarische vom ordentlichen Verfahren unterschied. Der Innovation bestand demnach in der Auswahl und 
Neste sentido, BIONDO BIONDI afirma que o direito canônico não se sobrepõe ao processo romano. O processo canônico se erige sobre as bases do processo romano, adaptando-o ao seu próprio espírito e às suas próprias exigências. ${ }^{62}$

Todavia, ao contrário do processo civil desenvolvido pelos romanos e pelos povos germânicos, o direito processual civil canônico apresentou desde cedo forte tendência de fazer prevalecer elementos escritos no procedimento.

Trata-se de uma decorrência de uma preocupação, surgida no seio da Igreja, com a segurança e a documentação de atos até então não suscitados, que pode ser entendida tendo em vista o escopo transcendental do processo na ótica do Direito Canônico.

Verba volant, scripta manent. Sob esta afirmação, plenamente coerente com os anseios por segurança do jurista canônico, os tribunais eclesiásticos assistiram a um progressivo aumento de formalidades no processo civil e, consequentemente, a uma progressiva substituição da oralidade pela escritura. ${ }^{63}$

Afirma ADRIANA CAMPITELLI que Graciano já anotava que Incmaro (806-882), arcebispo de Reims, estabelecera que legum ecclesiasticarum authoritas thalis est ut in causis gestorum semper scriptura requiratur ${ }^{64}$.

A mesma atenção para a documentação dos atos judiciais também pode ser encontrada em Ivo de Chartres, que, ao escrever suas compilações nos anos de 1091 a 1116, anotava que a sentença, após ser prolatada pelo juiz diante das partes, deveria ser reduzida a termo ${ }^{65}$.

Na mesma linha, pode-se afirmar que o processo delineado no Decreto de Graciano já era permeado pelo princípio da escritura, tanto que, no âmbito da

Synthese der gegeben Elemente. NÖRR, Knut Wolfgang. Rechtsgeschichtliche Apostillen zur Clementine Saepe. In: RHEE, C. H. van (Org.). The Law's Delay: Essays on Undue Delay in Civil Litigation. Intersentia, 2004. p. 204. Em tradução livre: Poder-se-ia, inclusive, dizer que a tipificação (no sentido de uma categorização processual paralela à do rito ordinário) fora a verdadeira inovação introduzida no mundo pela Saepe. Isso porque os elementos desta nova tipificação já existiam, tais como, por exemplo, os conceitos que serviram de impulso para o procedimento sumário, bem como as ações e os estágios processuais que diferenciavam este procedimento daquele de caráter ordinário. A inovação, portanto, consistira na seleção e na síntese de elementos já disponíveis naquela realidade jurídica.

62 BIONDI, Biondo. Il diritto romano cristiano. v. 3. Milano: Giuffrè, 1954. p. 376.

63 CAMPITELLI, Adriana. Processo Civile (dir. interm.). Enciclopedia del Diritto, XXXVI. Milano: Giuffrè, 1987. p. 94.

64 CAMPITELLI, Adriana. Processo Civile, p. 95.

65 CRUZ E TUCCI, José Rogério; AZEVEDO, Luiz Carlos. Lições de Direito Processual Civil Canônico. São Paulo: Revista dos Tribunais, 2001. p. 36-37. 
instrução probatória, era corrente a regra segundo a qual o juiz deveria decidir secundum acta et probata ${ }^{66}$, ou seja, negava-se validade à prova não documentada nos autos.

Portanto, pode-se afirmar que Inocêncio III, por meio do cânone quonian contra, prestigiado no IV Concílio de Latrão (1215-1216), não inovou substancialmente o processo até então praticado ao estabelecer a obrigatoriedade de documentação escrita de todos os atos judiciais. Em verdade, apenas tornou expressa uma regra já observada e difundida nos tribunais eclesiásticos. O desenvolvimento técnico do processo não se dá por saltos, e neste ponto particular, a regra não poderia ser diversa.

Assim, o verdadeiro papel desempenhado pela quonian contra foi, segundo CAPPELLETTI, o de eliminar todos os resquícios de oralidade e imediação advindos do processo justinianeu e pós-justinianeu, propiciando a segmentação do procedimento em inúmeras etapas e afastando qualquer possibilidade de contato direto entre as partes ${ }^{67}$.

Deste modo, como afirma CAPPELlETTI, o poder do juiz de interrogar as partes, salvo em determinados procedimentos, praticamente desapareceu. ${ }^{68}$ Isto porque, partindo-se do pressuposto de que as interrogationes deveriam ser reduzidas a escrito pelo notário, passou-se a permitir a apresentação de positiones escritas.

Cumpre notar que, em seu Speculum Iudiciale, GUILHERME DURANTE já se referia, no século XIII, às interrogationes como um instituto do passado, que não mais correspondia à prática dos tribunais de sua época ${ }^{69}$.

No entanto, esta prevalência de atos escritos no processo foi atenuada por duas bulas de Clemente V: Saepe Contingit ${ }^{70}$, de 1306 - também chamada de

66 ADRIANA CAMPITELLI, Processo Civile, p. 95.

${ }^{67}$ CAPPELLETTI, Mauro. La testimonianza della parte nel sistema dell'oralità, Parte Seconda, p. 562.

68 CAPPELLETTI, Mauro. La testimonianza della parte nel sistema dell'oralità, Parte Seconda, p. 563.

69 CAPPELLETTI, Mauro. La testimonianza della parte nel sistema dell'oralità, Parte Seconda, p. 565. Vale lembrar a observação de GIAN ANTONIO MICHELI, no sentido de que, a rigor, as positiones são fruto da concepção germânica das deduções das partes, voltadas não já à instrução da causa, mas sim à decisão da lide. MICHELI, Gian Antonio. L'onere della prova. Padova: Cedam, 1966. p. 37, nota 103.

${ }^{70}$ Saepe contingit, quod causas commitimus, et in earum aliquibus simpliciter et de plano, ac sine strepitu et figura iudicii procedi mandamus; de quorum significatione verborum a multibus contenditur et qualiter procedi debeat dubiatur. Nos autem, dubitationem huiusmodi, (quantum nobis est possibile), decidere cupientes, hac in perpetuam valitura constitutione sancimus, ut iudex, cui taliter causam commitimus, necessario libellum non exigat, litis contestationem non postulet, tempore etiam feriarum, ob valeat, amputed dilationem materiam, litem, quantum poterit, faciat breviorem, exceptiones apellationes dilatorias et frustratorias repellendo, partium, advocatorum et procuratorum contentiones et iurgia, testiumque superfluam multitudinem refrenando. Non sic tam iudex litem abbreviet, quin probationes necessariae et defensiones legitimae admittantur. Grifos ausentes no original. 
Clementina Saepe - e Dispendiosam, de 1311, decorrente do Concílio de Viena ${ }^{71}$. Como já foi ressaltado acima, tais bulas não veicularam ideias propriamente originais; importaram, contudo, na reafirmação e difusão de técnicas já conhecidas. ${ }^{72}$

O objetivo perseguido por meio dessas bulas era a simplificação procedimental, diante da constatação de que os tribunais eclesiásticos mostravam-se incapazes de atingir a pacificação do povo de Deus mediante um processo marcado pela lentidão e pelo excesso de formalismos.

A decretal Clementina Saepe apresentou uma tendência para a simplificação de diversos aspectos do processo do Ordo Solemnis Iudiciourum: suprimiu a necessidade do libellus suplex, atenuou a solenidade da litiscontestatio, aboliu a necessidade de uma série de citações e juramentos e encurtou diversos prazos, entre outras medidas $^{73}$.

O âmbito de aplicação do processo sumário foi se ampliando como o tempo para causas não previstas na Clementina Saepe ${ }^{74}$, de modo que, segundo LEFEBVRE, às vésperas da promulgação do Código de 1917, este era o processo comum do foro canônico. ${ }^{75}$

Contudo, a Clementina Saepe não reduziu a amplitude da cognição do juiz ${ }^{76}$. A celeridade, nas palavras de PAOLO MONETA, não pode obstar a colheita de elementos de convicção para a formação da certeza moral e a obtenção da decisão mais próxima da verdade - valor este que deve prevalecer $^{77}$.

No mesmo sentido, CRUZ E TUCCI e AZEVEDO observam que:o termo sumário, neste contexto, designava tão somente uma forma procedimental

\footnotetext{
71 Dispendiosam prorogationem litium (quam interdum ex subtili ordinis judiciarii observatione causarum docet experientia provenire) restringere in subscripitis casibus cupientes, satatuimus: ut in causis super electionibus, postulationibus, vel provisionibus, aut super dignitatibus, personatibus, officiis, canonicatibus, vel praebendis, seu quibusvis beneficiis ecclesiasticis, aut super decimis, nec non super matrimoniis et usuris, et eas quoquomodo tangentibus ventilandis, procedi valeat de caetero simpliciter et de plano ac sine sprepitu judicii et figura. Grifos ausentes no original.

72 NÖRR, Knut Wolfgang. Rechtsgeschichtliche Apostillen zur Clementine Saepe, p. 204.

73 MADERO, Luis. Comentario Exegético al Código de Derecho Canónico. 3. ed. v. IV/2. Pamplona: Universidade Navarra, 2002. p. 1758.

${ }^{74}$ P. RIDOLPHINI, De ordine procedendi in iudiciis in Romana Curia Praxis recentior, $5^{\mathrm{a}}$ ed., Venetiis, 1703, p. 7-8, apud MADERO, Luis. Comentario Exegético al Código de Derecho Canónico, p. 1758.

75 Procedure, Dictionnaire de Droit Canonique, VII, col. 295, apud LUIS MADERO, Comentario Exegético al Código de Derecho Canónico, p. 1758.

76 CAPPELLETTI, Mauro. La testimonianza della parte nel sistema dell'oralità, Parte Seconda, p. 550552.

77 MONETA, Paolo. Processo giudiziario canonico. Enciclopedia del diritto, Giuffrè, v. XXXVI, 1987, p. 903.
} 
acelerada, que caracteriza, na atualidade, os denominados juízos plenários rápidos. Em tal sede não havia qualquer limitação quanto à cognição, mas, sim, um encurtamento dos prazos procedimentais e dispensa de certas formalidades inerentes ao rito ordinário. ${ }^{78}$

Demais disto, deve-se advertir que não se tratava de prestigiar um processo informado pelo princípio da oralidade e seus corolários lógicos, tal como concebidos hoje. Cientificamente o princípio da oralidade é uma noção moderna, cujas origens remontam ao século XIX. O que se buscava era apenas a eliminação de formalismos vetustos e antiquados, incongruentes com a realidade da época.

As causas das dilações indevidas no processo da época, tal como hoje, certamente não poderiam ser atribuídas a um único fator, mas a um conjunto de fatores, entre os quais a segmentação do processo em diversas fases e a ampla recorribilidade das decisões interlocutórias.

Não só advogados e partes, como também as autoridades judicantes da Igreja tinham interesse na simplificação do procedimento. HeLMHOLZ, num estudo acerca das causas das dilações indevidas nos tribunais eclesiásticos ingleses entre 1350 e 1600, afirma ser falso supor que advogados e bispos viam nas dilações indevidas do processo uma forma de aumentar seus ganhos patrimoniais. ${ }^{79}$

Anota o citado autor que era comum naquele período advogados preocupados com a duração excessiva dos processos pleitearem a aplicação das bulas Saepe Contingit e Dispendiosam, visando à simplificação do procedimento. ${ }^{80}$

Por exemplo, num litígio matrimonial de 1338 (Alice Wetherby v. John Page), o advogado de uma das partes expressamente pleiteou que o processo se desenvolvesse de plano ac sine strepitu et figura iudicii, o que foi concedido pelo bispo de York. Num outro caso de 1485 (Bekyn v. Morys) o advogado do réu pleiteou ao bispo de Bath and Wells que o processo tramitasse summarie et de plano, o que não foi deferido pois as partes, de comum acordo, decidiram submeter a processo à arbitragem. ${ }^{81}$

\footnotetext{
78 CRUZ E TUCCI, José Rogério; AZEVEDO, Luiz Carlos. Lições de Direito Processual Civil Canônico, p. 60 .

79 HELMHOLZ, R. H. Undue delay in English Ecclesiastical Courts (circa 1350-1600). In: RHEE, C. H. van (Org.). The Law's Delay: Essays on Undue Delay in Civil Litigation. Intersentia, 2004. p. 134.

80 HELMHOLZ, R. H. Undue delay in English Ecclesiastical Courts, p. 135.

81 HELMHOLZ, R. H. Undue delay in English Ecclesiastical Courts (circa 1350-1600), p. 135.
} 
Demais disso, segundo HELMHOLZ, medidas para acelerar o procedimento conferindo-lhe maior concentração, por iniciativa das partes, eram comuns no período por ele analisado. Ainda que a expressão processo sumário não fosse mencionada na generalidade das fontes, a condensação de diversas etapas do procedimento numa mesma audiência, em razão do pedido de uma ou de ambas as partes, era uma prática normal para conferir ao procedimento maior celeridade. ${ }^{82}$

Pode-se assim observar que a preocupação com a rápida solução dos litígios no povo de Deus era uma constante no processo civil canônico. Contudo, ainda que seja inegável esta tendência de simplificação procedimental numa perspectiva histórica, em nenhum momento se abriu mão da necessidade de documentação dos atos.

Neste sentido, EICHMANN é enfático ao afirmar que “el procedimiento canónico está dominado por el principio del sistema escrito. Tiene la finalidad de fijar los procesos judicialmente importantes, contra futuras controversias. Todas las declaraciones importantes jurídicamente, actos y processos, deben hacerse constar por el actuario en el protocolo judicial; pues solamente esto puede servir de base a la resolución: quod non est in actis non est in mundo". ${ }^{83}$

\subsection{ORALIDADE NO DIREITO ROMANO VULGAR E NOS DIREITOS GERMÂNICOS NA PENÍNSULA IBÉRICA}

Com Otaviano Augusto (63 a.C. - 14 d.C.), iniciou-se um longo processo de romanização dos povos germânicos que habitavam a Hispania. MARCELLO CAETANO afirma que os principais fatores que desencadearam essa precoce assimilação da cultura romana - e sobretudo do direito romano - pelos povos que habitavam a Península Ibérica foram a ação de legiões romanas, a existência das estradas romanas, o estabelecimentos de colonos romanos na península e a difusão do cristianismo. ${ }^{84}$

Mas tal assimilação não poderia ser completa. A mesma lógica que determinaria a gênese do latim vulgar falado nas províncias também explicaria a formação do direito romano vulgar: entre vencedores e vencidos as influências são recíprocas.

82 HELMHOLZ, R. H. Undue delay in English Ecclesiastical, p. 135.

83 EICHMANN, Eduard. Manual de Derecho Eclesiástico a tenor del Codex Juris Canonici. Trad. da 3. ed. alemã de T. Gómez Piñan. t. II. Barcelona: Libreria Bosch, 1931. p. 347.

84 CAETANO, Marcello. História do Direito Português. 4. ed. Lisboa: Verbo, 2000. p. 63-64. 
Assim, o direito romano vulgar passou a ser forjado a partir dos direitos germânicos dos povos conquistados e do direito romano.

Pouco se sabe sobre o direito romano vulgar da Hispania, de modo que pouco poderia ser dito sobre as características do método de resolução de conflitos utilizado pelos colonos romanos no extremo ocidente do império. Todavia, levando-se em conta apenas o elemento romano, seria possível especular que algum elemento escrito poderia fazer-se presente, considerando-se o estágio de evolução do processo civil romano por volta do século II d.C.

Todavia, a administração da justiça era incumbência de juízes eleitos na própria localidade, os quais, em sua maioria, eram analfabetos e julgavam de acordo com o costume. Além disso, não havia em Portugal até o século XIII o ensino formal do Direito. ${ }^{85}$ Neste contexto, a resolução de litígios civis não poderia deixar de estar marcada por um certo primitivismo.

\subsection{ORALIDADE E ESCRITURA NO PROCESSO DO PERÍODO DA CONSOLIDAÇÃO DA MONARQUIA PORTUGUESA}

Foi somente com a consolidação da monarquia portuguesa, sobretudo durante os reinados de D. Afonso III, D. Dinis, e D. Afonso IV, que houve um aprimoramento da justiça pública. ${ }^{86}$ Não obstante, até o início do século XIV, a jurisdição

85 CAETANO, Marcello. História do Direito Português, p. 231.

86 JOSÉ PEDRO RIBEIRO aponta que o preâmbulo das Cortes de Coimbra de 1211 (ano da era de César de 1249), faz menção à nomeação de juízes por D. Afonso II (1211-1223) no primeiro ano de seu reinado, o que poderia evidenciar que a prática de nomeação de magistrados diretamente pelo rei poderia ter se iniciado nesta época. Todavia, as fontes indicadas pelo autor - as atas das Cortes de Coimbra do Real Arquivo foram vertidas do latim para o português, o que poderia ter propiciado algum erro de tradução. (RIBEIRO, José Pedro. Sobre a economia dos Juizes de primeira Instancia no nosso Reino desde o Governo dos Reis de Leão. Dissertação XXI. In: Dissertações Chronologicas e criticas sobre a historia e jurisprudência ecllesiastica e civil de Portugal, t. V. Lisboa: Academia Real das Sciencias, 1836. p. 136-137). É possível que o documento analisado por JOSÉ PEDRO RIBEIRO em verdade fizesse referência ao juízes que, embora eleitos pelos concelhos municipais, deveriam prestar juramento na Casa de El-Rei, pagando para tanto emolumentos à Coroa. Em época posterior, com Regimento dos Corregedores de 1340, esta competência teria sido delegada aos corregedores, como forma de aliviar o trabalho da Chancelaria régia (CAETANO, Marcello. História do Direito Português, p. 374-375). Deveras, JOSÉ ANASTASIO DE FIGUEIREDO afirma que os juízes de fora remontam, no máximo, ao reinado de D. Afonso IV (13251357), citando, para fundamentar sua assertiva, referências de indicação de magistrados pelo rei nas Cortes de Elvas de 1352 (ano da era de César de 1390), sendo que a mesma data é indicada por DUARTE NUNES DE LEÃO (FIGUEIREDO, José Anastácio. Sobre a origem dos nossos Juízes de Fora. In: Memorias da Litteratura Portugueza. t. I. Lisboa: Academia Real das Sciencias de Lisboa, 1792. p. 32). A indicação de juízes diretamente pelo rei também encontra subsídio durante o reinado de D. João I (1385-1433), sendo que 
em primeira instância era exercida pelos juízes ordinários, mantido o sistema eletivo, exigindo-se, contudo, a chancela régia para o exercício da judicatura. A partir do reinado de D. Afonso IV há registros de nomeação de juízes diretamente pelo rei (juízes de el-rei ou juízes de fora).

Uma lei - presumivelmente de D. Dinis -, corroborando um antigo costume, permitia que os juízes ordinários designassem juízes delegados para a instrução do processo. ${ }^{87}$ Verifica-se, portanto, que a delegação de atividades instrutórias e a ausência de imediação na produção da prova possuem raízes assaz antigas no direito lusitano.

Uma lei de D. Fernando datada de 1379 buscava prestigiar a prova documental em detrimento da prova testemunhal. Em razão do protesto dos povos, tal lei veio a ser revogada por ocasião das Cortes Gerais de 1385, mas foi restabelecida por uma lei de D. João I em 1406, com alguns aditamentos, vindo a ser posteriormente recolhida nas Ordenações Afonsinas (Ord. Afon. 3.64). ${ }^{88}$

Trata-se, como bem observa PASCOAL JOSÉ DE MELLO FREIRE, da tradicional regra segundo a qual determinados contratos só podem ser provados por escritura pública, ${ }^{89}$ regra esta reproduzida em todas Ordenações (Ord. Fil. 3.59 e Ord. Man.3.45), e que inclusive chegou aos dias atuais.

\subsection{ORALIDADE E ESCRITURA NO PROCESSO CIVIL DAS ORDENAÇÕES DO REINO}

\subsubsection{TENTATIVA DE CONCILIAÇÃO E COMPARECIMENTO PESSOAL DAS PARTES}

A tentativa de conciliação era um dever do juiz, devendo ter lugar no começo da demanda, logo no início da primeira audiência. No entanto, é importante observar que não se tratava de uma etapa obrigatória do procedimento, mas sim

a lei por este instituída se encontra na Ord. Afon.1.25, tendo sido tal prática referendada por D. Afonso V (1438-1481).

87 CAETANO, Marcello. História do Direito Português, p. 375.

88 CAETANO, Marcello. História do Direito Português, p. 381-282.

89 FREIRE, Pascoal José de Mello. Instituições de Direito Civil Português. Tradução de Miguel Pinto Meneses. Boletim do Ministério da Justiça, Lisboa, n. 161-162, 1966. p. 64. 
facultativa, a depender das circunstâncias de cada caso: $E$ isto, que dissemos de reduzirem as partes à concórdia, não é de necessidade, mas somente de honestidade nos casos em que bem puderem fazer (Ord. Fil. 3.20.1; Ord. Man. 3.15.1; e Ord. Afon. 3.25.5).

Aliás, a facultatividade da tentativa de conciliação é coerente com a não exigência de comparecimento pessoal do réu, que poderia, em regra, se fazer representar por procurador (Ord. Fil. 3.20.3; Ord. Man. 3.7; e Ord. Afon. 3.8). Nada obstaria, é claro, que das próprias procurações constasse o poder expresso para o procurador transigir, possibilitando, em tese, a tentativa de conciliação. As Ordenações, ao tratarem do mecanismo de controle da representatividade do procurador, dispunham que era dever do juiz verificar se as procurações eram bastantes para o caso em que são oferecidas (Ord. Fil. 3.20.10 Ord. Man. 3.15.10; e Ord. Afon. 3.15.11), silenciado acerca dos poderes para transigir. Assim, não sendo a presença do réu obrigatória, e sendo possível a constituição de procurador sem poderes para transigir, a tentativa de conciliação somente pode ser considerada como uma etapa facultativa do procedimento.

Todavia, sendo citado expressamente para se apresentar em pessoa, para responder a determinadas perguntas, o comparecimento pessoal passaria a ser obrigatório (Ord. Fil. 3.7; Ord. Man. 3.7. e Ord. Afon. 3.8). Note-se, não obstante, que o comparecimento pessoal do réu se fazia em prol da instrução, e não em benefício da tentativa de conciliação, que, conforme já afirmado, era considerada uma etapa não obrigatória do procedimento, embora recomendada com veemência pelo legislador.

A conciliação somente se tornaria obrigatória no Brasil Independente, por força do artigo 161 da Constituição do Império, que igualmente inovou ao prever a criação da justiça de paz. A prévia tentativa de conciliação perante o juiz de paz era um pressuposto de ordem constitucional para a propositura de qualquer demanda. ${ }^{90}$

Já a Disposição Provisória acerca da Administração da Justiça Civil de 1832 disciplinou a conciliação de forma um pouco diversa. Em seu artigo $6^{\circ}$, foi estabelecido que nas causas, em que as partes não podem transigir, como Procuradores Publicos, Tutores, Testamenteiros; nas causas arbitraes, inventarios, e execuções; nas de simples officio do Juiz; e nas de responsabilidade; não haverá conciliação.

${ }^{90}$ Art. 161. Sem se fazer constar, que se tem intentado o meio da reconciliação, não se começará Processo algum.

Art. 162. Para este fim haverá juizes de Paz, os quaes serão electivos pelo mesmo tempo, e maneira, por que se elegem os Vereadores das Camaras. Suas attribuições, e Districtos serão regulados por Lei. 
FRANCISCO DE PAULA BAPTISTA afirmava que o dispositivo era inútil, porquanto cingia-se a reproduzir o texto constitucional. ${ }^{91}$ Todavia, é preciso reconhecer que o texto do artigo $6^{\circ}$ da Disposição Provisória explicitou as exceções à obrigatoriedade da conciliação que implicitamente estavam previstas na Constituição do Império, facilitando a aplicação da norma constitucional.

Tanto é verdade que o referido dispositivo era pertinente, que tal técnica foi reproduzida pelo Regulamento 737 de 1850, o qual repetiu a dicção da Constituição no sentido de ser obrigatória a conciliação pré-processual em seu artigo 23, arrolando expressamente os casos que implicitamente não poderiam ter sido abrangidos pela norma constitucional nos parágrafos do referido artigo.

A razão de ser da conciliação pré-processual obrigatória é bem anotada por ANTONIO RIBAS. Afirma o conselheiro que na verdade, este preceito não é destinado a salvaguardar direitos dos litigantes; é sim inspirado por uma grande ideia de interesse público - a de evitar litígios e manter a harmonia entre os cidadãos. ${ }^{92} \mathrm{~A}$ finalidade da tentativa de conciliação obrigatória prevista na Constituição de 1824 afastase, deste modo, das razões pelas quais os meios autocompositivos de resolução de conflitos são valorizados hodiernamente. Não há uma preocupação em dar um tratamento mais adequado para o conflito entre as partes, bem como não há o reconhecimento da inadequação, em muitos casos, da resolução adjudicada, especialmente quando as partes envolvidas mantêm relações continuativas (e.g. relações de direito de família, societárias, de vizinhança, etc.). O incentivo à conciliação, nesse momento histórico, é visto apenas como um modo de reduzir custos na administração da justiça.

A obrigatoriedade da conciliação somente foi rompida em época republicana, com o Decreto 359 de 26 de abril de 1890, que aboliu a conciliação como formalidade preliminar ou essencial para serem intentadas ou prosseguirem as ações cíveis ou comerciais. ${ }^{93}$

91 BAPTISTA, Francisco de Paula. Compendio de Theoria e Pratica do Processo Civil comparado com o Commercial e de hermenêutica jurídica. 8. ed. São Paulo: Saraiva, 1909. p. 3, nota 2.

92 RIBAS, Antonio. Consolidação das Leis do Processo Civil commentada. v. 1, Rio de Janeiro: Dias da Silva Júnior, 1879. p. 149-150, comentário 109.

${ }_{93}$ COSTA, Moacyr Lobo da. Breve notícia histórica do Direito Processual Civil Brasileiro e de sua literatura. São Paulo: Revista dos Tribunais, 1970. p. 57. 


\subsubsection{AUSÊNCIA DE COOPERAÇÃO DO JUIZ COM AS PARTES}

Não há sob o regime das Ordenações o dever de colaboração do juiz com as partes. No que se refere à emenda ou à correção das manifestações das partes, o juiz não precisava apontar em que consistia a sua não concordância quanto à ausência de regularidade da manifestação da parte, bastando, ao rejeitá-la, assinar prazo para a emenda, por até três vezes. (Ord. Man. 3.15.17).

Nas Ordenações, o modelo de conduta para o juiz em relação às partes era essencialmente não cooperativo. E quando mandarem emendar alguns artigos, não declararão as cousas, em que se hão de emendar, porque não deve ensinar as partes, nem a seus procuradores, como hão de formar seus artigos. (Ord. Fil. 1.6.22.)

Todavia, é possível identificar uma ideia embrionária de cooperação do juiz com as partes na técnica de julgamento pela verdade sabida, porquanto permitia ao julgador relevar eventuais deficiências das manifestações das partes, determinando a sua emenda.

\subsubsection{DO JULGAMENTO PELA VERDADE SABIDA SEM EMBARGO DO ERRO DO PROCESSO}

A técnica do julgamento segundo a verdade, que pelos processos for provada e sabida, sem embargo do erro do processo, permitia ao juiz desconsiderar vícios formais, evitando a anulação do processo, por meio de um juízo de equidade $-e o$ Julgador julgou o que lhe pareceo justiça (Ord. Fil. 3.63; Ord. Man. 3.49; Ord. Afon. 3.68).

Sendo alegado vício de forma pelas partes em primeira instância, antes da prolação da sentença definitiva, cabia ao juiz sanar tais irregularidades, não havendo assim prejuízo aos atos já praticados. O próprio texto legal exemplifica com o caso da procuração não suficiente, que não implicaria invalidade dos atos praticados, caso o defeito fosse oportunamente sanado pela parte. (Ord. Fil. 3.63.1; Ord. Man. 3.49.1; Ord. Afon. 3.68.4). 
Demais disso, a possibilidade de o juiz determinar o suprimento de irregularidades com o escopo de evitar a anulação do processo não se limitava à primeira instância. Havia autorização no texto das Ordenações Filipinas e Manuelinas para que, mesmo após a sentença de primeira instância, o juiz da apelação ou do agravo poderia mandar suprir os erros alegados pelas partes, evitando-se a anulação do processo. Neste caso, o juiz de primeiro grau deveria ser condenado pelas custas de retardamento (Ord. Fil. 3.63.2; e Ord. Man. 3.49.2). Todavia, para que o juiz sofresse tal condenação era imprescindível que houvesse expressa alegação da parte interessada sobre erro de forma e a subsequente inércia do julgador em não mandar suprir a irregularidade. Não bastava a mera ocorrência do vício de forma, pois não era função do juiz, sob a ótica das Ordenações, ensinar as partes, nem a seus procuradores, como hão de formar seus artigos (Ord. Fil. 1.6.22.).

\subsubsection{INTRODUÇÃO DA DEMANDA DE FORMA ORAL}

As Ordenações previam a possibilidade de introdução da demanda de forma oral, sem a obrigatoriedade de o autor formar libelo por escrito, até um certo valor de alçada $^{94}$, ou, independentemente do valor, versando a demanda sobre determinadas matérias (Ord. Fil. 3.30.1; Ord. Man. 3.20, Ord. Afon. 3.24). De modo idêntico, não se exigia a forma escrita para a resposta do réu, que era ouvido summariamente per palavra (Ord. Fil. 3.30.1).

Neste procedimento sumarizado, a execução da sentença também seguia um rito simplificado, dispensando-se que a sentença fosse retirada do processo pelo escrivão, ou seja, não se exigia que o escrivão redigisse outra via integral da sentença, bastando para tal fim um alvará assinado pelo juiz contendo apenas o dispositivo da decisão (Ord. Fil. 3.30.1; Ord. Man. 3.19.1). A influência canônica deste procedimento sumarizado fica evidente ao se afirmar que procederá o Julgador summariamente sem strepido, nem figura de juízo (Ord. Fil. 3.30.3; Ord. Man. 3.19.3; e Ord. Afon. 3.24),

${ }^{94}$ Sob o regime das Ordenações Filipinas, este valor era de mil réis. Para se ter uma noção do que significava esta quantia, basta pensar que 20 réis diários era o valor máximo que o carcereiro poderia gastar com a alimentação de um escravo preso (Ord. Fil. 1.33.11). Logo, o valor de alçada de mil réis equivalia ao valor necessário para alimentar um escravo por 50 dias. 
reproduzindo literalmente o primeiro parágrafo da famosa Bula de Clemenente V de 1306 (Saepe contingit, quod causas commitimus, et in earum aliquibus simpliciter et de plano, ac sine strepitu et figura iudicii procedi mandamus...).

Contudo, isso não significava ausência de documentação do pedido em registro escrito, vez que em tais casos o tabelião ou escrivão deveria reduzir a escrito o pedido do autor. Não se pode confundir a dicotomia oralidade e escritura na conformação do procedimento (sujeita, numa perspectiva histórica, a flutuações para um ou outro lado) com o movimento sempre progressivo da documentação dos atos processuais, que avançava no lento ritmo em que recuava o analfabetismo generalizado e se aprimoravam os meios técnicos de escrita.

Aliás, a obrigatoriedade de manutenção de registros escritos das alegações das partes, bem como das decisões do juiz, foi algo que se manifestou em toda Europa desta época. Nesta linha, ROBERT WYNESS MILLAR afirma que nos principados germânicos podia-se observar, num primeiro momento, a possibilidade de introdução da demanda de forma oral perante um escrivão, que deveria reduzir a escrito o pedido - in die Feder zu dictiren. Num segundo momento, facultava-se às partes trazer desde logo as alegações em forma de petição escrita (recessus scriptus loco oralis). Finalmente, este processo culminou na obrigatoriedade da introdução escrita da demanda, como regra geral. $^{95}$

É interessante notar que nas Cortes de Évora (1481-1482), o arrazoamento da demanda de forma escrita já era visto como um mecanismo para coibir abusos em juízo por parte dos procuradores. D. João II (1455-1495), diante de diversas reclamações versando sobre a abundância e os abusos de procuradores em juízo, determinou que os procuradores deveriam obrigatoriamente arrazoar por escrito, e não oralmente, bem como deveriam as partes responder às perguntas que lhe forem formuladas sem a intervenção de seus procuradores. ${ }^{96}$

95 MILLAR, Robert Wyness. Formative Principles of Civil Procedure. In: ENGELMANN, Arthur (Org.). A History of Continental Civil Procedure. New York: Rothman Reprints; Augustus Kelley, 1969. p. 50-51.

96 CAETANO, Marcello. História do Direito Português, p. 583, nota 1. 


\subsubsection{MEDIAÇÃO NA COLHEITA DA PROVA TESTEMUNHAL E OITIVA DAS PARTES SEM A PRESENÇA DO JULGADOR}

A mediação na produção da prova testemunhal, ou seja, a oitiva da testemunha por interposta pessoa, segundo afirma ROBERT WYNESS MILLAR, foi a regra amplamente dominante na Europa Continental por muitos séculos. ${ }^{97}$ Neste sentido, Portugal não foi uma exceção.

Admitia-se, no regime das Ordenações, a oitiva das partes sem a presença física do juiz. Neste caso, o depoimento era feito junto ao escrivão ou ao tabelião. Estabelecia-se que a parte que deixasse de responder a uma pergunta formulada pelo juiz, salvo em se tratando de artigos criminosos (Ord. Fil. 3.53.11; Ord. Man. 3.40.12; e Ord. Afon. 3.58.15 - que exprimem a essência do princípio nemo tenetur se detegere), estaria sujeita à pena de confesso, postoque não seja presente o Julgador, se elle mandar dizer a parte por Scrivão, ou Tabelião do feito (Ord. Fil. 3.53.13; e Ord. Man. 3.40.13).

Além disso, a própria disciplina da função de enqueredor no Livro I das três Ordenações também demonstrava uma separação entre a atividade de colheita e registro da prova testemunhal, e a atividade judicante. A legislação portuguesa mostra-se muito rica nesta matéria, estabelecendo o dever de o enqueredor desempenhar o seu ofício com diligência e boa discrição, devendo inclusive fazer constarem do registro escrito do depoimento as alterações na fala e nas reações corpóreas da testemunha. Pela expressividade, vale transcrever o seguinte dispositivo:

E attentem bem com que aspecto e constancia fallam, e se variam, ou vacillam, ou mudam a cor, ou se torvam na falla, em maneira, que lhes pareça, que são falsas, ou suspeitas. E quando assi o virem, ou sentirem, devem-no notificar ao Julgador do Feito, se for no lugar onde se tiram a inquirição: e se for absente ,mandarão aos Scrivães, ou Tabelliães que screvam as ditas torvações e desvarios das testemunhas, a que acontecer, para o Juiz, que houver de julgar o feito, prover nisso, como lhe parecer justiça. (Ord. Fil. 1.86.1. A regra também consta em Ord. Man.1.65.1; e Ord. Afon. 1.41, com pequenas variações de redação).

97 MILLAR, Robert Wyness. Formative Principles of Civil Procedure, p. 64-65. 
O enqueredor português encontrava paralelo com o receptor da legislação espanhola, função já amplamente disciplinada em leis que datam do início do século XVI, recolhidas na Novíssima Recopilación (Liv. 11, Tít. 11). De igual modo, ROBERT WYNESS MILLAR afirma que no direito comum dos principados germânicos era difundida a prática de delegação da instrução do processo a um dos membros do colegiado ou a um estranho ao corpo judicante, o Komissar. ${ }^{98}$

Na legislação brasileira, segundo CÂNDIDO MENDES, ${ }^{99}$ o ofício de enquererdor somente foi abolido na Disposição Provisória acerca da Administração da Justiça Civil de 1832, que determinou a aplicação dos artigos 262, 263 e 264 do Código de Processo Criminal do Império ${ }^{100}$, de modo que as testemunhas passaram a ser inquiridas publicamente pelas próprias partes ou seus procuradores.

Todavia, o disposto na Ordenação Filipina 1.86.1 foi reproduzido no artigo 421, §7º da Consolidação Ribas, alterando-se, contudo, o destinatário da norma. O que era uma obrigação do enqueredor passou a ser uma obrigação do juiz.

A necessidade de haver uma completa e pormenorizada descrição do relato das testemunhas foi afastada em relação ao procedimento sumário por força do artigo 27 da Lei 2.033, de 20 de setembro de 1871, e do artigo 243 do Regulamento 737.

No entanto, a falta de contato direto entre o juiz e as testemunhas persistiu, pois se admitia a figura do Juiz Municipal, com funções típicas de um juiz de instrução, responsável pela condução do processo até o final da fase de instrução.

O contato imediato do julgador com as testemunhas era a exceção, pois apenas ocorria nos casos em que a instrução fosse presidida diretamente pelo próprio Juiz de Direito, ou nas hipóteses em que este entendesse necessário reperguntar testemunhas já inquiridas pelo Juiz Municipal (art. $9^{\circ}$ da Disposição Provisória de 1832).

98 MILLAR, Robert Wyness. Formative Principles of Civil Procedure, p. 65.

99 ALMEIDA, Cândido Mendes de. Código Philippino ou Ordenações e Leis do Reino de Portugal recopiladas por mandado D'el-Rey D. Phillippe I. 14. ed. Rio de Janeiro: Typographia do Instituto Philomáthico, 1870. Livro1, p. 203, nota 1.

${ }^{100}$ Os artigos citados faziam parte da disciplina da oitiva de testemunhas perante o conselho de sentença no procedimento do júri:

Art. 262. As testemunhas do accusador serão introduzidas na sala da sessão, e jurarão sobre os artigos, sendo primeiro inquiridas pelo acccusador, ou seu Advogado, ou Procurador, e depois pelo réo, seu Advogado, ou Procurador.

Art. 263. Findo este acto, o Advogado do réo desenvolverá sua defesa, apresentando a Lei, e referindo os factos, que sustentam a innocencia do réo, deduzidos em artigos succintos, e claros.

Art. 264. As testemunhas do réo serão introduzidas, e jurarão sobre os artigos, sendo inquiridas primeiro pelo Advogado do réo, e depois pelo do accusador, ou autor. 


\subsubsection{REINQUIRIÇÃO DE TESTEMUNHAS NO TRIBUNAL}

As Ordenações Manuelinas e Filipinas permitiam a reinquirição de testemunhas no tribunal, desde que houvesse pedido da parte interessada e desde que aos desembargadores parecesse necessária tal providência (Ord. Fil. 3.45.6; Ord. Man. 3.42.5). A parte que pretendesse ouvir novamente as testemunhas perante a Corte ficava obrigada a custear suas despesas de transporte e hospedagem, bem como a ressarcir o que elas deixassem de ganhar no exercício de seus ofícios. Todavia, as testemunhas residentes nas colônias de além-mar só poderiam ser requisitadas por mandado do próprio rei. (Ord. Fil. 3.45.6; Ord. Man. 3.42.5). Nas Ordenações Afonsinas, contudo, não havia dispositivo semelhante.

É interessante notar que na legislação espanhola havia um dispositivo em sentido diametralmente oposto. Uma lei datada de 1476, de D. Fernando II de Aragão (1452-1516) e $\mathrm{D}^{\mathrm{a}}$. Isabel I, de Castela (1451-1504), recolhida na Novíssima Recopilación (Livro 11, Título 10, Lei 6), vedava o recebimento de prova testemunhal em segunda instância quando a testemunha contrariasse o que havia afirmado em primeira instância. O objetivo expresso da lei era coibir que as testemunhas fossem corrompidas ou subornadas, de modo a causar nos feitos muito dano e fadiga. Não obstante, a prova testemunhal era permitida em segunda instância para a prova de exceções não formuladas em primeira instância ou, ainda, rechaçadas pelo primeiro julgador por inobservância das devidas formalidades (Novíssima Recopilación, Livro 11, Título 10, Lei 7).

\subsection{A DISPOSIÇÃO PROVISÓRIA DE 1832 E A ORALIDADE NA VISÃO DE MOACYR LOBO DA COSTA}

Na visão de MOACYR LOBO DA COSTA, a Disposição Provisória acerca da Administração da Justiça Civil, de 29 de novembro de 1832, teria antecipado em quase um século as ideias que iriam revolucionar o processo civil na Europa Continental no início do século XX. Contudo, por força de um conservadorismo dos profissionais do foro e em razão de mudanças no cenário político, o propósito de 
simplificação e concentração do procedimento perseguido por seus elaboradores não pôde ser alcançado. Pela expressividade de suas palavras, vale transcrevê-las:

Antecipando-se a Chiovenda e aos demais pregoeiros da oralidade processual e seus postulados, os autores da reforma de 1832 consagraram, com quase um século de antecedência, os princípios da imediatidade do juiz com as provas, da publicidade dos atos probatórios, especialmente inquirição de testemunhas, da simplificação das cartas de sentença para execução, da irrecorribilidade em separado dos despachos e ordinatórios e interlocutórios, da unirrecorribilidade das sentenças definitivas ou com força de definitivas pela apelação, da eventualidade com a supressão da réplica e tréplica, o que impunha às partes o dever de deduzir no libelo e na contrariedade todas as questões e todos os argumentos em prol do seu direito, em suma, da maior, parte daqueles requisitos que muitos anos mais tarde iriam ser apontados pelos processualistas europeus como condição de aprimoramento do processo civil. ${ }^{101}$

Todavia, a afirmação de MOACYR LOBO DA COSTA acima citada merece algumas ponderações. No que se refere à imediação do juiz em relação às provas, embora tenha ocorrido a abolição da figura do enqueredor (art. 25), a falta de contato direto do juiz com as provas continuou sendo a regra geral, haja vista a delegação de competência aos Juizes Municipaes para conduzir o processo até a sentença final, exclusive (art. $8^{\circ}$ ). A reinquirição de testemunhas pelo próprio Juiz de Direito era uma medida excepcional, e não a regra geral (art. $\left.9^{\circ}\right)$.

No que se refere à publicidade dos atos probatórios (art. 11), é preciso esclarecer que, na tradição continental, esta não é uma ideia própria das reforma processuais do século XX, mas sim um fruto da Revolução Francesa. ${ }^{102}$ No Brasil, a publicidade dos atos processuais, ao menos no processo penal, já era uma garantia constitucional desde a Constituição de 1824 (art. 159), e neste ponto, o Código Criminal do Império limitou-se a repetir o preceito constitucional.

${ }^{101}$ COSTA, Moacyr Lobo da. Breve notícia histórica do Direito Processual Civil Brasileiro e de sua literatura, p. 10.

${ }^{102}$ No âmbito do processo penal é possível identificar com clareza a afirmação do princípio da publicidade já na passagem do século XVIII para o século XIX. No plano político, temos a famosa frase de Mirabeau: Donnez-moi le juge que voudrez, partial, corrumpu, mon ennemi même, si vous voulez: peu m'importe porvu qu'il ne puisse rien faire qu'à la face du public. No âmbito jurídico, a obra de FEUERBACH (Betrachtungen über die Oeffenlichkeit und Mündlichkeit der Gereichtigkeitspflege), de 1821, igualmente representa um rompimento com a tradição de julgamento a portas fechadas do direito comum. 
No âmbito do processo civil, diante da incompatibilidade entre o procedimento para inquirição de testemunhas prevista nas Ordenações Filipinas com a estruturação do Poder Judicial instituído pela Constituição de 1824 (arts. 151 e 152), a solução encontrada pelos autores da Disposição Provisória de 1832 (art. 11) foi apenas determinar a aplicação do procedimento de inquirição de testemunhas do Código de Processo Criminal (arts. 262 a 264) ao processo civil. Assim, a publicidade dos atos de instrução no processo civil brasileiro surgiu ao serem tomadas de empréstimo as regras de oitiva de testemunhas do processo penal, não sendo possível também neste ponto afirmar qualquer ímpeto vanguardista do legislador brasileiro.

Também é preciso fazer algumas considerações entorno da afirmação de MOACYR LOBO DA COSTA no sentido de que o artigo 14 da Disposição Provisória de 1832, ao revogar todas as leis que permitiam às partes réplicas e tréplicas, teria imposto às partes o dever de deduzir no libelo e na contrariedade todas as questões $e$ todos os argumentos em prol do seu direito. Embora tal ideia de fato fizesse parte do discurso em prol da reforma do processo civil na passagem do século XIX para o século XX em diversos países da Europa Continental, tal concepção não era nova em $1832 .{ }^{103}$

Demais disso, a oralidade no processo já era uma ideia arraigada no século XIX, todavia com contornos diversos da oralidade no pensamento de KLEIN, CHIOVEndA, ou mesmo de TISSIER. A Constituição do Império Alemão de 1848 (Paulkirchverfassung) já elevava a oralidade a um status constitucional, ao lado da publicidade. $^{104}$

No que se refere à regra da eventualidade, realmente a Disposição Provisória guardava um aspecto vanguardista, mesmo em relação às codificações europeias de maior relevo do final do século XIX. Basta observar que na sistemática original da ZPO alemã de 1877, as manifestações das partes deveriam ser todas orais, e nas audiências as partes não poderiam fazer referências às suas manifestações escritas como forma de abreviar suas exposições orais.

Em relação ao momento da estabilização dos elementos objetivos da demanda, o formalismo da oralidade desempenhava reflexos nocivos em relação à duração do processo. Não havia preclusão das causae petendi e causae excipiendi omitidas

\footnotetext{
103 Neste sentido, MILLAR, Robert Wyness. Formative Principles of Civil Procedure, p. 26-36.

104 \$178. Das Gerichtsverfahren soll öffentlich und mündlich sein. Ausnahmen von der Öffentlichkeit bestimmt im Interesse der Sittlichkeit das Gesetz.
} 
nas manifestações escritas, podendo as partes apresentá-las em suas manifestações orais. E mesmo que a discussão oral da demanda se desdobrasse por vários dias, as partes poderiam apresentá-las até a última oportunidade, dado o princípio da unidade da audiência. $^{105}$

A despeito destas considerações, é preciso anotar que a abolição da réplica, da tréplica, do agravo de petição e do agravo de instrumento, pela Disposição Provisória de 1832, durou pouco mais de nove anos. Em 1841, com a maioridade antecipada de D. Pedro II e o consequente término do período regencial, revogou-se o artigo 14 da Disposição Provisória, com a repristinação expressa da legislação anterior (art. 120 da Lei 261, de 3 de dezembro de 1841), ou seja, restabelecendo-se em grande parte o vetusto procedimento das Ordenações Filipinas.

\subsection{CÓDIGO DO PROCESSO DO ESTADO DA BAHIA DE 1915 E A INFLUÊNCIA DA ZPO AUSTRÍACA DE 1895 SOBRE O PENSAMENTO DE EDUARDO ESPÍNOLA}

A influência da experiência processual civil austríaca da $Z P O$ de 1895 refletiu de forma significativa no pensamento de EDUARDO ESPÍNOLA, responsável pela elaboração do Código do Processo do Estado da Bahia (Lei 1.121, de 21 de agosto de 1915). No que se refere ao papel do juiz na condução do processo, ESPíNOLA é explícito quanto a sua orientação: O Projecto procura, de acordo com os Códigos húngaro, austríaco, e allemão, elevar a dignidade do juiz, confiando-lhe um papel muito mais importante que o de fiel da balança, a se mover cegamente de conformidade com o peso que cada um dos litigantes ponha sobre a concha. ${ }^{106}$

ESPÍNOLA, invocando aquilo que ele denomina de princípio da verbalidade, busca encurtar a fase de debates escritos na codificação baiana, eliminado a necessidade de réplica e tréplica como regra geral do procedimento. Vale notar que a

\footnotetext{
${ }^{105}$ LEIPOLD, Dieter. Oral and Written Elements within the Introductory Phase of Civil Proceedings. In: CARPI, Federico; ORTELLS, Manuel (Org.). Oralidad y Escritura en un Proceso Civil Eficiente (Oral and Written Proceedings: Efficiency in Civil Procedure). v. I - Ponencias generales e informes nacionales (General reports and national reports). València: International Association of Procedural Law (IAPL), Universitat de València, 2008. p. 74-75.

${ }^{106}$ ESPÍNOLA, Eduardo. Código do Estado da Bahia Annotado. Typ. Bahiana de Cincinnato Melchiades, 1918. p. 412-413, nota 99.
} 
Disposição Provisória de 1832 já havia trilhado este caminho (art. 14), mas a Lei 262, de 3 de dezembro de 1841, havia restabelecido a réplica e a tréplica.

O autor tece ainda considerações críticas, neste ponto, à opção do Código de Processo do Distrito Federal de 1911, sustentando que uma vez estabelecida a concentração da defesa na contestação, a adoção da réplica e da tréplica como regra geral significaria multiplicar atos escriptos absolutamente inúteis. ${ }^{107}$

Outro ponto de grande relevo da codificação baiana foi o seu artigo 127 que atribuía expressamente ao juiz poder de ordenar diligências ex officio para apurar a verdade dos fatos alegados. ${ }^{108}$ ESPíNOLA deixa claro em seus comentários a sua fonte de inspiração: o artigo 183 da ZPO austríaca de 1895 e a vasta produção doutrinária que a seguiu. Aliás, ESPÍNOLA, demonstrando uma erudição invulgar, cita com abundância a doutrina de vanguarda da época. Para justificar os poderes instrutórios do juiz previsto no artigo 127 do Código do Processo do Estado da Bahia, o autor se respalda nas seguintes referências: CHIOVENDA, Le riforme processuali e le correnti del pensiero del giudice nella ricerca della vera situazione, 1912; LESSONA, La ricerca del vero nei giudizii civili, 1911; KHOLER, 1913, BAHR, Zur Reform des Zivilprozesses, 1912; PLósZ, Die Prozessleitung des des Gerichts nach der neuen ungarischen Ziviprozessordnung, 1912; e MENDELSSOHN-BARTHOLDY, Reform des Zivilprozesswesens, 1913. ${ }^{109}$

EDUARDO ESPÍNOLA refere-se expressamente aos princípios de oralidade e concentração - que também chamou de princípio da verbalidade - ao tratar do Processo Summario acolhido pela codificação baiana. ${ }^{110}$ É interessante notar que embora ESPÍNOLA já tivesse conhecimento da crítica de TISSIER acerca da desnecessidade da previsão de dois modelos procedimentais - sumário e ordinário -, porquanto a simplificação procedimental deveria ser a regra, e não a exceção, o autor baiano preferiu manter a tradicional divisão do procedimento comum. ${ }^{111}$

\footnotetext{
107 ESPÍNOLA, Eduardo. Código do Estado da Bahia Annotado, v.1, p. 497, nota 185.

108 Apesar de o artigo 127 do Código do Processo do Estado da Bahia de 1915 já prever de forma ampla os poderes instrutórios do juiz, chama a atenção o fato de o preceito ser repetido insistentemente pelo Código: arts. 146, 182, 191, 213, 222, 229, 244, 268, e 286.

109 ESPÍNOLA, Eduardo. Código do Estado da Bahia Annotado, v.1, p. 499-501, nota189.

110 ESPÍNOLA, Eduardo. Código do Estado da Bahia Annotado, v. 2, p. 5, nota 1.

111 ESPÍNOLA demonstra ter ciência da discussão sobre a pertinência da divisão do procedimento comum em sumário e ordinário ao citar as propostas de reforma e discussões doutrinárias acerca deste tema travadas na França e Itália na virada do século XIX para o século XX, notadamente o pensamento de TISSIER. ESPÍNOLA, Eduardo. Código do Estado da Bahia Annotado, v.1, p. 498.
} 
Vale ainda mencionar que o Código do Processo do Estado da Bahia não previu a possibilidade de introdução oral da demanda no procedimento sumário, tal como permitia as Ordenações Filipinas, Manuelinas e Afonsinas. O artigo 321 do Código baiano exigia nas aç̧ões summarias uma petição inicial escrita, sem prever exceções, sendo que o mesmo ocorreu em relação ao procedimento sumaríssimo previsto no artigo 331. Todavia, facultava-se ao réu fazer a sua defesa de forma oral logo na primeira audiência, caso entendesse estar preparado para tanto (arts. 323 e 333).

ESPÍNOLA não explicou a razão de ser desta opção legislativa. Coincidentemente, é a mesma opção trilhada pela ZPO austríaca de 1895. No procedimento idealizado por FRANZ KLEIN, a existência de uma fase preparatória escrita Schriftliches Vorverfahren - é essencial para a eficiência do processo.

\subsection{CÓDIGO DE PROCESSO CIVIL DE 1939: O DESCOMPASSO ENTRE A EXPOSIÇÃO DE MOTIVOS E O CÓDIGO}

Existe um descompasso entre a Exposição de Motivos do Código de Processo Civil de1939 e a disciplina do processo civil estabelecida pelo próprio Código. Embora a Exposição de Motivos do CPC de 1939, subscrita pelo então Ministro da Justiça FRANCISCO CAMPOS, estivesse fortemente marcada pela ideologia autoritária do Estado Novo, o Código não revelou um rompimento abrupto com a tradição processual luso-brasileira, e com o modelo liberal de processo.

Nem mesmo em relação aos poderes instrutórios do juiz seria possível afirmar que o CPC de 1939 inovou. Isso porque o Regulamento 737 de 1850 já concedia iniciativas probatórias ao juiz (arts. 181, 209 e 230). Como afirmou MOACYR LOBO DA COSTA, a leitura desses dispositivos basta para demonstrar que o papel de espectador indiferente podia ser desempenhado, como ainda hoje, pelo juiz relapso, mas isso era uma contingência humana e não legal. O Regulamento, porém, armava-o de poderes de atuação no processo, para bem desempenhar sua missão. ${ }^{112}$

MOACYR AMARAL SANTOS afirma que, enquanto na Exposição de Motivos era defendida ardorosamente a prevalência do caráter político sobre o técnico na

112 COSTA, Moacyr Lobo da. Breve notícia histórica do Direito Processual Civil Brasileiro e de sua literatura, p. 35. 
conformação do processo, o Código abraçava um sistema de princípios até certo ponto contrastantes com o caráter autoritário do Estado. Assim, embora tenha reforçado os poderes do juiz na direção do processo, condicionou o exercício desse poder à conformação com as normas processuais (leia-se: contraditório, dever de motivar, adstrição entre pedido e sentença, etc.), de modo que conclui o autor que todos os princípios cardeais do processo dispositivo foram acolhidos pelo Código de $1939 .{ }^{113}$ Havia assim uma duplicidade do legislador, que concebeu o Código de forma autoritária, mas o realizou pautado nos princípios de um modelo liberal.

Esta duplicidade do legislador talvez possa ser explicada pelo fato de que a Exposição de Motivos e o Código não foram obra de uma mesma pessoa. A Exposição de Motivos - que, aliás, não examina com profundidade nenhuma questão de técnicaprocessual - reflete muito bem o pensamento de FRANCISCO CAMPOS, expoente do Estado Novo, ministro e homem de confiança de Getúlio Vargas. O anteprojeto, por sua vez, foi obra de PEDRO BATISTA MARTINS, que, apesar de amigo de FRANCISCO CAMPOS, tal como declarado na própria Exposição de Motivos, foi um dos signatários do Manifesto aos Mineiros, de 24 de outubro de 1943, protesto contra o governo Vargas, de cunho ideológico nitidamente liberal.

Além disso, é curioso notar que os dois jovens advogados que auxiliaram PEDRO BATISTA MARTINS na elaboração do Anteprojeto do CPC de 1939 tinham perfis políticos igualmente contrastantes . O primeiro deles, VICTOR NUNES LEAL ${ }^{114}$ foi Chefe da Casa Civil de Juscelino Kubitschek (1956-1959), que o nomeou para o Supremo Tribunal Federal em 1960, cargo no qual permaneceu até ser aposentado, em 1969, por Costa e Silva (Decreto de 17 de janeiro de1969, combinado com artigo $6^{\circ}$, $\S 1^{\circ}$, do Ato Institucional n. 5 de 1968). O segundo, CARLOS MEDEIROS SILVA, ocupou em 1946 o cargo de Chefe de Gabinete do próprio FRANCISCO CAMPOS, e foi nomeado para o Supremo Tribunal Federal por Castelo Branco em 1965, cargo que ocupou até assumir o cargo de Ministro da Justiça, no governo Castelo Branco em 1966. ${ }^{115}$

Demais disso, nos debates publicados pela Revista Forense por ocasião da entrada em vigor do CPC de 1939, as diferenças entre PEDRO BATISTA MARTINS

\footnotetext{
113 SANTOS, Moacyr Amaral. Contra o processo autoritário. Revista da Faculdade de Direito da Universidade de São Paulo, v. 54, fascículo 2, 1959. p. 220-223.

114 Natural de Carangola-MG, mesma cidade na qual o pai de PEDRO BATISTA MARTINS desempenhara a função de promotor de justiça.

${ }^{115}$ Dados biográficos colhidos no sítio do Supremo Tribunal Federal. Disponível em: www.stf.jus.br.
} 
e FRANCISCO CAMPOS ficaram mais claras. PEDRO BATISTA MARTINS dá especial importância à limitação dos poderes discricionários do juiz por meio do dever de motivação de todas as decisões judiciais. Assim, reconhecido o dever de motivação das decisões judiciais como uma garantia processual, o autor do Anteprojeto do CPC 1939 afirmava não ver pertinência na dicotomia processo acusatório e processo inquisitório, porquanto o mecanismo de controle do arbítrio do juiz pelo dever de motivar era pertinente a ambos os modelos: aliás, com franqueza, por mais que reflita, não vejo diferença, no que diz respeito ao arbítrio, entre o regime dispositivo e o inquisitório. Naquele, o juiz poderá, igualmente, conceder medidas violentas e vexatórias (...). ${ }^{116}$

Nestes termos, para PEDRO BATISTA MARTINS, toda discussão de fundo ideológico que se travava em torno do aumento dos poderes do juiz era inócua. Estando a discricionariedade do juiz na condução do processo limitada pelo dever de motivar suas decisões, as partes estariam suficientemente protegidas de eventuais arbitrariedades do magistrado. Assim, afirmava PEDRO BATISTA MARTINS que as disputas relativas às vantagens da consagração do princípio da atividade do juiz são, por conseguinte, puramente acadêmicas e destituídas de qualquer alcance prático. ${ }^{117}$

Em sentido diametralmente oposto estava o discurso de FRANCISCO CAMPOS. Segundo o então Ministro da Justiça, a opção pelo sistema da concentração e da oralidade era uma consequência necessária do regime instaurado em 10 de novembro de 1937; tal escolha tinha sido uma opção de ordem política, e não representava uma questão técnica a ser resolvida entre técnicos, mas sim uma reivindicação da massa social. ${ }^{118}$

Em Portugal também poderia ser levantada a mesma discussão: a defesa do processo oral e o aumento dos poderes do juiz, defendidos por José Alberto dos Reis, são medidas acolhidas nas reformas da década de 1930, sob o regime de Salazar ele próprio um catedrático de Coimbra, feito doutor por José Alberto dos Reis.

$\mathrm{Na}$ Alemanha a questão pareceu suscitar maior interesse na academia. A Emminger Nouvelle, concebida sob a República de Weimar, foi transformada numa expressão do nacional-socialismo no campo do direito processual, mas é mantida até hoje, em plena democracia, sem que lhe seja atribuída a pecha de autoritária.

\footnotetext{
${ }^{116}$ MARTINS, Pedro Batista. Em defesa do Ante-Projeto de CPC. In: Processo Oral. Rio de Janeiro: Forense, 1940. p. 237-238.

117 MARTINS, Pedro Batista. Em defesa do Ante-Projeto de CPC, p. 237-238.

118 CAMPOS, Francisco. Reforma do Processo Civil. In: Processo Oral. Rio de Janeiro: Forense, 1940. p. 188.
} 
Todavia, a honestidade impõe o reconhecimento de que este tópico ainda merece maior reflexão. A conclusão disponível até o momento é de que se trata de uma infeliz coincidência histórica, de modo que é espúria a tentativa de associar um modelo oral de processo a regimes autoritários.

\subsection{CONCLUSÃO PARCIAL}

O princípio da oralidade relacionado à teoria da prova é uma construção do processo civil contemporâneo. No processo civil romano é apenas possível falar em oralidade como prevalência da palavra oral em detrimento da forma escrita, determinada por fatores extrínsecos.

Justificar a oralidade no processo civil romano com base nos valores atribuídos hodiernamente ao processo oral importa realizar uma conexão espúria entre ação humana e fenômeno analisado.

A oralidade no processo do período da monarquia etrusca era fortemente determinada pela ritualística religiosa. A razão de ser desta oralidade foge à nossa compreensão, pois está relacionada a uma mentalidade determinada por elementos transcendentais.

No período das ações da lei, a audiência era o palco dos oradores e a oralidade não contribuiu para a melhor apuração e valoração dos fatos. Já no período formular, com a consolidação do processo de laicização do direito, abriu-se caminho para a racionalização da matéria da prova, mas mesmo assim não é possível falar que a oralidade no processo tenha adquirido a carga axiológica que possui hoje.

Por fim, no sistema da extraordinaria cognitio, verifica-se a introdução no processo de elementos de prova legal a partir do Baixo Império. Esses elementos não chegaram a tarifar de modo absoluto e matemático a valoração da prova, mas tolheram parcialmente a livre convicção do julgador. Por outro lado, neste período verifica-se que a prevalência da palavra oral paulatinamente cedeu espaço para a forma escrita, preconizando o modo de ser do processo próprio do ius commune.

O apego às opções técnicas do passado importa um obstáculo significativo. Basta ver a ausência de contato direto do julgador com a prova testemunhal, regra geral em quase todos os períodos analisados neste estudo. Da figura do enqueredor 
que marcou a oitiva de testemunhas nas Ordenações Afonsinas, Manuelinas e Filipinas, ao Juiz Municipal instrutor a partir da Disposição Provisória de 1832, e a posterior delegação dos atos de instrução ao Juiz Substituto até o início da República, existe uma mesma ideia subjacente: instruir e julgar são atividades plenamente destacáveis.

Neste aspecto, não se pode aceitar sem ressalvas a afirmação de que a Disposição Provisória de 1832 teria antecipado muitas das ideias dos pregoeiros da oralidade, atribuindo-se assim um caráter vanguardista e inovador ao legislador brasileiro. As reformas processuais do século XX pautadas na oralidade fundaram-se num trabalho de seleção e síntese de técnicas processuais aprimoradas ao longo do século XIX. A Disposição Provisória de 1832, a despeito de moderna, guarda sintonia com as tendências do processo civil continental da época, não se podendo afirmar que estava um século a frente de seu tempo.

Uma ruptura com a tradição processual lusitana pode ser observada no Código do Processo do Estado da Bahia, de 1915, fortemente influenciado pela ZPO austríaca de 1895. É de se lamentar, todavia, o fato de ter exercido pouca influência na legislação posterior, e o fato de não haver dados acerca do impacto deste código sobre a prática forense baiana da época.

Outro elemento que precisa ser considerado é a indevida associação de novas tendências técnicas processuais a determinadas ideologias políticas. Aliás, o descompasso entre a Exposição de Motivos do CPC de 1939 com o próprio Código já revela que tal apropriação de ideias é espúria. 


\section{CONSTRUÇÕES DOGMÁTICAS DA ORALIDADE}

\subsection{NEGAÇÃO DO VALOR APRIORÍSTICO DA ORALIDADE (ADOLF WACH)}

Oralidade para WACH é a imediação na percepção da substância do processo pelo juiz, de modo que somente aquilo que for fruto dessa imediação sirva de fundamento para a decisão. ${ }^{119}$ De outro lado, a escritura seria a prevalência absoluta daquilo que foi documentado, de modo que o conteúdo do processo e o conteúdo dos autos sejam idênticos. ${ }^{120}$

O grande mérito de WACH foi a superação do fanatismo da oralidade e do formalismo da oralidade (Mündlichkeits-fanatismus e Mündlichkeitsformalismus ${ }^{121}$ ), presente na obra de grande parte da doutrina de sua época. Um dos autores “fanáticos” pela oralidade foi ADOLF LEONHARDT. Para este autor, considerado o pai do Código de Processo Civil de Hannover de 1850, a escolha entre um procedimento escrito ou oral deveria ser uma questão central nos trabalhos de elaboração do novo sistema processual que viria a se consolidar na ZPO de 1877. Segundo ele, o legislador deveria escolher entre a adoção de um procedimento escrito ou oral, sendo que um processo meio escrito e meio oral não poderia ser admitido. ${ }^{122}$

\footnotetext{
${ }^{119}$ Mündlichkeit soll sein die Unmittelbarkeit der Wahrnehmung des Processstoffs durch der erkennenden Richter. Sie sagt, dass nur das unmittelbar von RichterWahrgenommene Urtheilsgrundlage ist. Em tradução livre: "A oralidade deve ser vista como a possibilidade de apreensão imediata do material processual por parte do juiz. Ela determina que apenas aquilo que o julgador apreende de forma imediata pode ser tido como fundamento de sua decisão". WACH, Adolph. Mündlichkeit und Schriftlichkeit. In: über die Reichs-Civilprocessordnung. Bonn: Adolf Marcus, 1879. p. 1.

${ }^{120}$ Schriftlichkeit ist das absolute Beurkundungsprincip. Sie sagt dass Processinhalt und Akteninhalt sich decken. Em tradução livre: "A escrita é um princípio de registro absoluto, na medida em que garante que o conteúdo do processo e o conteúdo dos atos processuais sejam sempre os mesmos”. WACH, Adolph. Mündlichkeit und Schriftlichkeit, p. 1.

${ }^{121}$ Em 1879 WACH usou a expressão Mündlichkeits-fanatismus para fazer referência aos processualistas que pregavam a oralidade pura. WACH, Adolph. Mündlichkeit und Schriftlichkeit, p. 3. Em 1895, o autor usou tanto a expressão Mündlichkeits-fanatismus como Mündlichkeits-formalismus para se referir a essa corrente de pensamento. WACH, Adolph. Mündlichkeit im österreichischen Civilprocess-Entwurf. Wien: Manz, 1895. p. 4.

${ }^{122}$ Der Gesetzgeber muß sich entscheiden, entweder Schriftlichkeit oder Mündlichkeit des Verfahrens, wenn diese, dann volle Mündlichekeit, kein halb schriftliches, halb mündliches Verfahren. Em tradução livre: "O legislador precisa se decidir ou pela característica escrita, ou pela característica oral do processo. Caso venha a ser escolhida esta ultima, então que o seja de modo pleno, e não de forma mista, com parte marcada pela
} 
WACH criticava tais exageros, afirmando que tais autores, ao atribuírem um valor excessivo à oralidade, transformavam sua realização plena em um fim em si mesmo. Na concepção de WACH, a dicotomia oralidade-escritura não deveria ser pensada em termos de princípios, mas sim de conveniência. ${ }^{123}$ Deveras, o autor chega a afirmar que a oralidade não seria um princípio e que sua realização estrita deveria ceder espaço para interesses superiores. ${ }^{124}$

WACH chega a destacar que a oralidade pura é irrealizável. Na concepção dos “fanáticos” pela oralidade, nenhuma dilação entre a discussão oral, colheita da prova e julgamento seria possível. Além disso, levando-se a oralidade às últimas consequências, WACH afirma que não se poderia admitir nem mesmo um grau recursal, dada a quebra da imediação. ${ }^{125}$

Nestes termos, a grande relevância da concepção de WACH acerca da oralidade reside na negação da superioridade a priori da forma oral sobre a forma escrita. A forma dos atos processuais depende de um juízo de conveniência ou de adequação - ou seja, está fora do campo dos princípios processuais. ${ }^{126}$

\subsection{ORALIDADE E OS PODERES DO JUIZ NO PENSAMENTO DE FRANZ KLEIN}

A oralidade no pensamento de FRANZ KLEIN está intimamente relacionada com o conceito de poderes do juiz na direção do processo. A concepção do jurista austríaco deve ser interpretada tendo-se em vista a realidade do Império Austro-

escrita e parte marcada pela oralidade”. apud LEIPOLD, Dieter. Oral and Written Elements within the Introductory Phase of Civil Proceedings, p. 74.

${ }^{123}$ Die Frage der relevanten Erscheinungsform der Processinhalts ist nicht Principenfrage, sondern Frage der Zweckmässigkeit. ist. Em tradução livre: “A questão da forma de manifestação do conteúdo processual não é de caráter principiológico, mas sim de adequação a determinados fins”. WACH, Adolph. Mündlichkeit und Schriftlichkeit, p. 1-2; Mündlichkeit im österreichischen Civilprocess-Entwurf, p. 4.

${ }^{124}$ So hat man weise höheren Interessen die folgerichtige Durchführung des sogenannten Princips der Mündlichkeit geopfert. Und da gilt es nicht konsequenter sein zu wollen, als es das Gesetz ist, ihm nicht formalistiche Folgerungen eines sogenannten Princips zu imputieren, welches keines Princip ist. Em tradução livre: "Sabiamente, deu-se preferência a interesses superiores e colocou-se em um segundo plano a concretização deste chamado princípio da oralidade. E, neste plano, não cabe exigir mais do que a lei oferece, imputando consequências formalistas ao valor da oralidade - a qual, vale dizer, sequer é um princípio.” WACH, Adolph. Mündlichkeit und Schriftlichkeit, p. 38.

${ }^{125}$ WACH, Adolph. Mündlichkeit und Schriftlichkeit, p. 3.

${ }^{126}$ Auf die Frage nach der Form der processualischen Handlungen lässt uns die Zweckbestimmung des Processes ohne der doch bestimmte Antwort. Die Form ist die beste, welche die zweckgemässeste ist. Em tradução livre: "Para a pergunta sobre a melhor forma de realização dos atos processuais, a adequação aos fins do processo não oferece qualquer resposta definitiva. A forma melhor será aquela mais adequada à conveniência aos objetivos processuais”. WACH, Adolph. Mündlichkeit und Schriftlichkeit, p. 2. 
Húngaro no final do século XIX, na qual a prática forense era fortemente marcada por um procedimento pautado pela longa troca de manifestações escritas entre as partes, sem intervenções mais enérgicas por parte do juiz.

Assim, a oralidade na obra de FRANZ KLEIN é uma reação aos excessos da prática forense de sua época, e em grande medida está permeada por uma visão reformista, pautada na concentração de fases procedimentais e na consequente aceleração do procedimento.

\subsection{ORALIDADE NO PENSAMENTO DE GIUSEPPE CHIOVENDA}

A definição de oralidade mais arraigada na doutrina brasileira certamente é a de CHIOVENDA, para quem a oralidade é um princípio fundamental do processo segundo o qual as deduções das partes devem fazer-se a viva voz na audiência, isto é, no momento e lugar em que o juiz se assenta para ouvir as partes e dirigir a marcha da causa, estreitamente conexa com os seguintes princípios: a) imediação na relação entre o juiz e as pessoas cujas declarações deve apreciar; b) identidade das pessoas físicas que constituem o juiz durante a condução da causa; c) concentração do conhecimento da causa num único período (debate) a desenvolver-se numa audiência ou em poucas audiências contíguas; e d) irrecorribilidade das interlocutórias em separado. $^{127}$

\subsubsection{A INFLUÊNCIA DA CONCEPÇÃO CHIOVENDIANA DE ORALIDADE NA DOUTRINA BRASILEIRA}

A influência das ideias de CHIOVENDA sobre o assim chamado princípio da oralidade na doutrina brasileira foi tão forte que desde as primeiras manifestações sobre o tema no início do século passado até as publicações dos dias de hoje reproduzem ipsis litteris, sem maior espírito crítico, os postulados do autor.

127 CHIOVENDA, Giuseppe. Instituições de Direito Processual Civil. v. I. 3. ed. Tradução de J. Guimarães Menegale. São Paulo: Saraiva, 1969. n.16-A. p. 52; e v. 3. 2. ed. São Paulo: Saraiva, 1965. n. 309. p. 50-55; também em CHIOVENDA, Giuseppe. Relazione su progetto di riforma del procedimento elaborato dalla Coomissione per il dopo guerra. In: Saggi di Diritto Processuale. v. II. Milano: Giuffrè, 1993. 
Na edição de maio de 1938 da Revista Forense, dedicada ao tema da oralidade no processo civil, praticamente todos os artigos de autores brasileiros reproduzem, sem variações dignas de nota, o pensamento de CHIOVENDA. É o caso, por exemplo, dos textos de FRANCISCO MORATO, ${ }^{128}$ LUís MACHADO GUIMARÃEs, ${ }^{129}$ e GUILHERME ESTELITA. ${ }^{130}$

Exceção honrosa é VICTOR NUNES LEAL, para quem, inevitavelmente, a construção teórica de CHIOVENDA acerca da oralidade tornar-se-ia ultrapassada num futuro não muito distante de sua época.

Daqui a cincoenta anos nós é que seremos batidos como reacionários. Quando os modernos de 1990 exhumarem e destroçarem sacrilegamente os ossos de CHIOVENDA, nós também arrancaremos os cabelos brancos de desespêro clamando: Esses moços de hoje estão doidos! Já não temos mais juristas... ${ }^{131}$

Deveras, um dos objetivos desta dissertação é questionar a hegemonia da definição chiovendiana de oralidade na doutrina brasileira, e demonstrar como o conceito hermético apresentado por CHIOVENDA engessou as discussões acerca da formatação do procedimento, ao tratar a oralidade como princípio processual.

\subsubsection{MOTIVAÇÃO POLÍTICA DE CHIOVENDA EM SUSTENTAR A PREVALÊNCIA DA ORALIDADE EM SUA CONCEPÇÃO CONTEMPORÂNEA NO PROCESSO CIVIL ROMANO}

CHIOVENDA defendia a prevalência do princípio da oralidade em seu sentido contemporâneo no processo civil romano por razões políticas, visando evitar possíveis rejeições de suas propostas de reforma do processo civil, que, de modo não confessado, inspiravam-se em experiências austríacas.

A oralidade no processo civil é um dos temas centrais de CHIOVENDA, tanto em seus trabalhos acadêmicos, como em suas propostas legislativas

\footnotetext{
${ }^{128}$ MORATO, Francisco. A Oralidade. Revista Forense. Rio de Janeiro, p. 11-18, maio 1938.

129 GUIMARÃES, Luís Machado. O Processo Oral e o Processo Escrito. Revista Forense. Rio de Janeiro, p. 30-37, maio 1938. O autor afirma que na doutrina brasileira JOÃO CARNEIRO DE SOUZA BANDEIRA já havia exaltado o valor da oralidade antes mesmo de CHIOVENDA. Todavia, equivoca-se o autor acerca da data da primeira manifestação de CHIOVENDA sobre o tema.

130 ESTELITA, Guilherme. O Processo Oral e sua Adoção no Brasil. Revista Forense. Rio de Janeiro, p. 115-117, maio 1938.

${ }^{131}$ NUNES LEAL, Victor. Ignorância, rotina e chicana - os três maiores inimigos do Processo Oral, p. 121.
} 
para a reforma do processo civil italiano. Ao tratar do tema, CHIOVENDA afirma que, do ponto de vista histórico, existem duas espécies de oralidade. A primeira é aquela própria dos povos primitivos, e deve-se a causas extrínsecas ao processo, como a ignorância da palavra escrita e o costume de tratar dos assuntos judiciais em assembleia pública. Esta espécie não se confunde com processo oral em termos modernos, relacionado a uma concepção científico-racional da prova, mas consiste na mera prevalência da forma oral em detrimento da escrita. A segunda, ao contrário, é a oralidade vinculada ao ofício do juiz e à função da prova no processo. ${ }^{132}$

Até este ponto a opinião do autor converge com as ideias desenvolvidas na parte histórica desta dissertação: não se pode confundir a oralidade própria do processo dos povos da Antiguidade com a concepção moderna de oralidade estreitamente ligada à teoria prova. A divergência surge apenas quando CHIOVENDA sustenta que o processo romano teria conhecido a oralidade nas duas acepções acima expostas. $^{133}$

\subsubsection{ARGUMENTOS UTILIZADOS POR CHIOVENDA PARA SUSTENTAR A PREVALÊNCIA DA ORALIDADE EM SUA ACEPÇÃO MODERNA NO PROCESSO CIVIL ROMANO}

Para sustentar a prevalência da oralidade relacionada à teoria da prova no processo civil romano de época clássica, CHIOVENDA cita em primeiro lugar a célebre passagem recolhida no capítulo II, Livro XIV, das Noites Áticas de Aulo Gélio. ${ }^{134}$ Conforme desenvolvido em tópico abaixo, esta fonte literária apenas autoriza a se falar na ausência de regras bem estruturadas sobre o ônus da prova no referido período.

Em segundo lugar, o autor cita as obras de Cícero. ${ }^{135}$ Todavia, conforme desenvolvido em tópico próprio, a obra de Cícero, assim como de outros oradores, demonstra que a prova no período clássico pertencia ao campo da retórica, corroborando a tese de ausência de regras de ônus da prova em termos jurídicos.

\footnotetext{
132 CHIOVENDA, Giuseppe. Sul rapporto fra le forme del procedimento e la funzione della prova (l'oralità e la prova). In: Saggi di Diritto Processuale. v. II. Milano: Giuffrè, 1993. p. 210.

133 CHIOVENDA, Giuseppe. Sul rapporto fra le forme del procedimento e la funzione della prova, p. 210.

134 CHIOVENDA, Giuseppe. Sul rapporto fra le forme del procedimento e la funzione della prova, p. 210.

135 CHIOVENDA, Giuseppe. Sul rapporto fra le forme del procedimento e la funzione della prova, p. 211.
} 
Todavia, ainda que se reconheça a polêmica quanto à interpretação destas fontes literárias acima mencionadas para afirmar a existência ou não de regras sobre o ônus da prova no referido período, há de se notar que estes elementos não são suficientes para afirmar a prevalência do princípio da oralidade no processo civil romano relacionada com a função da prova.

Quanto ao período pós-clássico, CHIOVENDA cita um rescrito do imperador Adriano (76-138 d.C.), endereçado a um certo Valerium Verum. Nesta passagem encontra-se uma recomendação imperial para que o julgador não se atenha a uma única espécie de prova, mas julgue de acordo com seu próprio convencimento e com aquilo que considerar satisfatoriamente provado (D. 22.5.3.2 Hoc ergo solum tibi rescribere possum summatim non utique ad unam probationis speciem cognitionem statim alligari debere, sed ex sententia animi tui te aestimare oportere, quid aut credas aut parum probatum tibi opinaris). Ora, esta passagem não autoriza afirmar que o processo romano adotava a oralidade como princípio vinculado à teoria da prova, mas apenas reafirma um de seus pressupostos, qual seja, o livre convencimento do juiz.

O melhor argumento usado por CHIOVENDA é igualmente um rescrito de Adriano, no qual é afirmado que a força do depoimento prestado pela testemunha presente não é a mesma do depoimento prestado pela testemunha que não está presente, cabendo ao juiz atribuir-lhes o devido valor (D. 22.5.3.4 Alia est auctoritas praesentium testium, alia testimoniorum quae recitari solent: tecum ergo delibera, ut, si retinere eos velis, des eis impendia). ${ }^{136}$

Embora seja provável que Adriano pretendia dizer que o testemunho prestado de viva voz perante o juiz guarda em si um valor intrínseco maior, exprimindo uma das ideias centrais do princípio da oralidade, literalmente é apenas afirmado que o valor desta não é o mesmo do depoimento da testemunha que não se faz presente. Ou seja, a rigor, a passagem apenas autoriza extrair a regra do livre convencimento do juiz.

Demais disso, deste rescrito citado por CHIOvENDA pode se extrair uma conclusão diametralmente oposta à do autor. A passagem revela que era possível a produção da prova testemunhal por escrito, sem a presença da testemunha. Assim, ainda que o valor da prova testemunhal por escrito não seja o mesmo daquela produzida de viva

${ }^{136}$ CHIOVENDA, Giuseppe. Sul rapporto fra le forme del procedimento e la funzione della prova , p. 211. 
voz, admite-se regularmente a prova testemunhal produzida sem qualquer contato direto do juiz com as partes.

Mas o que chama a atenção não é tanto a conclusão do autor. Deveras as fontes do direito processual civil romano são lacunosas, e as conclusões nos estudos sobre os direitos da Antiguidade são, independentemente do esmero e da capacidade do pesquisador, meras conjecturas. O que é incomum é o modo enfático com que CHIOVENDA sustenta sua tese, que causa certa estranheza ao pesquisador, levando-o a imaginar que possivelmente o autor teria outras razões além do mero estudo histórico para defender as origens latinas do princípio da oralidade no processo.

\subsubsection{A MOTIVAÇÃo POLÍTICA NO PENSAMENTO DE CHIOVENDA}

CHIOVENDA afirmava a prevalência da oralidade no direito romano como um modo de desautorizar possíveis rejeições à adoção de um processo oral na Itália inspirada nos moldes da Zivilprozessordnung austríaca de 1895, delineada por KLEIN.

Não se pode esquecer que a Itália e o Império Austro-Húngaro entraram em conflito durante a Primeira Guerra Mundial, fato que certamente influenciou negativamente a discussão de uma reforma processual fortemente inspirada no modelo austríaco $^{137}$.

Este aspecto do pensamento de CHIOVENDA transparece numa entrevista sobre as reformas processuais publicada no jornal La Tribuna, em Roma, em 5 de fevereiro de 1922. Ao ser indagado se acreditava que seria bem acolhida uma lei processual baseada no modelo austríaco, CHIOVENDA responde enfaticamente que o processo oral não está atrelado a nenhuma nação, e que o processo romano já adotava em sua plenitude os postulados da oralidade. ${ }^{138}$

\footnotetext{
137 O governo italiano declarou oficialmente guerra contra o Império Austro-Húngaro em 23 de maio de 1915. O conflito resultou na anexação das regiões de Trento, Bolzano, Istria e Dalmácia pela Itália ao fim da Primeira Guerra Mundial.

${ }^{138}$ Il processo orale non è austriaco nè germanico; il processo orale è inglese, è svizerro, è francese, ma sopratutto è romano. Il processo romano nel maggior fiore della civiltà imperiale, era prettamente orale, immediato e concentrato: poichè vi è un'intima necessaria connessione fra l'oralità del procedimento e il principio della libera prova, del libero convincimento del giudice, che dominava il giudizio romano. CHIOVENDA, Giuseppe. Sulla riforma del Processo Civile. Intervista di Roberto Bisceglia. In: Saggi di
} 
Demais disso, o silêncio de CHIOVENDA sobre o sistema processual civil austríaco da Zivilprozessordnung de 1895, assim como em relação aos escritos de KLEIN em geral, é algo que causa uma certa estranheza, levando-se em consideração que o pensamento destes juristas acerca da imediação e da oralidade no processo civil são coincidentes em inúmeros pontos. Chiovenda no fu, purtroppo, ma avrebbe voluto e dovuto essere il Klein italiano, sintetizou CARNELUTTI. ${ }^{139}$

Não obstante, CHIOVENDA apenas analisou com maior atenção o sistema austríaco de processo oral num texto datado de 1901, sendo que em sua vasta produção bibliográfica posterior este sistema e a obra de KLEIN são citados apenas en passant, sem maior destaque e profundidade na análise. ${ }^{140}$

Daí surge a dúvida sobre qual seria a razão do silêncio de CHIOVENDA sobre uma experiência vitoriosa de reforma do processo civil que reflete em grande parte suas próprias convicções e, que, segundo reconheceu o próprio autor em 1901, mereceria a máxima atenção. ${ }^{141}$

O que parece estar mais ou menos claro é que CHIOVENDA, tanto ao afirmar que o processo romano era marcado pela oralidade em sua plenitude, inclusive no que se refere à teoria da prova, como ao silenciar acerca da experiência austríaca da $Z P O$ de 1895, o fez preocupando-se com questões outras que a mera coerência de pensamento no âmbito acadêmico.

Sabe-se que CHIOVENDA foi signatário do Manifesto Croce ${ }^{142}$ de $1^{\circ}$ de maio de 1925, e que sua relação com o governo de Benito Mussolini esteve marcada

Diritto Processuale Civile, v. 3. Milano: Giuffrè, 1993. p. 398. No mesmo sentido, a denotar o caráter político da tese da plenitude da oralidade no processo romano: Io credo che sia dovere di buone cittadini e di buoni scienziati affermare solennemente e popolarizzare con ogni mezzo questa idea: che l'oralità nel processo civile, lungi dall'esser un prodotto della razza germanica, fu anzi una squisita caratteristica del diritto romano (...).CHIOVENDA, Giuseppe. La riforma del procedimento civile. In: Saggi di Diritto Processuale Civile. v. 3. Milano: Giuffrè, 1993. p. 388-389.

${ }^{139}$ CARNELUTTI, Francesco. Addio, Chiovenda. Rivista di Diritto Processuale, Padova, Cedam, v. 3, Parte I, 1948. p. 121.

${ }_{140}$ CHIOVENDA, Giuseppe. Le forme nella difesa giudiziale del diritto. In: Saggi di Diritto Processuale. v. I. Milano: Giuffrè, 1993. p. 370-371. A constatação é de CIPRIANI, Franco. Nel centenario del Regolamento di Klein (Il processo civile trà libertà e autorità). Rivista di Diritto Processuale, Padova, Cedam, n. 4, 1995. p. 971, nota 13.

${ }^{141}$ Menziono a questo proposito il nuovo regolamento processuale austriaco, entrato in vigore il $1^{\circ}$ gennaio 1898, che essendo l'ultima importante espressione della legislazione processuale, preparata da un lungo periodo d'elaborazione scientifica, merita la massima attenzione. CHIOVENDA, Giuseppe. Le forme nella difesa giudiziale del diritto, p. 370 .

${ }^{142}$ O Manifesto Croce, redigido por Benedetto Croce e publicado originalmente no jornal Il Mondo de $1^{\circ}$ de maio de 1925, foi uma resposta dos intelectuais antifascistas ao Manifesto dos Intelectuais Fascistas, de autoria de Giovanni Gentile. É preciso registrar que a assertiva de CIPRIANI (CIPRIANI, Franco. Giuseppe 
por incidentes não amistosos. ${ }^{143}$ Entretanto, tais dados pouco contribuem para revelar o significado de seu silêncio quanto ao sistema processual austríaco e da defesa enfática por ele empreendida em favor da prevalência da oralidade em seu sentido pleno no processo civil romano.

Significativo é o reconhecimento por parte do próprio CHIOVENDA, em 1919, no que tange à dificuldade de aceitação pela opinião pública da época da adoção de um modelo processual de origem austríaca: L'imitazione della legge austriaca incontrerà però prevenzioni ed avversioni di vario genere, come legge straniera e come legge austriaca in particolare. ${ }^{144}$

Assim, a tese segundo a qual o processo civil romano teria conhecido a oralidade relacionada à teoria da prova assume tal relevo no discurso de CHIOVENDA que acaba por evidenciar não ser desinteressada a conclusão do autor.

Deveras, sua afirmação no sentido de que il moderno processo austriaco e germanico è di gran lunga più romano e latino del processo italiano attuale $e^{145}$ revela que o foco de CHIOVENDA não é a metodologia da pesquisa histórica, e sim a identificação de fatores de legitimação para sua proposta de reforma processual. Em outras palavras, o autor imprime uma acepção notadamente contemporânea ao processo civil romano como forma de justificar sua proposta de reforma, sem se preocupar em descrever como efetivamente se desenvolvia o processo na Antiguidade. ${ }^{146}$

Chiovenda, il Manifesto Croce e il Fascismo. Rivista di Diritto Civile, Padova, Cedam, ano XLI, n. 1, 1995. p. 121.) no sentido de que CHIOVENDA teria sido o único processualista entre os signatários do Manifesto Antifascista é uma meia verdade. O nome de CALAMANDREI aparece nas publicações posteriores do Manifesto (Il Mondo, 10 e 22 de maio de 1925), ao lado de outros juristas de renome, tais como ARANGIORUIZ, FRANCESCO MESSINEO e SIRO SOLAZZI. Deveras, a própria publicação ressalva a existência de muitos outros signatários, tendo sido estampados apenas os nomes mais conhecidos pelo público.

${ }^{143}$ Exemplo disso é o indeferimento, pela Presidência do Conselho de Ministros, em 3 de maio de 1928, do pedido de CHIOVENDA para ministrar palestras na Universidade de Barcelona. O convite havia sido feito pelo então ministrante de direito processual civil naquela universidade, José R. Xirau, por ocasião da publicação da tradução espanhola da monografia La condanna nelle spese giudiziali. Tratando-se de evento estritamente acadêmico, é de causar espanto o indeferimento do pedido, que pode ser entendido como uma retaliação pelo posicionamento político contrário ao regime. A obrigatoriedade de se requer autorização ao Ministero della Pubblica Istruzione até mesmo para participar de um evento sobre direito processual civil é um pequeno retrato do regime totalitário no cotidiano acadêmico. A narrativa desse incidente é feita por CIPRIANI, em CIPRIANI, Franco. Giuseppe Chiovenda, il Manifesto Croce e il Fascismo, p. 121-124.

${ }^{144}$ CHIOVENDA, Giuseppe. Relazione su progetto di riforma del procedimento elaborato dalla Coomissione per il dopo guerra, p. 23.

145 CHIOVENDA, Giuseppe. Relazione su progetto di riforma del procedimento elaborato dalla Coomissione per il dopo guerra, p. 26.

${ }^{146}$ Nesta linha, é expressiva a explicação de METZGER sobre o uso de conceitos contemporâneos no estudo do processo civil romano pelos juristas alemães do século XIX: The easiest explanation is that when writers of the past found a gap in the evidence on procedure, the simply supplied an idea from the modern law. This would explain why some Roman procedure seems to reflect nineteenth-century German writers, who were 
A relevância prática desta discussão acerca das motivações políticas de CHIOVENDA consiste em dar a devida dimensão para as afirmações doutrinárias do autor acerca da oralidade enquanto princípio processual, as quais ainda reverberam com força na doutrina brasileira.

O cenário político da época influenciou CHIOVENDA a estabelecer sua definição doutrinária acerca da oralidade como um conceito central em sua obra. A consciência desta determinante política é importante para que a obra de CHIOVENDA seja lida de forma adequada, de modo a evitar que sejam transpostas para a atualidade definições doutrinárias comprometidas com fatores políticos que não mais existem.

\subsection{SIGNIFICADOS DA ORALIDADE PARA MAURO CAPPELLETTI}

A oralidade no pensamento de MAURO CAPPELLETTI foi desenvolvida na obra La testimonianza della parte nel sistema dell'oralità - Contributo alla teoria della utilizzazione probatoria nel sapere delle parti ne processo civile ${ }^{147}$.

Nesta obra, o autor sustenta que a oralidade possui um significado primário, relacionado à livre apreciação da prova testemunhal e das declarações das partes, e um sentido secundário, que diz respeito à possibilidade de o juiz exigir das partes esclarecimento oral sobre os fatos declarados como fundamentos de suas pretensões.

Conforme desenvolvido abaixo, pode-se afirmar que o sentido primário é abraçado pelo direito brasileiro, que adota o sistema da livre apreciação das provas (art. 332, CPC), ao passo que o sentido secundário encontra guarida no artigo 342 do CPC, que trata do depoimento pessoal.

seeking to reform their own laws and institutions. METZGER, Ernest. Roman Judges, Case Law, and Principles of Procedure, p. 246.

${ }^{147}$ CAPPELLETTI, Mauro. La testimonianza della parte nel sistema dell'oralità - Contributo alla teoria della utilizzazione probatoria nel sapere delle parti ne processo civile. Milano, Giuffrè, 1974. 


\section{ORALIDADE COMO REGRA TÉCNICA E NÃO COMO PRINCÍPIO PROCESSUAL}

TARUFFO afirma a existência de dois mitos sobre a oralidade. O primeiro é aquele que proclama o princípio da oralidade como uma espécie de panaceia para todos os males do processo civil. É o que TARUFFo denomina de “mito positivo” da oralidade. ${ }^{148} \mathrm{O}$ outro - o mito negativo - é aquele segundo o qual a forma escrita no processo é algo ruim e indesejável per se. Essas afirmações correntes na doutrina decorrem da concepção de oralidade enquanto princípio processual.

Princípios processuais são dados exteriores à ciência processual, constituindo os pilares desta, ligando-a a um ramo mais amplo, que é o direito público. Já as regras técnicas do processo são meros reflexos, no plano técnico, das ideias que os princípios processuais representam; são dados internos do próprio sistema processual, e não atuam como pilares sobre os quais a ciência processual se apoia. ${ }^{149}$ Nestes termos, a oralidade não seria um princípio processual, mas uma mera regra técnica do processo. ${ }^{150}$

\footnotetext{
${ }^{148}$ TARUFFO, Michele. Orality and writing as factors of efficiency in civil litigation. In: CARPI, Federico; ORTELLS, Manuel (Org.). Oralidad y Escritura en un Proceso Civil Eficiente (Oral and Written Proceedings: Efficiency in Civil Procedure). v. I - Ponencias generales e informes nacionales (General reports and national reports). València: International Association of Procedural Law (IAPL), Universitat de València, 2008. p. 185. PÉREZ-RAGONE e PALOMO VELÉZ também falam em mito da oralidade ao se referirem à supervalorização da oralidade em detrimento da escritura. PÉREZ-RAGONE, Álvaro; PALOMO VÉLEZ, Diego. Oralidad y prueba: comparación y análisis crítico de las experiencias reformadoras del proceso civil en Alemania y España. Revista de Derecho de la Pontificia Universidad Católica de Valparaíso, n. XXXII, Valparaíso, 2009. p. 364, nota 1.

149 DINAMARCO, Cândido Rangel. Instituições de Direito Processual Civil. 3. ed. v. 1. São Paulo: Malheiros, 2003. p. 192-196. Discutir com maior profundidade a distinção entre princípio processual e regra técnica do processo fugiria ao objetivo da presente dissertação. Assim, considerar-se-á como suficiente e válida a definição supra citada apresentada por CÂNDIDO DINAMARCO. É interessante notar que a assertiva segundo a qual a oralidade não é um princípio processual possui profundas raízes históricas que, ao menos na doutrina em língua alemã, remontam à WACH, cf. WACH, Adolph. Mündlichkeit und Schriftlichkeit, p. 38. De outro lado, nos países ibéricos e na América Latina a influência de CHIOVENDA, que arrolava com destaque a oralidade entre os princípios fundamentais do processo, foi mais forte. CHIVENDA, Giuseppe. Instituições de Direito Processual Civil. v. I, p. 52.

${ }^{150}$ DINAMARCO afirma expressamente que a oralidade, embora possa ser considerada uma regra técnica de grande importância e prestígio, rigorosamente não é um princípio processual. DINAMARCO, Cândido Rangel. Instituições de Direito Processual Civil, v. 1, cit., p. 196.
} 
Todavia, DINAMARCo entende que mesmo assim seria conveniente continuar a designar como princípio certas regras técnicas do processo, tais como a oralidade, para evitar inúteis discrepâncias verbais com a doutrina em geral. ${ }^{151}$

Mas há de se notar que abandonar a designação princípio da oralidade traz a vantagem de pôr em evidência alguns desvios de perspectiva sobre a oralidade no processo particularmente arraigados nas doutrinas ibérica e latino-americana.

CARLOS ALBERTO ALVARO DE OLIVEIRA afirma que a oralidade é tratada pela doutrina tradicional como uma questão de princípio e não como uma técnica, o que acaba levando a uma distorção de perspectiva. Se determinado instrumento não é considerado precipuamente como meio e portanto do ponto de vista estritamente técnico, mas como elemento norteador da estruturação e organização do processo em geral, então o aspecto técnico tende a ser esquecido e sobreleva a questão de princípio. ${ }^{152}$

A afirmação do binômio oralidade-escrita no plano da técnica processual oferece a vantagem de explicitar que a oralidade não constitui um valor em si. É da conjugação entre elementos escritos e orais que o legislador e o juiz estruturam um procedimento eficiente, levando em consideração as limitações de tempo e recursos materiais de cada localidade.

Ora, deslocar o tema da oralidade e da escrita do plano principiológico para o patamar da técnica processual também traz a vantagem de explicitar que a dosagem adequada de elementos escritos e orais no procedimento visando à obtenção de resultados eficientes não pode ser abordada como questões estanques no tempo e no espaço.

A questão da forma oral ou escrita de realização dos atos processuais não pode ser estudada exclusivamente numa perspectiva de confiabilidade da instrução, mas também deve ser analisada sob uma ótica de gerenciamento de processos e otimização do tempo dos operadores do Direito.

151 DINAMARCO, Cândido Rangel. Instituições de Direito Processual Civil, v. 1, p. 197.

152 OLIVEIRA, Carlos Alberto Alvaro de. Do formalismo no processo civil: proposta de um formalismovalorativo. 3. ed. São Paulo: Saraiva, 2009. p. 147. A meio caminho desse racicínio está a conclusão de NICORA ATTILIO em relação ao processo civil italiano e ao canônico: Il problema dell'oralità non è né una mera questione teoretica, né una pura questione di organizzazione giudiziaria: è l'una e l'altra cosa insieme, è una idea incarnata, è un principio-guida che nasce dall'esperienza e all'a esperienza vuol ritornare, e perciò edve accetare tutta la concretezza e la fatica di questa sua necessaria «storicizzazione». ATTILIO, Nicora. Il principio di oralità nel diritto processuale civile italiano e nel diritto processuale civile canonico. Series Facultatis Iuris Canonici. Roma: Università Gregoriana, 1977. p. 613. 
Demais disso, discussões acerca da concentração ou fracionamento das atividades em audiência, bem como sobre a admissão de memoriais escritos em substituição aos debates orais, e até mesmo a admissão de affidavits em substituição à prova testemunhal resvalam necessariamente em opções técnicas que o magistrado deve realizar - dentro de uma margem de discricionariedade que a lei lhe confere - levando em consideração as particularidades de cada comarca.

Ora, seria uma ingenuidade supor que discussões sobre temas sensíveis tais como estruturação das audiências, prova testemunhal, sustentação oral, entre outros, não estivessem estreitamente relacionadas com a necessidade do Poder Judiciário em dar vazão a um número crescente de processos e ao interesse de advogados e partes em ter as suas demandas apreciadas com qualidade e celeridade.

A afirmação da oralidade como um princípio poderia levar à falsa suposição de que o tema poderia ser discutido em termos abstratos, ou que possuísse um valor universalmente aceito. 


\section{ORALIDADE E DEVIDO PROCESSO LEGAL NUMA PERSPECTIVA COMPARATIVA}

Uma decorrência da afirmação da oralidade enquanto princípio é a afirmação da oralidade como uma garantia processual das partes.

MARCEL STORME, para justificar a prevalência da oralidade sobre a escrita, destaca a palavra hearing da dicção do artigo $6^{\circ}$, $§ 1^{\circ}$, da Convenção Europeia para a Salvaguarda dos Direitos do Homem e das Liberdades Fundamentais (everyone is entitled to a fair and public hearing). ${ }^{153} \mathrm{Na}$ mesma linha, DIETER LEIPOLD afirma que, em face do citado dispositivo, uma lei que determinasse um procedimento inteiramente escrito, excluindo todos os elementos de oralidade do procedimento, seria de validade duvidosa. Na visão do autor, apenas seria legítimo um procedimento inteiramente escrito quando as partes acordassem em não realizar audiência alguma, pois havendo interesse de alguma delas na audiência, esta deveria ser obrigatoriamente realizada. ${ }^{154}$

Todavia, ocorre que a Convenção não garante às partes o direito de expor suas razões oralmente perante o juiz, para que este as ouça, mas sim o direito de ter a demanda examinada pelo juiz, sendo que este exame pode se realizar pela leitura de uma petição ou em audiência.

Tanto é assim que a pretendida alusão ao sentido da audição na redação do artigo $6^{\circ}, \S 1^{\circ}$, da Convenção Europeia, somente seria possível diante das versões em língua inglesa, alemã, espanhola e francesa do referido diploma. Nestas versões, em sentido literal, todos teriam o direito de ser ouvido pelo juiz (Everyone is entitled to a fair and public hearing; Jedermann hat Anspruch darauf, dass seine Sache in

\footnotetext{
153 STORME, Marcel. More voice, less print - Why Court proceedings should become more oral. In: CARPI, Federico; ORTELLS, Manuel (Org.). Oralidad y Escritura en un Proceso Civil Eficiente (Oral and Written Proceedings: Efficiency in Civil Procedure). v. I - Ponencias generales e informes nacionales (General reports and national reports). València: International Association of Procedural Law (IAPL), Universitat de València, 2008. p. 43.

${ }^{154}$ LEIPOLD, Dieter. Oral and Written Elements within the Introductory Phase of Civil Proceedings, p. 71. A rigor, trata-se de uma assertiva bastante difundia. PÉREZ-RAGONE e PALOMO VELÉZ também aduzem que a oralidade teria respaldo no artigo $6, \S 1^{\circ}$, da Convenção Europeia para a Salvaguarda dos Direitos do Homem e das Liberdades Fundamentais. PÉREZ-RAGONE, Álvaro; PALOMO VÉLEZ, Diego. Oralidad y prueba, p. 368. Na mesma linha está STÜRNER-MURRAY, afirmando que algum grau de oralidade seria garantido pelo citado dispositivo. MURRAY, Peter; STÜRNER, Rolf. German Civil Justice. Durham: Carolina Academic, 2004. p. 185, nota 153.
} 
billiger Weise öffentlich und innerhalb einer angemessenen Frist gehört wird; Toda persona tiene derecho a que su causa sea oída; Toute personne a droit à ce que sa cause soit entendue). Todavia, nas versões portuguesa e italiana a pretendida referência não existe, garantindo-se apenas o direito de ter a demanda analisada (Qualquer pessoa tem direito a que a sua causa seja examinada; Ogni persona ha diritto a che la sua causa sia esaminata). ${ }^{155}$

Nestes termos, não se pode extrair da redação do artigo $6^{\circ}, \S 1^{\circ}$, da Convenção Europeia qualquer alusão à oralidade, tal como pretendem MARCEL STORME e DIETER LEIPOLD.

Deveras, como afirma FRITZ BAUR, as derrogações à oralidade no processo civil não significam violações ao artigo 6.1 da Convenção Europeia. ${ }^{156}$ Em nenhum momento a Convenção Europeia para a Salvaguarda dos Direitos do Homem e das Liberdades Fundamentais garante aos litigantes um processo oral. O que se afirma no referido artigo é a garantia da inafastabilidade da jurisdição.

É verdade que alguns países elevaram a oralidade ao patamar constitucional. Mesmo assim, fala-se apenas em predominância da oralidade sobre a escrita, e nunca na obrigatoriedade de audiência em todos os procedimentos.

O artigo 120.2 da Constituição da Espanha determina que El procedimiento será predominantemente oral, sobre todo en materia criminal. Na Áustria, o artigo 90 da Bundes-verfassungsgesetz, de 1929, dispõe que o procedimento nas causas civis e criminais serão orais e públicos, podendo a lei estabelecer exceções. ${ }^{157}$ Deveras, a própria oralidade na Zivilprozessordnung de 1895 pode ser considerada uma resposta ao comando constitucional previsto na Staatsgrundgesetz über die allgemeinen Rechte der

${ }^{155}$ A União Europeia possui 23 idiomas oficiais. Mas o confronto das versões alemã, francesa, espanhola, italiana e portuguesa do artigo $6^{\circ}$ Convenção Europeia para a Salvaguarda dos Direitos do Homem e das Liberdades Fundamentais já é suficiente para afirmar que não se pode extrair desse dispositivo nenhuma alusão à oralidade no processo civil.

156 BAUR, Fritz. Les Garanties Fondamentales des Parties dans le Procés Civil em République Fédérale d'Allemagne. In: CAPPELLETTI, Mauro ; TALLON, Denis (Ed.). Fundamental Guarantees of the Parties in Civil Litigation. Milano; New York: Giuffrè; Oceana, 1971. p. 22.

${ }^{157}$ Artikel 90. (1) Die Verhandlungen in Zivil- und Strafrechtssachen vor dem erkennenden Gericht sind mündlich und öffentlich. Ausnahmen bestimmt das Gesetz. Em tradução oficial para o inglês, disponível no site do Bundeskanzleramt, (www.bka.gv.at): art. 90. (1) Hearings in civil and criminal cases are oral and public. Exceptions are regulated by law. 
Staatsbürger de 21 de dezembro de 1867 (Dezemberverfassung), que já elevava a oralidade a um patamar constitucional. ${ }^{158}$

Na China, o artigo 12 da Lei Processual Civil estabelece um dispositivo muito interessante, no sentido de que todas as pessoas teriam o direito de autodefesa em matéria civil, ou seja, o direito de estar presente em juízo e de se manifestar com suas próprias palavras antes do julgamento, o que, em tese, estabeleceria a oralidade como um valor fundamental. Todavia, como observa HONGLIANG WANG, não é o que se observa na prática, e a doutrina e o legislador não dão especial atenção à oralidade neste aspecto. $^{159}$

No Brasil, o artigo 98, inciso I, da Constituição da República menciona expressamente a oralidade no procedimento dos Juizados Especiais. No entanto, a oralidade não é estabelecida de forma absoluta pela legislação infraconstitucional; em verdade, na Lei n. 9.099/95 serve para fomentar a conciliação entre as partes, e foi estabelecida como uma garantia para maior qualidade da instrução.

Assim, pode-se afirmar que a oralidade não constitui uma garantia fundamental dos litigantes no processo civil, uma vez que pode validamente ser afastada pelo legislador ou pelo juiz em determinados procedimentos. Ao contrário do que ocorre no âmbito do processo penal, não se aplica ao processo civil a chamada cláusula de confronto - right to confrontation -, conforme explorado em tópico próprio.

\footnotetext{
${ }^{158}$ A referência à oralidade no procedimento encontra-se publicada na Reichsgesetzblatt 144, art. 10, de 21 de dezembro de 1867. Disponível no site da Österreichische Nationale Bibliothek: <http://alex.onb.ac.at/cgicontent/anno-plus?apm=0\&aid=rgb\&datum $=18670004 \&$ seite $=00000399 \&$ zoom=2>. Acesso em: 29 jul. 2009. Trata-se do mesmo dispositivo posteriormente reproduzido no artigo 90 da Bundes-verfassungsgesetz de 1929.

${ }^{159}$ WANG, Hongliang. Civil pre-trial procedure in China. In: CARPI, Federico; ORTELLS, Manuel (Org.). Oralidad y Escritura en un Proceso Civil Eficiente, v. I, p. 301.
} 


\section{ORALIDADE E COOPERAÇÃO NO PROCESSO}

A oralidade permite uma maior cooperação entre juiz, partes e advogados. Isso porque a audiência é o palco natural para o diálogo entre os envolvidos, proporcionando-lhes a discussão aberta sobre as peculiaridades do caso.

Tradicionalmente a doutrina alemã entendia que o momento processual adequado para se operar o dever de cooperação do juiz (Hinweisepflicht) deveria ser a audiência preliminar. Todavia, com a redação do §139 (4) da ZPO determinada pela reforma de 2001, que dispõe que o Hinweiseplficht deve ser exercido pelo juiz o quanto antes, combinado com o §128 (4), passou-se a entender que o juiz deveria exercer o dever de colaboração por escrito já na fase de introdução da demanda. ${ }^{160}$

No tocante a esse aspecto, acredita-se que a audiência de instrução é a ocasião mais propícia para a colaboração entre as partes, conforme exposto em tópico abaixo.

${ }^{160}$ LEIPOLD, Dieter. Oral and Written Elements within the Introductory Phase of Civil Proceedings, p. 75. MURRAY, Peter; STÜRNER, Rolf. German Civil Justice, p. 171. 


\section{ORALIDADE NA FASE PRELIMINAR}

A regular estruturação e a racionalização da fase preliminar ao processo (pre-action) e da fase preliminar ao julgamento (pre-trial) são pressupostos para a boa administração da justiça.

Embora a fase preliminar ao processo seja carecedora de uma regulamentação em boa parte dos países - no Brasil inclusive -, a fase preliminar ao julgamento de primeira instância é um dos pontos de maior grandeza na discussão acerca da melhoria de qualidade dos serviços judiciais.

A existência de uma fase preliminar ou preparatória (pre-trial) bem delimitada e distinta da fase principal (trial) é muito fácil de ser identificada nos sistemas de Common Law, e isso se deve, em grande medida, ao uso do júri em matéria civil. A inviabilidade prática de se convocarem os jurados para uma séria de audiências preparatórias consolidou a ideia de que a fase em plenário deveria se limitar às atividades instrutórias e de julgamento. ${ }^{161}$ Todavia, mesmo com o declínio do uso do júri em matéria civil, este modo de organização do trabalho no processo ainda se mostra útil para fins de economia e de racionalização das atividades do juiz e das partes.

Não obstante, o julgamento por júri e a concentração procedimental, especificamente quanto aos reflexos no âmbito das provas, podem e devem ser analisados de formas distintas. DAMAŠKA afirma que estas duas características do procedimento de Common Law, apesar de serem vistas, como Castor e Pollux pelos olhos de um historiador, não justificam a adoção das mesmas regras sobre provas. ${ }^{162}$

Deveras, assevera DAMAŠKA que, ao contrário do que se afirma de modo corrente, não é o uso do júri que explicaria a existência de um complexo regramento em matéria probatória nos sistemas de Common Law. O júri, por si só, não exige regras técnicas sobre provas. A separação do processo em duas fases nitidamente distintas, e a consequente fissão do julgamento entre dois órgãos (o júri e o juiz profissional) é que abriria espaço para o desenvolvimento de regras de exclusão de provas. ${ }^{163}$

161 JOLOWICZ, John Antony. On Civil Procedure. Cambridge: Cambridge University, 2000. p. 374.

162 DAMAŠKA, Mirjan. Evidence Law Adrift. New Haven-London, Yale University, 1997. p. 3.

163 DAMAŠKA, Mirjan. Evidence Law Adrift, p. 26. 
Uma das experiências de boa administração da justiça mais paradigmáticas do século XX na Europa Continental, o Modelo de Stuttgart, teve como um de seus pilares fundamentais a otimização das atividades judiciais na fase preliminar, seja por dar primazia à colaboração entre partes, advogados e juiz (Hinweisepflicht), proporcionando uma decisão qualitativamente melhor, seja por desonerar o juiz de atividades tidas como não essenciais, proporcionando-lhe o tempo necessário para desenvolver um papel mais ativo nos processos.

No Brasil, a tese segundo a qual o juiz deve exercer um papel mais ativo no processo ganhou força principalmente a partir da década de 1990, estando hoje razoavelmente assentada. O princípio da colaboração ou cooperação no processo civil vem igualmente ganhando espaço, tanto no meio acadêmico, como no meio forense. Todavia, a questão da racionalização das atividades judiciais, de modo a proporcionar ao juiz o tempo necessário para desenvolver o papel que dele vem sendo exigido, é algo que pouco é discutido.

\subsection{ORALIDADE NA FASE POSTULATÓRIA}

A fase postulatória não admite muitos elementos de oralidade na generalidade dos sistemas, e é natural que assim o seja, pois a forma escrita, por ser mais precisa, é a mais adequada para esta fase do procedimento.

TARUFFO afirma que a forma escrita pode não ser o modo mais eficiente para as alegações iniciais das partes em termos de tempo e dinheiro, mas certamente o é em termos de precisão, detalhamento e completude das alegações, pois $a$ proceeding in which the first pleadings were base just upon the memory of what the parties said is doomed to be uncertain and dangerous, that is: inefficient. ${ }^{164}$

Na mesma linha, DIETER LEIPOLD afirma que a necessidade de uma petição inicial escrita não contradiz a oralidade. ${ }^{165}$ Deveras, é interessante notar que na Espanha mesmo o juicio verbal se inicia por escrito (LEC, art. 437.1).

${ }^{164}$ TARUFFO, Michele. Orality and writing as factors of efficiency in civil litigation, p. 189.

165 LEIPOLD, Dieter. Oral and Written Elements within the Introductory Phase of Civil Proceedings, p. 58. 
O modelo de Stuttgart, desenvolvido a partir de 1967 com base num estudo publicado por FRITZ BAUR em 1966 (Wege zu einer Konzentration in der Mündlichen Verhandlung im Zivilprozeß, recolhido na coletânea Beiträge zur Gerichtverfassung und zum Zivilprozeßrecht, Tübingen, J.C.B. Mohr, 1983), optava pelo modelo escrito na fase preliminar. ROLF BENDER, então juiz presidente do Oberlandesgericht de Stuttgart, assevera que o modelo de Stuttgart combina técnica oral com técnica escrita, de modo a buscar a maximização de resultados, porquanto tanto o princípio da oralidade como o princípio da escritura falharam em demonstrar sua validade em termos absolutos. ${ }^{166}$

Segundo BENDER, a técnica escrita é particularmente vantajosa para a introdução da demanda, porquanto a preocupação principal neste momento não é a rápida troca de informações entre as partes, mas sim a delimitação dos limites da disputa por meio de uma técnica que não vincule o desenvolvimento do trabalho a uma determinada data e local. ${ }^{167}$

Vale enfatizar que até mesmo FRANZ KLEIN já reconhecia a conveniência na adoção da escritura com maior largueza em detrimento da oralidade na fase de introdução da demanda. O que traz bons frutos, afirmava o autor, é a oralidade da palavra livre, não a oralidade artificial da leitura. ${ }^{168}$

Ora, a racionalização das atividades do juiz é um leitmotiv no pensamento de KLEIN. A introdução da demanda e a contestação em audiência - e não por escrito - significa desperdiçar tempo precioso do juiz, porquanto tais atos poderiam, sem prejuízo significativo, ser realizados de modo mais econômico.

Demais disso, o Modelo de Stuttgart não valoriza o controle do juiz sobre a petição inicial. Conforme afirma BENDER, pode o juiz permanecer inativo durante a primeira fase de introdução da demanda, porquanto caberia aos cartorários o mero controle sobre a regularidade formal dos primeiros atos e manifestações das partes (petição inicial, citação, contestação e réplica), de modo que o juiz somente começaria a

\footnotetext{
166 BENDER, Rolf. The Stuttgart Model. In: CAPPELLETTI, Mauro; WEISNER John (Ed.). Access to Justice. v. II. Book II. Milano: Giuffrè, 1979. p. 437-438.

167 BENDER, Rolf. The Stuttgart Model, p. 438.

${ }^{168}$ Die eindrucksvolle, fruchtbare Mündlichkeit ist die Mündlichkeit des frei gesprochenen Wortes, der ungezwungenen, natürlich Rede, nicht die Mundlichkeit des Verlesens. Em tradução livre: "A oralidade mais interessante e frutífera é aquela do livre discurso, da fala natural e sem restrições, e não aquela da simples leitura de algo previamente preparado”. KLEIN, Franz. Vorlesungen über die Praxis des Civilprocess. Wien: Manz, 1900. p. 123-124.
} 
desenvolver suas atividades, em média, seis semanas após o ajuizamento da demanda, ou seja, após duas manifestações escritas do autor e uma do réu. ${ }^{169}$

A experiência prática teria demonstrado que quase nenhum juiz se dispunha a analisar atentamente todas as petições iniciais diante de pautas lotadas, de modo que o ideal de um juiz ativo na fase inicial, propondo emendas à petição inicial ou outras medidas tendentes a acelerar a marcha do processo, era irrealizável em concreto. Assim, como a atividade do juiz nesta primeira etapa do procedimento na prática se reduzia ao mero controle de regularidade formal das manifestações das partes, o modelo de Stuttgart recomendou a delegação de tais atividades aos servidores. ${ }^{170}$

Ora, o modo de controle da petição inicial é algo muito discutido no seio da magistratura. É claro que algum controle de regularidade formal pode ser realizado por uma triagem feita pelos próprios servidores, notadamente em relação aos documentos que devem acompanhar a petição inicial, considerando-se as demandas mais recorrentes. Diante do enorme volume de serviço que atinge grande parte dos órgãos jurisdicionais no Brasil, a delegação de atividades burocráticas aos servidores é inevitável.

O controle da petição inicial, da perspectiva do juiz, evoca uma série de particularidades práticas, que muitas vezes escapam até mesmo da pauta das escolas judiciais mais rigorosas. O juiz mais experiente é capaz de perceber um padrão nos equívocos e falhas mais comuns na redação da petição inicial, de acordo com a espécie de demanda. Além disso, em comarcas pequenas, é possível ao juiz perceber até mesmo a repetição dos mesmos erros em relação a um mesmo profissional.

Em grossas linhas, o controle de petição inicial nada mais é do que um filtro realizado pelo juiz acerca da viabilidade de uma demanda. Cabe a cada juiz, de acordo com a natureza de cada demanda, estabelecer a gramatura deste filtro, de modo que o controle da petição inicial pode ser mais ou menos rigoroso, de acordo com as consequências procedimentais da percepção tardia de uma petição inicial mal redigida.

Por exemplo, em se tratando de uma demanda envolvendo alimentos, o baixo rigor no controle da petição inicial não importa maiores tumultos, porquanto esclarecimentos adicionais podem ser prestados após a frustração da tentativa de conciliação em audiência. Já em demandas envolvendo responsabilidade civil por ato

169 BENDER, Rolf. The Stuttgart Model, p. 438-439.

170 BENDER, Rolf. The Stuttgart Model, p. 440-441. 
ilícito, o controle da petição deve ser mais rigoroso, porquanto a clareza na narrativa do suposto ato ilícito induz maior clareza na contestação, e por consequência, traz benefícios para a fase de instrução.

A vantagem da introdução da demanda de forma escrita é sem dúvida a sua maior certeza, tanto que é esta a prática mais corriqueira e aceita numa perspectiva comparativa.

Todavia, a introdução da demanda de forma oral nos Juizados Especiais Cíveis tem demonstrado que essa prática é possível e operável. Nesta situação, na qual a própria parte interessada preenche um formulário no cartório do Juizado para dar início a uma demanda, a maior dificuldade é a compreensão da causa de pedir, e não propriamente do pedido.

No entanto, a propositura oral da demanda apresenta uma vantagem em termos de acesso à justiça, conforme será afirmado abaixo.

\subsection{INTRODUÇÃO DA DEMANDA DE FORMA ORAL OU POR FORMULÁRIOS COMO MEIO DE PERMITIR O ACESSO À JUSTIÇA}

A ZPO alemã previa a possibilidade de introdução oral da demanda perante a Amtsgerichte até 1976, quando tal possibilidade foi suprimida, por ter caído em desuso. ${ }^{171}$

Na China, como a representação por advogado não é obrigatória, a introdução da demanda de forma oral desempenha um papel importante na universalização da tutela jurisdicional. A Lei de Processo Civil de 1991 da República da China, em seu artigo 109, admite que, no processo ordinário, caso o autor tenha genuína dificuldade em apresentar uma petição inicial escrita, a demanda seja proposta oralmente, hipótese em que o cartório transcreverá o pedido por escrito, para que seja notificada a parte contrária. No processo sumário, o artigo 143 do referido diploma permite que em casos simples - ou seja, de pouca complexidade - a demanda possa ser proposta oralmente.

${ }^{171}$ LEIPOLD, Dieter. Oral and Written Elements within the Introductory Phase of Civil Proceedings, p. 60. 
Segundo HONGLIANG WANG, os citados dispositivos desempenham um papel importante na justiça civil chinesa, e são frequentemente aplicados na prática, notadamente em áreas rurais. Demais disso, o autor enfatiza o dever do juiz em escutar as partes fora do ambiente do fórum, para permitir um acesso facilitado aos camponeses. ${ }^{172}$

No Japão, onde a representação por advogados não é obrigatória e o número destes profissionais é muito reduzido, admite-se o ajuizamento da demanda na forma oral no procedimento sumário e não se realiza uma fase preliminar escrita. ${ }^{173} \mathrm{Na}$ Grécia, conforme relata DIMITRIS MANIOTIS, o ajuizamento da demanda e a contestação de forma oral são regras do procedimento perante os Juizados de Paz. ${ }^{174}$

Na Espanha, caso a demanda não exceda 900 euros, admite-se que a petição inicial consista num formulário padronizado fornecido pelo próprio tribunal (LEC, art. 437.2). De igual modo, a European Small Claims Procedure também admite a petição inicial no formato de formulário.

Em todos estes casos, o que se observa é ou o preenchimento de formulários ou a redução a termo da demanda pelo cartório judicial, conforme exposto oralmente pela pessoa interessada.

É claro que o ideal seria franquear em todos os casos a assistência às partes por meio de um advogado ou defensor público. No entanto, permitir a demanda realizada de forma oral promove a universalização no acesso à justiça. Conforme afirma DIETER LEIPOLD, a obrigatoriedade de uma petição inicial escrita pode significar um obstáculo ao acesso à justiça. ${ }^{175}$

O critério de valor da causa, no entanto, não parece muito adequado. Isso porque não é o valor envolvido na demanda que irá determinar sua maior ou menor complexidade, mas sim a espécie de demanda envolvida. Conforme afirmou-se acima, a maior dificuldade no julgamento de demandas introduzidas de forma oral é a correta compreensão da causa de pedir. Assim, nos casos em que a causa de pedir é praticamente autoevidente em razão da própria narrativa dos fatos, a introdução oral da

\footnotetext{
172 WANG, Hongliang. Civil pre-trial procedure in China, p. 296.

173 HONMA, Manabu. The Preliminary Phase and the Trial Agreement in Japan. In: CARPI, Federico; ORTELLS, Manuel (Org.). Oralidad y Escritura en un Proceso Civil Eficiente, v. I, p. 254.

${ }^{174}$ MANIOTIS, Dimitris. Some Remarks concerning the Pre-Trial Stadium and the Proceeding before the Court according to the Greek Code of Civil Procedure. In: CARPI, Federico; ORTELLS, Manuel (Org.). Oralidad y Escritura en un Proceso Civil Eficiente, v. I, p. 269-270.

${ }^{175}$ LEIPOLD, Dieter. Oral and Written Elements within the Introductory Phase of Civil Proceedings, p. 60.
} 
demanda não oferece maiores prejuízos no que se refere à clareza. É o que ocorre na generalidade das demandas envolvendo relações de consumo e acidentes de trânsito.

Outro ponto levantado pela introdução da demanda de forma oral na prática dos Juizados Especiais Cíveis é a relativização do princípio dispositivo. Isso porque muitas vezes jurisdicionados desacompanhados de advogado formulam pedidos juridicamente impossíveis, ou os formulam em face da pessoa equivocada. Por exemplo, se um indivíduo desacompanhado de advogado formula oralmente no Juizado Especial Cível um pedido em face de uma pessoa que manifestamente é parte ilegítima, mas da própria narrativa dos fatos o equívoco cometido pelo cidadão é evidente (e.g. danos morais pleiteados em face do SERASA, em vez de constar do polo passivo a empresa que realizou a cobrança indevida), a citação da empresa correta não importa em violação de garantias processuais, havendo oportunidade para a parte autora retificar sua manifestação inicial por ocasião da audiência de conciliação.

Em outras palavras, tratando-se de demanda iniciada por declaração oral do autor no âmbito do Juizado Especial Cível, é lícito ao juiz interpretar com maior largueza certas regras processuais, desde que não haja prejuízo à parte adversa.

Demais disso, a introdução da demanda de forma oral exige que seja dado ao servidor responsável pelo Juizado Especial algum treinamento para que este possa esclarecer os jurisdicionados sobre o procedimento a ser adotado com suficiente proficiência.

\subsection{A DESIGNAÇÃO DA AUDIÊNCIA PRELIMINAR COMO UMA QUESTÃO DE CONVENIÊNCIA: EM DEFESA DO REGIME FACULTATIVO DA AUDIÊNCIA PRELIMINAR}

A escolha entre um procedimento preliminar escrito ou oral não é algo que pode ser discutido em abstrato, sem considerar as peculiaridades de cada região, o nível de movimentação forense, recursos humanos e materiais à disposição do juízo, natureza preponderante das causas, entre outros elementos.

Tanto é assim que o Código de Processo Civil Tipo para a América Latina, fonte inspiradora do artigo 331 do CPC brasileiro, silencia propositalmente acerca do regime obrigatório ou facultativo da audiência preliminar. Os 
seus elaboradores, cônscios da polêmica sobre este ponto, deixaram para que cada ordenamento resolvesse a questão da forma mais condizente com suas próprias tradições jurídicas. $^{176}$

Neste esteio, BARBOSA MOREIRA afirma que a análise da obrigatoriedade ou facultatividade da audiência do artigo 331 do CPC não poder ser realizada apenas no plano dogmático. Conforme afirma o autor, o confronto entre o regime obrigatório e o regime facultativo da audiência não é questão que possa ser discutida em plano puramente teórico. Não envolve grandes princípios filosóficos ou éticos; nem sequer grandes princípios jurídicos. Trata-se de saber qual dos dois regimes funciona melhor na prática. O teste decisivo é o da experiência. ${ }^{177}$

Na mesma linha, CARLOS ALBERTO ALVARO DE OLIVEIRA afirma que a oralidade, por ter servido como programa de reforma na passagem do processo comum para o processo moderno, é ainda vista como uma verdadeira questão de princípio, e não como uma simples técnica. Assim, a oralidade é posta pela doutrina em geral apenas no contexto dos princípios processuais, passa a ser vista como um elemento norteador da estruturação e da organização do processo em geral, sem se dar atençno processoão ao seu caráter técnico, ou seja, sem cuidar para o fato de que se trata de um meio para a obtenção de determinados fins. ${ }^{178}$

Conforme sustenta o citado autor, essa visão distorcida da oralidade exagerada, que repele por completo a técnica do processo escrito, dá ensejo ao formalismo da oralidade, que se afasta das exigências originárias do princípio. ${ }^{179}$

GERHARD WALTER, partindo de premissas diversas, mas chegando às mesmas conclusões, afirma que a oralidade no procedimento representa uma garantia para um julgamento mais correto, e que como tal, não pode ser afastada com base em critérios de conveniência. Para chegar a esta conclusão, o autor parte da premissa de que o

\footnotetext{
${ }^{176}$ DINAMARCO, Cândido Rangel. A Reforma do Código de Processo Civil. 2. ed. São Paulo: Malheiros, 1995. p. 124.

177 BARBOSA MOREIRA, José Carlos. Vicissitudes da audiência preliminar. Temas de Direito Processual (Nona Série). São Paulo: Saraiva, 2007. p. 140.

178 OLIVEIRA, Carlos Alberto Alvaro de. Do formalismo no processo civil, p. 147. A meio caminho deste raciocínio está a conclusão de NICORA ATTILIO em relação ao processo civil italiano e ao canônico: Il problema dell'oralità non è né una mera questione teoretica, né una pura questione di organizzazione giudiziaria: è l'una e l'altra cosa insieme, è una idea incarnata, è un principio-guida che nasce dall'esperienza e all'a esperienza vuol ritornare, e perciò edve accetare tutta la concretezza e la fatica di questa sua necessaria «storicizzazione». ATTILIO, Nicora. Il principio di oralità nel diritto processuale civile italiano e nel diritto processuale civile canonico. Series Facultatis Iuris Canonici. Roma: Università Gregoriana, 1977. p. 613.

179 OLIVEIRA, Carlos Alberto Alvaro de. Do formalismo no processo civil, p. 148.
} 
princípio da oralidade representa uma maior garantia para a busca da verdade, e assim conclui que exceções à oralidade sem lastro em razões objetivas e concretas que recomendem seu afastamento implicariam restrições indevidas ao direito à prova ${ }^{180}$.

Contudo, GERHARD WALTER considera legítimas as limitações à oralidade estabelecidas pela Vereinfachungsnouvelle de 1976, que, alterando o §272 da ZPO, permitiu ao juiz optar pela realização de uma audiência preliminar - früher erste Termin - ou adotar um procedimento inteiramente escrito até a audiência principal (Haupttermin), levando em consideração elementos como a ausência de controvérsia sobre a matéria fática, autocomposição do litígio, contumácia de alguma das partes, entre outras razões $^{181}$. Diante disso, pode-se afirmar que a früher erste Termin prevista no $§ 272$ da ZPO pode ser dispensada pelo juiz quando presentes situações fáticas que indiquem que sua realização implicaria tão somente custo para as partes, sem maiores benefícios.

Ora, em essência, tal posição não é diversa daquela adotada por BARBOSA MOREIRA ao afirmar que a decisão pela qual o juiz dispensa a realização da audiência preliminar, saneando o processo por escrito, deve ser motivada, com a exposição das razões pelas quais não convocou a referida audiência. ${ }^{182}$ Em ambos os casos, verificase a não realização da audiência, a critério do juiz, desde que por decisão motivada, na qual fique demonstrada que a sua realização teria pequena probabilidade de surtir resultados úteis.

Demais disso, importa notar que o regime obrigatório da audiência preliminar não pode ser sustentado com base no princípio da oralidade, tal como definido tradicionalmente pela doutrina. Segundo CAPPELLETTI, a oralidade possui um significado primário, relacionado à livre apreciação da prova testemunhal e das declarações das partes, e um sentido secundário, que diz respeito à possibilidade de o juiz exigir das partes esclarecimento oral sobre os fatos declarados como fundamentos de suas pretensões. ${ }^{183}$

\footnotetext{
${ }^{180}$ Grundsätzlich nur eine mündliches Verfahren die Garantie einer richtigen Entscheidung beitet und daß für eine Ausnahme von diesem Grundsatz nicht lediglich Zweckmäßigkeitserwägungen genügen dürfen, vielmehr ein über solche Erwägungen hinausgehender sachlicher Grund. Em tradução livre: "Fundamentalmente, apenas um procedimento marcado pela oralidade é capaz de garantir uma decisão mais justa e acertada; por conta disto, exceções a ela não podem ser justificadas simplesmente por meio de considerações de conveniência, devendo, pelo contrário, serem fundadas em razões objetivas importantes o bastante para afastarem este princípio em um caso concreto”. WALTER, Gerhard. Freie Beweiswürdigung. Tübingen: J.C.B. Mohr (Paul Siebeck), 1979. p. 332. Essa obra também está disponível em castelhano: WALTER, Gerhard. Libre Apreciación de La Prueba, Investigación acerca del significado, las condiciones y límites del libre convencimiento judicial, 1985.

${ }^{181}$ WALTER, Gerhard. Freie Beweiswürdigung, p. 332.

182 BARBOSA MOREIRA, José Carlos. Vicissitudes da audiência preliminar, p. 136.

183 CAPPELLETTI, Mauro. La testimonianza della parte nel sistema dell'oralità, Parte Prima, p. 69 e 212.
} 
Ora, o sentido primário é abraçado pelo direito brasileiro ao adotar o sistema da livre apreciação das provas (art. 332, CPC), ao passo que o sentido secundário encontra guarida no artigo 342 do CPC, que trata do depoimento pessoal. Note-se que a audiência do artigo 331 do CPC não tem como escopo a realização de atividades instrutórias. A única atividade relacionada às provas realizada nesta audiência é a organização da atividade instrutória, que poderia, sem prejuízo, ser realizada por escrito.

Em sentido contrário, DINAMARCO sustenta que no processo civil brasileiro, em que o saneamento é ato essencial e indispensável, omitir a audiência preliminar significaria omitir um ato indispensável do procedimento. Inexistem na ordem jurídica brasileira, as razões de ordem sistemática, ou mesmo históricas, que no plano geral da América Latina desaconselham a obrigatoriedade plena. ${ }^{184}$

Todavia, há de se considerar que a não realização da audiência preliminar significa apenas a adoção da técnica escrita de saneamento, e não a exclusão por completo da atividade saneadora. Em segundo lugar, não se pode olvidar que a opção do legislador brasileiro de 1973, conforme afirma BARBOSA MOREIRA, foi manter a técnica escrita de saneamento do processo, no esteio do Código de 1939, ou seja, a tradição histórica no Brasil é a opção pelo saneamento realizado de forma difusa e escrita. ${ }^{185}$

Em relação à organização da atividade instrutória e outras providências de governança judicial, a designação de uma audiência especialmente para tal fim faz muito sentido nos sistemas de Common Law, nos quais as partes têm poderes relativamente amplos para requisitar documentos e informações da parte adversária (é o caso da discovery norte-americana e da disclosure inglesa). Mas no mundo da Civil Law, a designação de uma case management conference não tem muita razão de ser. DIETER LEIPOLD afirma que a designação de tal ato, ao menos na Alemanha, seria desnecessária e serviria apenas para causar atrasos indevidos. ${ }^{186}$

Quanto ao escopo conciliatório, há de se reconhecer que este por si só não justificaria a previsão legal expressa de uma audiência exclusivamente para este fim. Rigorosamente, a previsão de uma audiência com propósito exclusivamente conciliatório seria inútil, pois a combinação do artigo 125, inciso IV (dever do juiz em

\footnotetext{
184 DINAMARCO, Cândido Rangel. A Reforma do Código de Processo Civil. 2. ed. São Paulo: Malheiros, 1995. p. 124.

185 BARBOSA MOREIRA, José Carlos. Saneamento do Processo e Audiência Preliminar. Temas de Direito Processual (Quarta Série). São Paulo: Saraiva, 1989. p. 131.

${ }^{186}$ LEIPOLD, Dieter. Oral and Written Elements within the Introductory Phase of Civil Proceedings, p. 68.
} 
promover a conciliação) com o artigo 342 (poder do juiz de determinar o comparecimento pessoal das partes), ambos do CPC, já autorizaria ao juiz a convocar as partes para tentar a conciliação. ${ }^{187}$

Quanto às razões de ordem sistemática, deve-se atentar para a observação, feita por CARLOS ALBERTO ALVARO DE OLIVEIRA, no sentido de que a oralidade não deve ser compreendida apenas no plano dos princípios processuais, mas sim como uma técnica voltada para melhorar ou facilitar o alcance de determinados fins. ${ }^{188}$ Nesta mesma linha, é preciso notar que a oralidade não mais carrega a carga ideológica que possuía no passado, no contexto da superação do processo escrito do ius commune, representando hoje uma entre duas alternativas de comunicação no processo. ${ }^{189}$

Ainda, vale lembrar a lição de CHIOvEndA no sentido de que um processo no qual a audiência tem grande importância só poderá dar bons frutos caso o juiz vá à audiência com a exata noção do que está sendo tratado nos autos. ${ }^{190}$ Ou seja, de nada adiantaria tornar obrigatória a audiência de conciliação se os juízes não tiverem tempo para se preparar para este ato, seja por razões de mentalidade ou por excesso de trabalho, pois nestas hipóteses dificilmente a audiência traria bons resultados.

Nesta linha, GAJARDONI afirma que o juiz é quem tem melhores condições de avaliar, diante das circunstâncias de cada caso concreto, se a audiência preliminar pode ser proveitosa ou não. ${ }^{191}$

Tais considerações corroboram a assertiva de BARBOSA MOREIRA no sentido de que a escolha entre o regime obrigatório ou facultativo da audiência preliminar não envolve grandes princípios, mas se trata apenas de saber qual dos regimes funciona melhor na prática. ${ }^{192}$

\footnotetext{
${ }^{187}$ Neste sentido, GAJARDONI, Fernando da Fonseca. Técnicas de aceleração do processo. São Paulo: Lemos e Cruz, 2003. p. 150.

${ }_{188}$ OLIVEIRA, Carlos Alberto Alvaro de. Do formalismo no processo civil, p. 147.

${ }^{189}$ HOMBURGUER, Adolf. Functions of Orality in Austrian and American Civil Procedure. Buffalo Law Review, n. 20, 1970, p. 39.

${ }^{190}$ CHIOVENDA, Giuseppe. Relazione su progetto di riforma del procedimento elaborato dalla Coomissione per il dopo guerra, p. 51. Tal posição coincide com a de KLEIN, Franz. Vorlesungen über die Praxis des Civilprocess, p. 123.

${ }^{191}$ GAJARDONI, Fernando da Fonseca. Técnicas de aceleração do processo, p. 150.

192 BARBOSA MOREIRA, José Carlos. Vicissitudes da audiência preliminar, p. 140. FERNANDO GAJARDONI apresenta alguns dados de uma pesquisa de opinião por ele mesmo realizada em setembro de 2001, entre juízes de varas cíveis, atuantes no Foro Central da Capital de São Paulo, acerca de sua percepção sobre nível de acordos realizados na audiência do artigo 331 do CPC. Constatou-se que 43\% dos juízes entrevistados tinham a percepção de que o percentual de acordos na referida audiência estaria em torno de $10 \%$ ou menos do total de processos. Apesar de se tratar de uma mera pesquisa de opinião, e não de uma
} 
As experiências recentes da Áustria e da Alemanha pendem em favor do regime facultativo. Na Alemanha a opção entre a fase preliminar escrita (schriftliches Vorverfahren), mediante a troca de peças escritas (Schriftsätze), ou de forma oral, com a designação de uma ou mais audiências preliminares (fhrüher erste Termin), é uma escolha realizada pelo juiz, com base em critérios pragmáticos e de conveniência. ${ }^{193}$

Observe-se que esta escolha é feita logo após o ajuizamento da demanda, antes mesmo da resposta do réu, e não configura uma decisão em sentido estrito - não havendo que em se falar em preclusão -, mas mero ato de gerenciamento do processo. Posteriormente, caso alguma das partes se sinta insatisfeita com o método de desenvolvimento da fase preliminar escolhida pelo juízo, é possível pleitear sua reconsideração, seja para requer a realização da audiência preliminar, seja para cancelá-la, expondo-se as razões pelas quais entende que o método pretendido seria mais eficaz. ${ }^{194}$

Demais disso, é preciso notar que na Alemanha a importância da audiência preliminar é mitigada nas ações que envolvem a cobrança pecuniária pelo uso da Mahnverfahren (\$278 da ZPO). ${ }^{195}$ De igual modo, na Áustria, desde 1983, nas causas envolvendo cobrança pecuniária até um determinado valor, o procedimento não tem em seu início uma audiência preliminar (erste Tagsatzung), mas sim a expedição de um mandado de injunção obrigatório (Mahnverfahren), mitigando a tradicional oralidade no procedimento. ${ }^{196}$ Deveras, segundo dados citados por RECHBERGER-KLICKA, na Áustria, são emitidas por ano cerca de 700.000 ordens de pagamento (Mahnverfahren), sendo que em mais de $90 \%$ dos casos o devedor honra sua dívida sem levantar objeções. ${ }^{197}$

pesquisa estatística propriamente dita, tal dado acena para baixos níveis de acordo neste momento processual. GAJARDONI, Fernando da Fonseca. Técnicas de aceleração do processo, Anexo IV, p. 237.

193 Na prática a forma escrita prevalece, segundo afirma LEIPOLD, Dieter. Oral and Written Elements within the Introductory Phase of Civil Proceedings, p. 75.

194 MURRAY, Peter; STÜRNER, Rolf. German Civil Justice, p. 212-213. No mesmo sentido LEIPOLD, Dieter. Oral and Written Elements within the Introductory Phase of Civil Proceedings, p. 62.

${ }^{195}$ BREYER. Relatório alemão apresentado ao painel Novas Tendências nos Procedimentos Preliminares, do XIII Congresso Mundial de Direito Processual (Brasil-2007) apud ANDREWS, Neil. The pre-actionphase - General Report - Common Law. In: GRINOVER, Ada Pellegrini; CALMON, Petrônio (Org.). Direito Processual Comparado. XIII World Congress of Procedural Law. Rio de Janeiro: Forense, 2007. p. 211 , nota 47.

196 KÖNIG, Bernhard. La ZPO Austriaca dopo la Novella del 1983. Rivista di Diritto Processuale, Padova, Cedam, n. 3, 1988. p. 716-717. OBERHAMMER, Speeding Up Civil Litigation in Austria, cit., p. 229. Em 2003, o limite para a obrigatoriedade da Mahnverfahren foi aumentado de $€ 10,000$ (dez mil euros) para $€$ 30,000 (trinta mil euros).

${ }^{197}$ KLICKA, Thomas; RECHBERGER, Walter. Accelerating Civil Litigation in Austria in the Twentieth Century. In: RHEE, C. H. van (Org.). The Law's Delay: Essays on Undue Delay in Civil Litigation. Intersentia, 2004. p. 237. 
Demais disso, é preciso lembrar que na Áustria o princípio da oralidade possui status constitucional. Não obstante, o que se verifica é uma tendência em racionalizar o emprego da oralidade no procedimento.

Ainda, vale notar que a importância dada à audiência preliminar (früher erste Termin) no Modelo de Stuttgart não pode ser interpretada de forma dissociada do fato de que, neste modelo, antes da audiência, o juiz e as partes possuem muito mais elementos para aproveitamento máximo deste ato do que no sistema brasileiro. Segundo o Modelo de Stuttgart, após a introdução escrita da demanda, citação e resposta do réu, o juiz deve analisar a petição inicial, contestação e réplica, determinando as medidas urgentes e os esclarecimentos que entender necessários. ${ }^{198}$ Após o cumprimento do que for eventualmente determinado pelo juiz, as partes são informadas da data da audiência preliminar (früher erste Termin) e da inclinação do juízo sobre as matérias jurídicas em discussão ${ }^{199}$ (é preciso ter em mente que o §278 (2) da ZPO permite ao juiz expor suas impressões sobre as matérias de fato e de direito ao longo do procedimento).

Deveras, dados estatísticos recolhidos na Bavária em 1972 apontam a existência de uma relação direta entre a duração do processo e a preparação adequada para a audiência preliminar (früher erste Termin). Verificou-se que, quando o juiz preparou o processo de forma mais intensa para a audiência preliminar nos moldes do Modelo de Stuttgart, com a presença das partes, havendo prévio estabelecimento das diretivas a serem tomadas quanto à produção da prova (§272B da ZPO), em 25\% dos casos o procedimento em primeira instância durou menos de três meses e em 58\% a duração ficou entre três e seis meses. Já nos casos em que não houve preparação alguma para a audiência preliminar, estes percentuais ficaram reduzidos a $2 \%$ e $12 \%$, respectivamente. $^{200}$

Além disso, não se pode perder de vista que a eficiência do sistema judicial alemão não pode ser explicada apenas com base na valorização da audiência preliminar, sem considerar, por exemplo, o elevado rigor do processo seletivo de novos juízes - recrutando-se profissionais com habilidades técnicas muito acima da média -, o

\footnotetext{
198 BENDER, Rolf. The Stuttgart Model, p. 449-450. Já a Alemanha não constitucionalizou oralidade no processo. BAUR, Fritz. Les Garanties Fondamentales des Parties dans le Procés Civil em République Fédérale d’Allemagne, p. 22.

199 BENDER, Rolf. The Stuttgart Model, p. 451.

200 Dados estatísticos do Estado da Bavária, citados por BENDER, Rolf. The Stuttgart Model, p. 464.
} 
elevado nível dos profissionais da área jurídica em geral - fruto de um sistema de educação superior de alto padrão $0^{201}$-, e o elevado número de juízes per capita. ${ }^{202}$

Até mesmo Portugal, que adotou um esquema de audiência preliminar espelhado no artigo 301 do Código Modelo de Processo Civil para a América Latina, ${ }^{203}$ tal como o Brasil, optou pelo regime facultativo. Conforme dispõe o artigo 508B, do Código de Processo Civil Português, a dispensa da audiência preliminar no processo ordinário pode ocorrer quando, destinando-se à fixação da base instrutória, a simplicidade da causa o justifique, ou quando a sua realização tivesse como fim facultar a discussão de excepções dilatórias já debatidas nos articulados ou do mérito da causa, nos casos em que a sua apreciação revista manifesta simplicidade.

No Japão, o modo de desenvolvimento da fase preliminar também fica a critério discricionário do juiz. MANABU HONMA afirma que as partes podem influenciar esta decisão, mas o dever de estruturar o procedimento é do juiz. Na prática, relata o autor que na maioria esmagadora dos casos, o juiz escolhe a forma oral. Todavia, é interessante notar que optando o juiz pela via escrita, ou seja, pelo procedimento preparatório baseado em documentos (Shomen-ni-yoru-Junbi-Tetsuzuki) previsto nos artigos 175-178 do Código de Processo Civil, admite-se uma conferência por telefone entre juiz e advogados, com o escopo de organizar a fase instrutória, de modo que a importância da escrita acaba sendo muito reduzida neste momento do procedimento. ${ }^{204}$

Esta prevalência da preparação oral pode ser entendida se for levado em consideração o fato de que a Reforma de 2003 do Código de Processo Civil do Japão deu especial ênfase ao estabelecimento de um cronograma dos atos de instrução que devem ser realizados, o que é feito pelo juiz, juntamente com as partes. MANABU HONMA relata que esta técnica de case management contribuiu para uma redução significativa do tempo de duração dos processos, com exceção daqueles que envolvem fatos muito complexos, tais como os de responsabilidade civil por erro médico. ${ }^{205}$

\footnotetext{
201 MURRAY, Peter; STÜRNER, Rolf. German Civil Justice, p. 8, 10.

202 Em 31 de dezembro de 2007 existiam na Alemanha 20.138 juízes, o que significa 24,49 juízes por cem mil habitantes. Fonte: STATISTISCHES BUNDESAMT DEUTSCHLAND. Statistische Jahrbuch 2008 für die Bundesrepublik Deutschland, capítulo 10 (Justiz). Disponível em: <www.destatis.de>. Acesso em: 09 jul. 2009. No Brasil, no ano de 2008, o número de juízes por cem mil habitantes era de apenas 8,38 (0,78 da Justiça Federal; 1,7 da Justiça do Trabalho, e 5,9 da Justiça Estadual). Fonte: CONSELHO NACIONAL DE JUSTIÇA. Justiça em Números 2008. Disponível em: <www.cnj.jus.br>. Acesso em: 09 jul. 2009.

203 GERALDES, António Santos Abrantes. Temas da Reforma do Processo Civil. v. II. 4. ed. Coimbra: Almedina, 2004. p. 85.

${ }^{204}$ HONMA, Manabu. The Preliminary Phase and the Trial Agreement in Japan, p. 258.

205 HONMA, Manabu. The Preliminary Phase and the Trial Agreement in Japan, p. 259.
} 
Na Itália, o esforço do legislador em prestigiar a oralidade na fase preliminar tem sido em vão. TARUFFO afirma que as recentes reformas que trataram da udienza di prima tratazione foram redigidas de forma tão infeliz que, na prática, a audiência do artigo 183 do Codice di Procedura Civile é utilizada apenas para a fixação da data para a entrega das manifestações escritas, não tendo os juízes desempenhado nenhuma função gerencial nesta fase, deixando com que a fase preliminar se desenvolva de modo totalmente escrito. ${ }^{206}$

Na Itália, nem mesmo os processos envolvendo causas de menor valor seguem a oralidade. Segundo TARUFFO, A oralidade a deformalização preconizadas pelo artigo 320 do CPC italiano ficam apenas no plano da teoria, sendo que na prática têm sido observadas as mesmas formalidades do procedimento ordinário. ${ }^{207}$

Todavia, é importante registrar duas desvantagens possíveis de um procedimento no qual é dado ao juiz maior discricionariedade na designação ou não de uma audiência preliminar. Da perspectiva do advogado, existe o problema da incerteza quanto ao procedimento, que poderia oscilar de acordo com o modo de trabalho de cada magistrado. Do ponto de vista da administração do cartório judicial, há de se notar que quanto maior é a customização de tratamento a ser aplicado a cada espécie de demanda, maior será a dificuldade do servidor em seguir as rotinas de trabalho estipuladas pelo juiz, e consequentemente maior será o número de erros cometidos pelos servidores, e assim mais demorado será o cumprimento do expediente pelo cartório.

Trata-se do mesmo fenômeno que ocorre em relação aos procedimentos especiais. Na administração do cartório judicial, observa-se maior dificuldade dos servidores em lidar com aqueles processos de procedimentos especiais com ritos diferenciados, principalmente em matérias pouco recorrentes.

Todavia, alguma customização do procedimento é essencial para o aumento de eficiência na prestação jurisdicional, levando-se em consideração o número de

\footnotetext{
${ }^{206}$ TARUFFO, Michele. Orality and writing as factors of efficiency in civil litigation, p. 192. Sendo esta realmente a realidade italiana, a assertiva de NELSON NERY JÚNIOR no sentido de que a técnica da prima udienza trattazione seria superior à da audiência do artigo 331 do CPC deixou de ser verdadeira com a reforma promovida pela Lei n. 10.444/2002. O fato de o legislador italiano manter essa audiência sem a obrigatoriedade do comparecimento das partes, mas apenas de seus advogados, nas demandas que versam sobre direito indisponível, para a realização de atividades que poderiam ser realizadas por escrito sem que haja prejuízo, rigorosamente, não é um avanço, mas, ao contrário, representa um elemento de burocratização das atividades judiciais. NERY JÚNIOR, Nelson. Audiência Preliminar e Saneamento do processo. In: TEIXEIRA, Sálvio Figueiredo (Coord.). Reforma do Código de Processo Civil. São Paulo: Saraiva, 1996. p. 340.

${ }^{207}$ TARUFFO, Michele. Orality and writing as factors of efficiency in civil litigation, p. 193.
} 
processos da vara, a disponibilidade da pauta de audiências, e a existência de recursos de estenotipia e gravação. É o caso, por exemplo, do procedimento da Lei de Alimentos (Lei n. $5.478 / 68)$.

A concentração procedimental proposta na Lei n. 5.478/68 pode ou não ser eficiente de acordo com as condições e recursos de cada comarca. Deveras, a concentração da tentativa de conciliação, instrução, debates e julgamento para um mesmo ato, tal qual concebida pelo legislador, por vezes mostra-se ineficiente, sob uma perspectiva de gerenciamento de processos.

É claro que da perspectiva estritamente individual, a concentração de todos os atos do processo numa mesma audiência mostra-se mais célere. Todavia, no caso específico da demanda envolvendo alimentos, segundo o critério de racionalização de tempo, esta concentração pode se revelar ineficiente. A designação de uma audiência com o propósito específico de conciliação permite que este ato seja presidido por um conciliador especialmente capacitado para este fim, reservando-se a pauta do juiz togado apenas para as audiências de instrução.

De outra banda, as alegações finais orais previstas no artigo 11 da Lei n. 5.478/68 podem, sem maiores prejuízos, ser substituídas por memoriais escritos, com ganhos significativos no aspecto de otimização do tempo em audiência, sobretudo em situações nas quais a Defensoria Pública responde por parcela significativa da pauta de audiência, não sendo razoável exigir do defensor público que esteja preparado para sustentar oralmente suas razões em dezenas de feitos num mesmo dia.

De igual modo, a previsão do parágrafo único do artigo 11 da referida lei, no sentido de que o juiz ditará a sua sentença, também traz uma previsão de aplicabilidade prática restrita aos casos de maior simplicidade e para as comarcas nas quais não há sobrecarga na pauta de audiência.

Adotado à risca o procedimento previsto na Lei n. 5.478/68 - com uma audiência única para tentativa de conciliação, oitiva de testemunhas, depoimento das partes, debates, e julgamento - a pauta de audiência não poderia suportar mais do que cinco audiências por tarde. De outro lado, admitida a separação da tentativa de conciliação dos atos instrutórios, bem como oportunizada as alegações finais por meio de memoriais escritos, é possível que cerca de duas dezenas de demandas sejam apreciadas num mesmo dia. 
Ora, o gerenciamento de processos pressupõe alguma margem de mobilidade ao juiz para customizar o procedimento em razão de variantes de sua realidade particular. Por exemplo, a porcentagem de mandados de intimação não cumpridos - que oscila de acordo com o tamanho da comarca, zelo dos oficiais de justiça e características econômicas da região - pode inclusive ser determinante para o insucesso de um procedimento muito concentrado.

\subsection{AS DEMANDAS DE PEQUENO VALOR E A FACULTAVIDADE DA AUDIÊNCIA}

A designação de uma audiência importa custos que as partes não teriam caso fosse determinado um procedimento totalmente escrito. Assim, discute-se acerca da conveniência da designação de audiências em demandas que envolvem pequenos valores.

Na Alemanha, praticamente não há diferença entre o procedimento da Amtsgericht e o da Landsgericht. ${ }^{208}$ Todavia, nas demandas de valor inferior a 600 euros perante às Amtsgerichte, o §495A da ZPO, com a redação que lhe foi determinada pela Zivilprozessreformgesetz de 27 de julho de 2001, permite ao juiz conformar o procedimento de acordo com sua discricionariedade equitativa (Verfahren nach billigem Ermessen). Na prática, os juízes usam este dispositivo para não designar a audiência preliminar e, não havendo necessidade de prova testemunhal, determinar um procedimento inteiramente escrito. ${ }^{209}$

Já a Espanha segue um caminho completamente diverso com o seu juicio verbal para as demandas de até 3000 euros.

É interessante observar que o Processo Europeu Para Ações de Pequeno Montante (European Small Claim Procedure - ESCP), introduzido pelo Regulamento (CE) n. 861 de 11 de julho de 2007 do Parlamento Europeu ${ }^{210}$, que entrou em vigor no ano de 2009 em todos os Estados da União Europeia, com exceção da Dinamarca, estabelece um procedimento no qual a designação de uma audiência é

\footnotetext{
208 LEIPOLD, Dieter. Oral and Written Elements within the Introductory Phase of Civil Proceedings, p. 63. 209 LEIPOLD, Dieter. Oral and Written Elements within the Introductory Phase of Civil Proceedings, p. 63. 210 Disponível em <www.europa.eu/legislation_summaries/consumers/protection_of_consumers/ 116028_en.htm>. Acesso em: 31/07/2009.
} 
subordinada a um juízo de conveniência por parte do juiz, que pode recusar o pedido de designação de audiência, mediante decisão escrita e fundamentada, se entender que uma audiência seria claramente desnecessária para assegurar um processo equitativo. ${ }^{211}$

É claro que neste caso a própria natureza transfronteiriça do litígio desestimula, de certa forma, o estabelecimento de um procedimento por audiências, que poderia encarecer demasiadamente o processo, criando obstáculos ilegítimos para o acesso à justiça. Todavia, este procedimento não deixa de ser um paradigma interessante para o processualista brasileiro, notadamente se forem consideradas as proporções continentais do país.

Neste esteio, o artigo $5^{\circ}$ do Regulamento (CE) n. 861/2007 do Parlamento Europeu dispõe que o processo europeu para ações de pequeno montante é escrito, dando ampla margem de liberdade para o magistrado designar ou não uma audiência, exigindo apenas que esta escolha seja devidamente fundamentada. ${ }^{212}$ Demais disso, sendo designada uma audiência, o Regulamento não exclui a possibilidade de que esta seja realizada mediante videoconferência ou outras tecnologias de comunicação se estiverem disponíveis os meios técnicos necessários. ${ }^{213}$

A experiência brasileira dos Juizados Especiais Cíveis, no esteio do juicio verbal espanhol, adota um tratamento eminentemente oral para as demandas de pequeno valor, por força do artigo 98, inciso I, da Constituição da República.

Ocorre que o critério mais adequado para se determinar se uma demanda há de seguir um procedimento mais oral ou mais escrito não é o valor do bem da vida em discussão, mas sim a natureza dos pontos controvertidos, o que evidentemente não pode ser definido a priori.

De outra banda, há de se ter em vista que a oralidade no âmbito dos Juizados Especiais Cíveis é determinada em grande medida pela tentativa de conciliação, e não em benefício da instrução ou do esclarecimento da demanda.

${ }^{211}$ DIETER LEIPOLD entende que este dispositivo viola o artigo $6^{\circ}$, $§ 1^{\circ}$, da Convenção Europeia para Salvaguarda dos Direitos dos Homens e Liberdades Fundamentais. Na visão do autor, o pedido de alguma das partes para a designação de uma audiência não poderia ser negado pelo juiz. LEIPOLD, Dieter. Oral and Written Elements within the Introductory Phase of Civil Proceedings, p. 63.

${ }^{212} 1$. O processo europeu para acções de pequeno montante é escrito. O órgão jurisdicional pode efectuar uma audiência, se o considerar necessário ou se uma das partes o requerer. O órgão jurisdicional pode indeferir este pedido se, após apreciação das circunstâncias do caso, concluir que uma audiência é claramente desnecessária para assegurar um processo equitativo. $O$ indeferimento deve ser justificado por escrito, e não pode ser impugnado separadamente.

${ }^{213}$ art. $9^{\circ}$, (1), do Regulamento (CE) n. 861/2007 do Parlamento Europeu. 


\section{ORALIDADE E A TENTATIVA DE CONCILIAÇÃO}

A tentativa de conciliação, seja como requisito para propositura da demanda (pre-action) - admitida em alguns poucos sistemas -, seja como atividade a ser promovida pelo juiz na fase preliminar (pre-trial) - prevista na maioria dos ordenamentos -, é um tema que gera grande polêmica no que tange à questão da racionalização do trabalho em primeira instância.

Quanto à natureza jurídica deste meio de composição de litígios, também paira alguma incerteza. Por exemplo, MARCATO entende que a conciliação é uma forma de heterocomposição, porquanto exige a participação de um terceiro, o conciliador. Para o autor, a conciliação se distingue da transação, que, ao prescindir da intervenção de um terceiro, se configura numa forma de autocomposição do litígio. ${ }^{214}$ Todavia, esta posição desconsidera o fato de que na conciliação não é um terceiro que encontra uma solução para o litígio ${ }^{215}$, mas sim as próprias partes, atuando o conciliador como mero catalisador. Como bem afirma MICCOLIS, a conciliação fica a meio caminho entre a arbitragem, típico meio heterocompositivo, e a transação, meio autocompositivo na acepção mais estrita do termo. ${ }^{216}$ Doravante, tratar-se-á da conciliação e da mediação no mesmo patamar, porquanto a diferença entre estes institutos não é tão relevante para os fins deste estudo.

Deixando de lado esta questão secundária, a maior polêmica gira em torno do caráter obrigatório ou facultativo da tentativa de conciliação. Deveras, neste particular, raros são os sistemas nos quais se pode observar um consenso sobre este assunto, ao que se acrescenta o fato de que não é possível identificar correntes uniformes sobre este tema numa perspectiva comparativa. Assim, neste tópico analisar-se-ão algumas experiências estrangeiras ligadas à conciliação e à mediação, buscando delas extraírem-se elementos para a melhor compreensão da conciliação no sistema processual civil brasileiro.

\footnotetext{
${ }^{214}$ MARCATO, Antonio Carlos. Comentário 5 ao art. 331 do CPC. In: Civil Interpretado. São Paulo: Atlas, 2004. p. 987.

${ }^{215}$ LUISO, Francesco. La conciliazione nel quadro della tutela dei diritti. In: Studi in Onore di Giuseppe Tarzia. t. 2. Milano: Giuffrè, 2005. p. 2059-2060.

${ }^{216}$ MICCOLIS, Giuseppe. La conciliazione e la disciplina del nuovo processo introdotto con il D.Lgs. n. 5 del 2003. In: Studi in Onore di Giuseppe Tarzia. t. 2. Milano: Giuffrè, 2005. p. 2080. (Org.). Código de Processo
} 


\subsection{MEDIAÇÃO PRÉ-PROCESSUAL OBRIGATÓRIA NA ALEMANHA (\$15 DA EGZPO)}

As restrições orçamentárias no final da década de 1990 na Alemanha, que impossibilitavam o aumento do número de juízes e da estrutura do Judiciário, e o crescimento galopante do número de litígios após a reunificação do país, impulsionaram medidas tendentes a simplificar e baratear o processo. Nesta linha, foram formuladas propostas para diminuir o uso de órgãos colegiados em primeiro grau, limitar as hipóteses de revisão da matéria de fato em segundo grau, opor barreiras processuais para o acesso às cortes superiores, e reafirmar o dever do juiz em promover a conciliação entre as partes. $^{217}$

Assim, em 1999 uma lei federal alterou o $§ 15$ da Lei de Introdução à ZPO (Gesetz betreffend die Einführung der ZPO - EGZPO), para autorizar os estados alemães (Bundesländer) a imporem uma mediação pré-processual (pre-action) obrigatória perante as Amtsgerichte nas ações de cobrança de valor inferior a 750 euros, em alguns casos que envolvem direitos de vizinhança, entre outras hipóteses, tendo 8 de 16 Bundesländer adotado tal medida.

Todavia, esta mediação obrigatória acabou sendo evitada na prática nas causas envolvendo uma cobrança pecuniária pelo uso da Mahnverfahren, que, grosso modo corresponde à nossa ação monitória, e nos demais casos pela aplicação do $\S 278$ da $Z P O$, que permite ao juiz, mediante requerimento das partes, dispensar tal medida caso o acordo entre as partes lhe pareça improvável. ${ }^{218}$

Como acentua GERHARD WALTER, o impacto desta nova regra foi deveras limitado, porquanto são exatamente as cobranças de pequeno valor que tipicamente são pagas na primeira oportunidade no procedimento da Mahnverfahren. Além disso, há de se considerar que o sub-parágrafo 5 do $\$ 15$ da EGZPO permite que as Bundesländer estabeleçam outras exceções à conciliação obrigatória, fato que diminui ainda mais o escopo de aplicação deste dispositivo. ${ }^{219}$

217 GOTTWALD, Peter. Civil Procedure Reform in Germany. American Journal of Comparative Law, $\mathrm{n}$. 45, 1997. p. 753-757.

${ }^{218}$ BREYER. Relatório alemão apresentado ao painel Novas Tendências nos Procedimentos Preliminares, do XIII Congresso Mundial de Direito Processual (Brasil-2007) apud ANDREWS, Neil. The pre-actionphase - General Report - Common Law, p. 211, nota 47.

${ }^{219}$ WALTER, Gerhard. The German Civil Procedure Reform Act 2002: Much ado about nothing? In: Studi di Diritto Processuale Civile in Onore di Giuseppe Tarzia. Milano: Giuffrè, 2005. p. 797. 
Outro óbice é que, na prática, conforme afirma DIETER LEIPOLD, os próprios advogados na Alemanha, antes de ajuizarem uma demanda, já tinham o hábito de entrar em contato com a parte contrária para saber se haveria a possibilidade de um acordo. Nestes termos, estabelecer uma tentativa obrigatória de conciliação logo no início da demanda dificilmente daria bons frutos. ${ }^{220}$

Aliás, vale anotar que se discute no parlamento alemão se seria conveniente abolir simplesmente esta conciliação obrigatória, que não gerou até agora bons resultados. ${ }^{221}$

Numa perspectiva histórica, é interessante lembrar que esta não foi a primeira vez que o legislador alemão insistiu na conciliação obrigatória, assim como não foi a primeira vez que esta ideia foi rechaçada pela prática judicial. A reforma processual de 1924, cuja tônica foi a inserção de diversos elementos importados da ZPO austríaca de 1895, introduziu na Alemanha a conciliação obrigatória, que foi abolida com a Novelle de 1950 em razão de seu insucesso. ${ }^{222}$

\subsection{MEDIAÇÃO PRÉ-PROCESSUAL OBRIGATÓRIA EM ONTÁRIO}

No Canadá, a província de Ontário introduziu, em janeiro de 1999, a mediação pré-processual obrigatória em todos os processos civis nas cidades de Toronto e Ottawa, tendo a regra sido ampliada para toda a província em $2001 .^{223}$ Todavia, conforme narra JACOBS, este procedimento criou diversos problemas. Por exemplo, nas demandas fundadas em responsabilidade civil, observou-se que a mediação em momento tão prematuro em geral não surtia bons resultados, pois muitas vezes ainda não haviam sido produzidas todas as consequências do ato lesivo. Nos casos envolvendo

\footnotetext{
${ }^{220}$ LEIPOLD, Dieter. Oral and Written Elements within the Introductory Phase of Civil Proceedings, p. 73.

221 WALTER, Gerhard. The German Civil Procedure Reform Act 2002, p. 815.

${ }^{222}$ WALTER, Gerhard. The German Civil Procedure Reform Act 2002, p. 796.

223 COLLEEN HANYCZ. Relatório canadense ao painel Novas Tendências nos Procedimentos Preliminares, do XIII Congresso Mundial de Direito Processual (Brasil-2007) apud ANDREWS, Neil. The pre-action-phase - General Report - Common Law, p. 208, nota 31.
} 
litisconsórcio, algum tumulto processual também poderia ocorrer em decorrência da conciliação pré-processual obrigatória. ${ }^{224}$

Em Ontário, segundo JACOBS, os níveis de acordo nas mediações obrigatórias não ultrapassavam 40\%, ao passo que nos casos em que as partes voluntariamente se dispunham a buscar uma solução amigável ao litígio esse percentual ultrapassava os 75\%. Neste esteio, em 2004, por ocasião da nomeação de um novo Regional Senior Judge para Toronto, este sistema de mediação obrigatória foi repensado, considerando-se os níveis insatisfatórios de acordos decorrentes da mediação obrigatória, a escassez de pessoal capacitado para conduzir um elevado número de mediações, e a falta de verbas do tribunal para este propósito. ${ }^{225}$

Assim, a mediação pré-processual obrigatória em Toronto foi suspensa temporariamente desde $1^{\circ}$ de janeiro de 2005, por ter se demonstrado um método excessivamente oneroso e ineficiente. ${ }^{226}$

É interessante notar que entre os países estudados no painel Novas Tendências nos Procedimentos Preliminares, do XIII World Congress of Procedural Law de 2007 (África do Sul, Alemanha, Argentina, Áustria, Austrália, Bélgica, Brasil, Canadá, Dinamarca, Espanha, Estados Unidos, Finlândia, França, Grécia, Holanda, Islândia, Israel, Itália, Japão, Noruega, Portugal, Suécia e Suíça), apenas a província de Ontário no Canadá (com a ressalva da suspensão da obrigatoriedade quanto à cidade de Toronto, conforme acima relatado), Suíça ${ }^{227}$ e Noruega ${ }^{228}$ adotam a mediação pré-processual obrigatória como regra geral nas demandas civis. $^{229}$

224 JACOBS, Paul. A Recent Comparative History of Mandatory Mediation vs Voluntary Mediation in Ontario, Canada. International Bar Association Mediation Newsletter, abr. 2005. Disponível em: <www.msmlaw.net/Resources/Mandatory.vs.Voluntary.Media.pdf>. Acesso em: 22 jul. 2009. p. 1-2.

${ }^{225}$ JACOBS, Paul. A Recent Comparative History of Mandatory Mediation vs Voluntary Mediation in Ontario, Canada, p. 2.

226 JACOBS, Paul. A Recent Comparative History of Mandatory Mediation vs Voluntary Mediation in Ontario, Canada, p. 2.

227 A Sühnverfahren (procedimento de conciliação), conforme reporta TANJA DOMEJ, da Universidade de Zurique, em muitos cantões é conduzida por juízes de paz, que gozam de uma longa tradição na Suíça, e desempenham importante papel na justiça civil do país. Relatório suíço ao painel Novas Tendências nos Procedimentos Preliminares, do XIII Congresso Mundial de Direito Processual (Brasil-2007) apud ANDREWS, Neil. The pre-action-phase - General Report - Common Law, p. 209-210, notas 38 a 43.

${ }^{228}$ LAURA ERVO. Relatório norueguês apresentado ao painel Novas Tendências nos Procedimentos Preliminares, do XIII Congresso Mundial de Direito Processual (Brasil-2007) apud ANDREWS, Neil. The pre-action-phase - General Report - Common Law, p. 209, notas 33 a 37.

${ }^{229}$ Brasil e Itália, em determinadas situações, adotam um regime de conciliação prévia obrigatória no processo do trabalho. Na França, adota-se a conciliação prévia obrigatória em algumas hipóteses de jurisdictions d'exception, tais como os casos julgados pelo conseil de prud'hommes e pelo tribunal de baux ruraux. CÉCILE CHAINAIS. Relatório francês apresentado ao painel Novas Tendências nos Procedimentos Preliminares, do XIII Congresso Mundial de Direito Processual (Brasil-2007) apud ANDREWS, Neil. The 
No Brasil, JOSÉ ROBERTO DOS SANTOS BEDAQUE afirma que a imposição por lei de qualquer medida extrajudicial prévia de natureza obrigatória violaria o artigo 50, inciso XXXV, da Constituição Federal. ${ }^{230}$ Deveras, tendo em vista apenas a distribuição cronológica do trabalho, pouca diferença existe entre a conciliação ou mediação pré-processual obrigatória e aquela desenvolvida de forma obrigatória após a propositura da demanda. Todavia, considerando o sistema constitucional brasileiro, assiste plena razão ao autor.

\subsection{CONCILIAÇÃO OBRIGATÓRIA E FLEXIBILIDADE DO PROCEDIMENTO NA ALEMANHA: A GÜTEVERHANDLUNG E AS REFORMAS DE 2001 DA ZPO}

As reformas de 2001 na ZPO introduziram a obrigatoriedade de uma tentativa de conciliação (Güteverhandlung) a ser realizada antes de qualquer audiência (pre-trial), salvo se o juiz considerar que tal ato restará infrutífero (... erscheint erkennbar aussichtslos), com o propósito de aumentar os percentuais de conciliação. ${ }^{231}$

Neste sentido, passa a ser dever formal do juiz buscar uma solução amigável para o litígio. O juiz alemão, nessa perspectiva, deve buscar a conciliação das partes, em relação a todo o litígio ou quanto a pontos particulares, em todas as fases do procedimento (ZPO, §278 (1). Das Gericht soll in jeder Lage des Verfahrens auf eine gütliche Beilegung des Rechtsstreits oder einzelner Streitpunkte bedacht sein - "em todas as fases do procedimento, a corte deve atentar para a possibilidade de um acordo amigável entre as partes, seja em relação ao conflito jurídico central, seja em relação a questões pontuais da contenda”). Reforçando esta ideia, as reformas de 2001 introduziram

pre-action-phase - General Report - Common Law, p. 212, nota 48. No Japão, as demandas envolvendo direito de família são submetidas à mediação obrigatória. MASANORI KAWANO. Relatório japonês apresentado ao painel Novas Tendências nos Procedimentos Preliminares do XIII Congresso Mundial de Direito Processual (Brasil-2007) apud ANDREWS, Neil. The pre-action-phase - General Report - Common Law, p. 218, nota 80.

${ }^{230} \mathrm{O}$ autor ressalva o caso da justiça desportiva (art. 217, $\S 1^{\circ}, \mathrm{CF}$ ). BEDAQUE, José Roberto dos Santos. Novas Tendências em matéria de fase preliminar - Relatório de Síntese. In: GRINOVER, Ada Pellegrini; CALMON, Petrônio (Org.). Direito Processual Comparado. XIII World Congress of Procedural Law. Rio de Janeiro: Forense, 2007. p. 259.

${ }^{231}$ MURRAY, Peter; STÜRNER, Rolf. German Civil Justice, p. 246. 
a tentativa obrigatória de conciliação (Güteverhandlung), inspirada na experiência da justiça do trabalho alemã. ${ }^{232}$

Na prática, o que se observa é que esta tentativa de conciliação ocorre no início da audiência preliminar (früher erster Termin), ou da audiência principal (Hauptterminin) quando a fase preliminar é realizada de forma escrita (schriftliches Vorverfahren), consistindo em alguns casos numa mera menção por parte do juiz das vantagens da composição amigável, ou, em outros, em uma postura mais ativa do juiz, que chega até mesmo a expor suas impressões iniciais sobre o caso $^{233}$, propondo às partes termos específicos de acordo, o que é permitido segundo o $\$ 275$ da $Z P O{ }^{234}$

Esta reforma repercutiu negativamente na doutrina, sob o argumento de que pouco se ganha com a obrigatoriedade da tentativa de conciliação, em prejuízo da desejada flexibilidade do procedimento. ${ }^{235}$ Demais disso, conforme sustenta RÜHL, o caráter obrigatório da Güteverhandlung parece conflitar com a voluntariedade que é ínsita à autocomposição de litígios. ${ }^{236}$

Parece que a preocupação da doutrina alemã é com o fato de que o direito do cidadão a um julgamento justo não pode ser ameaçado por pressões econômicas, processuais e judiciais no sentido de compelir o jurisdicionado a um acordo muitas vezes indesejado. $^{237}$

\footnotetext{
${ }^{232}$ STADLER, Astrid. The multiples roles of Judges and Attorneys in Modern Civil Litigation. Hastings International and Comparative Law Review, n. 27, 2003. p. 72. DIETER LEIPOLD afirma que o significativo número de acordos obtidos na justiça do trabalho não pode ser parâmetro para a justiça comum. A natureza patrimonial da generalidade dos litígios na justiça trabalhista poderia explicar o maior êxito da conciliação nesta justiça especializada. LEIPOLD, Dieter. Oral and Written Elements within the Introductory Phase of Civil Proceedings, p. 72.

${ }^{233} \mathrm{O}$ §278 (2) da ZPO permite que o juiz expresse livremente suas impressões sobre o substrato fático e de direito envolvido no litígio, podendo ainda fazer perguntas às partes. Das Gericht hat in der Güteverhandlung den Sach - und Streitstand mit den Partein unter freier Würdigung aller Umstände zu erörtern und, soweit erforderlich, Fragen zu stellen.

${ }^{234}$ MURRAY, Peter; STÜRNER, Rolf. German Civil Justice, p. 260. A tentativa de conciliação (Güteverhandlung) pode ser agendada para uma data diversa da audiência preliminar (früher erster Termin) e da audiência principal (Haupttermin) se tal circunstância aumentar as chances de obtenção de um acordo. RÜHL, Giesela. Preparing Germany for the $21^{\text {st }}$ Century: The Reform of the Code of Civil Procedure. German Law Journal, v. 6, n. 6, jun. 2005. p. 914. Disponível em: <www.germanlawjournal.com>. Acesso em: 09 jul. 2009.

${ }^{235}$ MURRAY, Peter; STÜRNER, Rolf. German Civil Justice, p. 248. Os resultados desta reforma de 2001 são questionáveis, conforme relata RÜHL, Giesela. Preparing Germany for the $21^{\text {st }}$ Century, p. 914.

${ }^{236}$ RÜHL, Giesela. Preparing Germany for the $21^{\text {st }}$ Century, p. 914.

${ }^{237}$ MURRAY, Peter; STÜRNER, Rolf. German Civil Justice, p. 488.
} 
Deveras, STADLER afirma que a conciliação não é o objetivo primário do Judiciário, cuja imagem fica manchada se as partes tiverem a impressão de que o acordo não se baseia completamente em sua livre vontade. ${ }^{238}$

Na mesma linha, SCHELLHAMMER afirma que o juiz que força as partes a se conciliarem desvirtua o seu poder, denegando-lhes o direito a um julgamento justo, garantido pelo artigo 92 da Constituição Alemã. É por meio das decisões judiciais que o direito se preserva, e é somente pelo ato de julgar que o juiz pode garantir a aplicação do direito. Demais disso, sempre existirão pessoas, que por motivos racionais ou não, querem um julgamento, uma solução adjudicada para o conflito, ainda que isso represente um custo maior, e esse direito não lhes pode ser tolhido mediante pressões ilegítimas - o que o autor denomina de Gehirnwäsche, ou seja, lavagem cerebral - por parte do juiz. ${ }^{239}$

Na doutrina brasileira, BOTELHO DE MESQUITA assevera que a preferência do legislador pela conciliação é um fator de enfraquecimento do direito. $\mathrm{O}$ autor afirma que o indivíduo lesado vai a juízo com a justa expectativa, fundada no império do direito, de que o Estado lhe dará razão. Tal expectativa é frustrada no momento em que o juiz o induz a abrir mão de parte de um direito em favor de quem nenhum direito tem, abalando-se os alicerces da coesão social. Assim, o juiz que "força” a conciliação, torna desconfiados os homens simples e mais confiados os aventureiros. ${ }^{240}$

\footnotetext{
238 STADLER, Astrid. The multiples roles of Judges and Attorneys in Modern Civil Litigation, p. 74.

239 Aber der Vergleich darf das Urteil nicht aus dem Prozess hinausdrängen, denn die Rechtsgemeinschaft braucht es. Im Urteil bewährt sich das Recht, nur das Urteil kann es entwickeln und fortbilden. Das Grundgesetz spricht nur von Rechtsprechung, nicht von Schichtung (Art. 92 GG). Der Richter, gebunden an Gesetz und Recht (Art. 20 III GG), darf seine Autorität bei Vergleichsverhandlungen nicht missbrauchen, der Partei das Urteil zu verweigern. Es wird immer Menschen geben, vernünftige wie unwernünftige, die partout eine Urteil wollen und keinen Vergleich, auch wenn es sie den Prozess kostet. Ihnen darf der Richter den Anspruch auf das Urteil nicht durch eine Gehirnwäsche vereiteln. Traduzindo livremente - "Mas o acordo não deve poder retirar compulsoriamente o julgamento do âmbito do processo, pois a comunidade jurídica precisa dele. No julgamento feito por meio do processo é que garante a aplicação do Direito, sendo que apenas nele pode esta se desenvolver e se consolidar. A Constituição dispõe apenas sobre 'jurisprudência' (Art. 92). O juiz, vinculado à lei e ao Direito (Art. 20 III) não deve fazer um uso incorreto de sua autoridade, impondo às partes uma solução para seu conflito fora do processo. Sempre haverá pessoas que, racional ou irracionalmente, desejam que suas disputas sejam decididas judicialmente, e não por um acordo, mesmo que isto implique em arcar com custos mais altos. E o juiz não deve usar de qualquer lavagem cerebral para frustrar tais pretensões.” CHELLHAMMER. Zivilprozessreform und erste Instanz. In: Monatsschrift fur Deutsches Recht, 2001, apud MURRAY, Peter; STÜRNER, Rolf. German Civil Justice, p. 488-489.

${ }^{240}$ BOTELHO DE MESQUITA, José Ignácio. As novas tendências do direito processual: uma contribuição para o seu reexame. In: Tribunais, 2005. p. 290. Teses, Estudos e Pareceres de Processo Civil. v. 1. São Paulo: Revista dos
} 


\subsection{O MITO DA MENTALIDADE JAPONESA DE RESOLUÇÃO DE CONFLITOS DE FORMA NÃO ADJUDICADA}

A Restauração Meiji (Meiji Ishin) introduziu no Japão, no último quartel do século XIX, métodos de resolução de conflitos de bases ocidentais, rompendo com o até então vigente sistema Ritsuryô de orientação confuciana. ${ }^{241}$

O direito processual civil japonês foi então forjado tendo como molde a Zivilprozessordung alemã (a rigor, o Código de Processo Civil Japonês de 1891 não passa de uma tradução da ZPO), publicada pelo Reichstag em 1877, considerada na época o mais aperfeiçoado diploma processual existente. Sem prejuízo da adoção desta matriz germânica, foi também importado o modelo de conciliation préliminaire da França, com a forma de uma tentativa pré-processual de conciliação obrigatória (kankai). ${ }^{242}$

Apesar de ser questionável a satisfação dos jurisdicionados quanto ao uso da kankai, tal método apresentou elevado nível de eficiência. Conforme registros do Ministério da Justiça japonês, entre 1877 e 1885, apenas no ano de 1877 o percentual de acordos ficou abaixo dos $80 \%$, sendo que em 1885, este número ultrapassou o patamar de $90 \% .^{243}$

Já no século XX, sob a égide do Código de Processo Civil de 1891, o modelo de justiça conciliativa - que passou a ser denominado de chôtei - cresceu juntamente com os esforços de guerra do regime imperial. ${ }^{244}$ A necessidade de contenção de gastos em setores não considerados estratégicos, tal como a administração da justiça, e a existência de pouquíssimos letrados em Direito - que em última análise significou um fator determinante para o insucesso do modelo germânico de processo no Japão -, consagraram a conciliação como uma saída barata para a resolução de litígios entre particulares.

É importante notar que a tônica da chôtei não era fornecer uma justiça de melhor qualidade, mas sim resolver litígios privados de forma rápida, barata e

\footnotetext{
${ }^{241}$ SATO, Yasunobu. Cultural Conflict in Dispute Processing under Globalization: International Coopertation for Legal Aid in Asia. Asia-Pacific Economic Cooperation discussion paper n. 36. Disponível em: <http://www.gsid.nagoya-u.ac.jp/project/apec/outcomes/paper00/36/Sato.pdf>. Acesso em: 05 jul. 2009. p. 12.

${ }^{242}$ SATO, Yasunobu. Cultural Conflict in Dispute Processing under Globalization, p. 12.

243 SATO, Yasunobu. Cultural Conflict in Dispute Processing under Globalization, p. 13-14.

244 SATO, Yasunobu. Cultural Conflict in Dispute Processing under Globalization, p. 14-15.
} 
sem a necessidade de intervenção de profissionais com formação universitária, de modo que os escassos recursos humanos e materiais pudessem ser alocados em setores de maior relevância para as pretensões expansionistas do Império Japonês.

Em 1926 o Código de Processo Civil japonês foi alterado substancialmente para recepcionar o modelo processual adotado pela ZPO austríaca de 1895. ${ }^{245}$ Após a Segunda Guerra Mundial, com as reformas institucionais impostas pelos Estados Unidos, o Japão assistiu a um progressivo aumento de independência do Poder Judiciário, juntamente com o fortalecimento do caráter adversarial do processo, e a progressiva introdução de regras de cross-examination no âmbito probatório, assim a importação de diversos dispositivos das Rules of Civil Procedure. Já a tentativa de introduzir no Japão um modelo de juízes eleitos - típico dos sistemas de Common Law não teve êxito, tendo-se optado pelo recrutamento com base em critérios técnicos, seguindo-se a tradição da Europa Continental. ${ }^{246}$

Todavia, mesmo após estas profundas alterações no sistema judicial japonês promovidas pelos norte-americanos, a conciliação ainda foi tida como um dos principais meios de resolução de conflitos. Deveras, ao se analisarem as estatísticas judiciárias do Japão, logo se percebe que este país se encontra numa posição peculiar. Por exemplo, o número de juízes aumentou apenas 190\% entre 1890 e 1993, sendo que a população neste mesmo período triplicou; o número de processos em primeira instância quadruplicou; e a economia japonesa saltou de uma industrialização incipiente, para ocupar um lugar de destaque no cenário mundial. ${ }^{247}$ O número de juízes por 100.000 habitantes no Japão é de apenas 2, ao passo que na Alemanha, que serviu de modelo para o sistema processual civil japonês, este número é de $28 .{ }^{248}$ Traduzindo tais números em palavras, pode-se afirmar que o Japão é talvez um dos únicos exemplos no mundo onde o desenvolvimento econômico não foi acompanhado por uma explosão do número de processos. $^{249}$

245 ODA, Hiroshi. Japanese Law. 3. ed., New York: Oxford University, 2009. p. 17. É curioso notar a preocupação do legislador japonês da época em manter uma legislação processual de vanguarda. A Alemanha, vizinha à Áustria, com a qual compartilha não somente a língua, mas também um certo acervo cultural, somente viria a recepcionar em sua legislação processual os influxos da ZPO austríaca de 1895 em 1933, ou seja, 7 anos após o Japão.

246 SATO, Yasunobu. Cultural Conflict in Dispute Processing under Globalization, p. 15-16.

247 SATO, Yasunobu. Cultural Conflict in Dispute Processing under Globalization, p. 18.

248 DAKOLIAS, Maria. The Judicial Sector in Latin America and the Caribbean. Washington: World Bank Publications, 1996. p. 25, nota 106.

${ }^{249}$ Não se pode confundir, contudo, o aumento da litigiosidade com o aumento do número de processos judiciais. O aumento do número de litígios parece ser um fenômeno ínsito ao desenvolvimento econômico- 
A explicação desse fenômeno, entretanto, envolve certa polêmica. TAKEYOSHI KAWASHIMA, numa interpretação sociológica, sustenta que os japoneses ao colocarem em primeiro plano a necessidade de se manter a harmonia entre as pessoas, numa perspectiva de uma cultura fortemente influenciada pelos postulados da filosofia confuciana, acabariam por conferir pouco valor ao ideal ocidental de cumprimento estrito da lei. ${ }^{250}$ Assim, a conciliação melhor se adaptaria ao modo de pensar dos japoneses, o que explicaria a aversão ao meios adjudicados de resolução de conflitos e a preferência pelos meios autocompositivos.

Em sentido contrário, a tese desenvolvida por HALLEY, especialista norte-americano em estudos jurídicos asiáticos, ganhou certa notoriedade e adesão no meio acadêmico japonês. ${ }^{251}$ Segundo o autor, a visão do japonês como um alguém que reluta a buscar pela via judicial a efetivação de seus direitos, preferindo se valer de meios autocompositivos de modo a não quebrar a harmonia em suas relações pessoais, seria em grande parte um mito, sendo que a prevalência da conciliação deveria ser interpretada como um problema de acesso à justiça, e não como um reflexo de supostos traços culturais próprios do povo japonês. ${ }^{252}$

Na perspectiva de HALley, desde o Período Meiji, diversas barreiras processuais foram opostas pelo regime imperial para tornar a forma adjudicada de resolução de conflitos pouco interessante. Pesquisas de opinião realizadas no Japão na década de 1970 demonstram que 64\% dos japoneses estariam dispostos a ajuizar uma demanda para efetivar um direito não cumprido voluntariamente se a outra parte se recusasse a firmar um acordo. ${ }^{253}$ Nesta linha de raciocínio, os elevados níveis de conciliação estariam relacionados a uma conciliação “forçada” determinada por barreiras econômicas e processuais instituídas de forma deliberada pelo governo para evitar maiores gastos com a máquina judicial. ${ }^{254}$

industrial de um país, em razão da maior complexidade das novas relações sociais. Já o aumento do número de processos judiciais envolve outros fatores, tais como a facilidade de acesso à justiça, o uso de meios alternativos de resolução de conflitos e, em certa medida, os aspectos culturais. Essa distinção parece estar presente no discurso oficial do Ministério da Justiça do Japão na década de 1990, ao buscar uma reforma do sistema processual. ODA, Hiroshi. Japanese Law, p. 409.

${ }^{250}$ KAWASHIMA, Takeyoshi. Japanese Way of legal Thinking. International Journal of Law Libraries, v. 7, n. 1, 1979. p. 129.

${ }^{251}$ MIYAZAWA, Setsuo. Taking Kawashima Seriously: A review of Japanese Research on Japanese Legal Consciousness and Disputing Behavior. Law and Society Review, n. 219, 1987-1988. p. 222.

${ }^{252}$ HALEY, John Owen. The Myth of Reluctant Litigant. Journal of Japanese Studies, v. 4, n. 2, p. 359371, verão de 1978.

${ }^{253}$ HALEY, John Owen. The Myth of Reluctant Litigant, p. 368.

${ }^{254}$ HALEY, John Owen. The Myth of Reluctant Litigant, p. 371. 
Segundo MIYAZAWA, fatores como a dificuldade de se obter assistência de um advogado no Japão, dada a escassez de profissionais desta área ${ }^{255}$, e a falta de paridade de armas nos casos em que apenas uma das partes tem condições de contratar serviços advocatícios prestados de forma personalizada estimulam o uso de formas autocompositivas de resolução de conflitos. ${ }^{256}$

Deveras, como noticia KAWANO, a representação por advogado nas causas civis no Japão não é obrigatória. Assim, em 2005, de 133.006 novos processos, em apenas 52.963 ambas as partes estavam assistidas por advogado, em 47.679 apenas o autor tinha advogado, em 5.719 apenas o réu, e em 26.645 ambas as partes não tinham assistência profissional. ${ }^{257}$ Ora, tais números devem ser levados em consideração ao se analisarem os elevados índices de processos que terminam em acordo no Japão.

As observações de SHOZO OTA acerca da realidade judicial japonesa corroboram este entendimento. $\mathrm{O}$ alto custo do processo judicial, a complexidade do sistema e a demora na resolução adjudicada de resolução de conflitos desencorajam a procura pelo Poder Judiciário, sendo que esta situação é ainda agravada pelos desentendimentos entre o Judiciário e a ordem dos advogados, motivada pela pela defesa de interesses corporativos. ${ }^{258}$

Assim, ao se abandonar uma interpretação da realidade judicial japonesa a partir de uma visão romantizada do povo japonês como um grupo social particularmente virtuoso, capaz de resolver seus conflitos sem o auxílio de um juiz, tal como pretendia KAWASHIMA, surge para o pesquisador estrangeiro um interessante ponto de reflexão, notadamente sobre o discurso - muitas vezes oficial - que atribui à justiça conciliativa a função de reverter o quadro de morosidade e excesso de serviço do Poder Judiciário: será que o que se busca com o estímulo à conciliação é uma justiça mais rápida e adequada aos anseios dos jurisdicionados ou uma justiça mais barata tout court?

\footnotetext{
255 Segundo dados citados por SHOZO OTA, existiam 18.197 advogados no Japão em $1^{\circ}$ de agosto de 2001, o que importava em aproximadamente 1 advogado para cada 7 mil habitantes. OTA, Shozo. Reform of Civil Procedure in Japan. American Journal of Comparative Law, n. 49, 2001. p. 564. No Brasil, segundo dados do Conselho Federal da OAB divulgados em 2008, existiam 571.360 advogados, o que representa 1 advogado para cada grupo de 322 habitantes.

${ }^{256}$ MIYAZAWA, Setsuo. Taking Kawashima Seriously, p. 234-235.

257 Relatório japonês apresentado por Masanori Kawano, da Universidade de Nagoya, ao painel Novas Tendências nos Procedimentos Preliminares do XIII Congresso Mundial de Direito Processual (Brasil-2007) apud ANDREWS, Neil. The pre-action-phase - General Report - Common Law, p. 204, nota 14.

${ }^{258}$ OTA, Shozo. Reform of Civil Procedure in Japan, p. 565.
} 


\subsection{PROJETO DE LEI QUE ALTERA A REDAÇÃO DO ARTIGO 331 DO CPC - PLC 94/2002 - ELABORADO PELO IBDP}

O Projeto de Lei da Câmara 94 de 2002 tem como objetivo institucionalizar e disciplinar a mediação como método de prevenção e solução consensual de conflitos na esfera civil. O projeto foi apresentado pelo Senador Pedro Simon, tendo sido elaborado pelo IBDP (Instituto Brasileiro de Direito Processual), em substituição ao projeto originário de autoria da Deputada Federal Zulaiê Cobra (PL 4827). Entre as inovações propostas, dois dispositivos interessam particularmente ao tema ora tratado.

E primeiro lugar, vale citar o artigo 43 do referido projeto, que já foi aprovado pelo Senado Federal, mas aguarda deliberação da Câmara de Deputados desde 2006. Tal dispositivo propõe nova alteração na redação do artigo 331 do CPC, nos seguintes termos:

\begin{tabular}{|c|c|}
\hline Redação Atual & Redação proposta pela PLC 94/2002 \\
\hline $\begin{array}{l}\text { Art. 331. Se não ocorrer qualquer das } \\
\text { hipóteses previstas nas seções precedentes, e } \\
\text { versar a causa sobre direitos que admitam } \\
\text { transação, o juiz designará audiência } \\
\text { preliminar, a realizar-se no prazo de } 30 \\
\text { (trinta) dias, para a qual serão as partes } \\
\text { intimadas a comparecer, podendo fazer-se } \\
\text { representar por procurador ou preposto, } \\
\text { compoderes para transigir. }\end{array}$ & $\begin{array}{l}\text { Art. 331. Se não se verificar qualquer das } \\
\text { hipóteses previstas nas seções precedentes, o } \\
\text { juiz designará audiência preliminar, a } \\
\text { realizar-se no prazo máximo de trinta dias, } \\
\text { para qual serão as partes intimadas a } \\
\text { comparecer, podendo fazer-se representar } \\
\text { por procurador ou preposto, com poderes } \\
\text { para transigir. }\end{array}$ \\
\hline Sem correspondente. & $\begin{array}{l}\S 1^{\circ} \text { Na audiência preliminar, o juiz ouvirá as } \\
\text { partes sobre os motivos e fundamentos da } \\
\text { demanda e tentará a conciliação, mesmo } \\
\text { tendo sido realizada a tentativa de mediação } \\
\text { prévia ou incidental. }\end{array}$ \\
\hline
\end{tabular}




\begin{tabular}{|c|c|}
\hline Redação Atual & Redação proposta pela PLC 94/2002 \\
\hline Sem correspondente. & $\begin{array}{l}\S 2^{\circ} \text { A lei local poderá instituir juiz } \\
\text { conciliador ou recrutar conciliadores para } \\
\text { auxiliarem o juiz da causa na tentativa de } \\
\text { solução amigável dos conflitos. }\end{array}$ \\
\hline Sem correspondente. & $\begin{array}{l}\S 3^{\circ} \text { Segundo as peculiaridades do caso, } \\
\text { outras formas adequadas de solução do } \\
\text { conflito poderão ser sugeridas pelo juiz, } \\
\text { inclusive a arbitragem, na forma da lei, a } \\
\text { mediação e a avaliação neutra de terceiro. }\end{array}$ \\
\hline Sem correspondente. & $\begin{array}{l}\S 4^{\circ} \text { A avaliação neutra de terceiro, a ser } \\
\text { obtida no prazo a ser fixado pelo juiz, é } \\
\text { sigilosa, inclusive para este, e não vinculante } \\
\text { para as partes, sendo sua finalidade } \\
\text { exclusiva a de orientá-las na tentativa de } \\
\text { composição amigável do conflito. }\end{array}$ \\
\hline $\begin{array}{l}\S 1^{\circ} \text { Obtida a conciliação, será reduzida a } \\
\text { termo e homologada por sentença. }\end{array}$ & $\begin{array}{l}\S 5^{\circ} \text { Obtido o acordo, será reduzido a termo e } \\
\text { homologado pelo juiz. }\end{array}$ \\
\hline $\begin{array}{l}\S 2^{\circ} \text { Se, por qualquer motivo, não for obtida a } \\
\text { conciliação, o juiz fixará os pontos } \\
\text { controvertidos, decidirá as questões } \\
\text { processuais pendentes e determinará as } \\
\text { provas a serem produzidas, designando } \\
\text { audiência de instrução e julgamento, se } \\
\text { necessário. }\end{array}$ & $\begin{array}{l}\S 6^{\circ} \text { Se, por qualquer motivo, a conciliação } \\
\text { não produzir resultados e não for adotado } \\
\text { outro meio de solução do conflito, o juiz, na } \\
\text { mesma audiência, fixará os pontos } \\
\text { controvertidos, decidirá as questões } \\
\text { processuais pendentes e determinará as } \\
\text { provas a serem produzidas, designando } \\
\text { audiência de instrução e julgamento, se } \\
\text { necessário. }\end{array}$ \\
\hline $\begin{array}{l}\S 3^{\circ} \text { Se o direito em litígio não admitir } \\
\text { transação, ou se as circunstâncias da causa } \\
\text { evidenciarem ser improvável sua obtenção, o } \\
\text { juiz poderá, desde logo, sanear o processo e } \\
\text { ordenar a produção da prova, nos termos do } \\
\S 2^{\circ} \text {. }\end{array}$ & Sem correspondente. \\
\hline
\end{tabular}


Outro ponto de interesse é a inserção do artigo 331-A, com a seguinte redação: art. 331-A. Em qualquer tempo e grau de jurisdição, poderá o juiz ou tribunal adotar, no que couber, as providências previstas no artigo anterior.

\subsection{ANÁLISE DO PROJETO DE LEI DA CÂMARA 94/2002 NO QUE SE REFERE À NOVA REDAÇÃO DO ARTIGO 331 DO CPC}

O PLC 94/2002 propõe nova alteração ao artigo 331 do CPC, para determinar a volta ao regime obrigatório da audiência preliminar. Conforme analisado e exposto em tópico acima, a questão da obrigatoriedade ou facultatividade da audiência preliminar não é algo que pode ser discutido em abstrato, mas apenas tendo em vista a realidade de cada localidade.

A experiência brasileira recente, com o regime obrigatório instituído pela Lei Federal n. 8.952 de 1994, e o retorno ao regime facultativo com a Lei Federal n. 10.444 de 2002, demonstrou que sem prévio treinamento e preparação necessária dos profissionais do direito, a audiência preliminar não é capaz de produzir os efeitos desejados pelo legislador.

A inserção do artigo 331-A ao CPC não traz muita novidade ao sistema. Tentar conciliar as partes, sugerir outros meios de resolução de conflitos, e homologar um acordo são condutas que o juiz poderia tomar com ou sem previsão legal. Demais disso, o dever de conciliar já está expresso no artigo 125, inciso IV, do CPC, sendo que a sua repetição pelo artigo 331-A seria desnecessária. Deveras, vale lembrar que a inserção do §278 (1) na ZPO alemã com um mandamento similar, em nada alterou a realidade forense.

A supressão da referência aos direitos disponíveis é salutar. A disponibilidade ou não do direito nunca foi um critério válido para a designação ou não da audiência preliminar, seja porque o escopo deste ato não se esgota na tentativa de conciliação, seja porque mesmo versando a demanda sobre direitos indisponíveis, não se pode excluir por completo certa margem de negociação entre as partes. Por exemplo, nada 
impede que as partes numa ação de anulação de casamento aceitem sua conversão numa separação consensual, a ser homologada pelo juízo. ${ }^{259}$

O que não parece adequado é negar ao juiz a possibilidade de designar ou não uma audiência preliminar, sacrificando de certa forma uma desejada flexibilidade procedimental e engessando o procedimento.

O objetivo primacial da PLC 94/2002, qual seja, promover a chamada justiça conciliativa, pode muito bem ser alcançado sem a necessidade de lei alguma. Exemplo disso é a iniciativa do Tribunal de Justiça do Estado de São Paulo em autorizar a criação de setores de conciliação em todas as comarcas do Estado, pelo Provimento n. 893/2004-CSM, parcialmente modificado pelo Provimento n. 953/2005CSM.

Segundo dados Controle de Movimento Judiciário da Corregedoria Geral de Justiça do Estado de São Paulo, coletados entre janeiro de 2006 e janeiro de 2007 e relativos a 76 comarcas que instalaram setores de conciliação com base no Provimento n. 953/2005-CSM, de 76.179 processos encaminhados, foram realizadas 37.953 sessões de conciliação, resultando em 17.001 acordos homologados. Em termos porcentuais, 22\% dos processos encaminhados voltaram com acordos para serem homologados, e, quase 50\% das sessões surtiram resultados. ${ }^{260}$

Ocorre que medidas exemplares como esta demandam planejamento, investimento, infraestrutura e treinamento de pessoal. Legislar, por outro lado, como bem observa OBERHAMMER, é barato e gera grande visibilidade política, porém, conforme tem demonstrado experiência histórica, tende a não surtir grandes mudanças. $^{261}$

\footnotetext{
${ }^{259}$ WAMBIER, Luiz Rodrigues. A Nova Audiência Preliminar. Revista de Processo, São Paulo, Revista dos Tribunais, n. 80, out./dez., 1995. p. 34.

${ }^{260}$ Dados citados por POZZEBON e ROMANO. POZZEBON, Gustavo R. Chaim; ROMANO, Michel Betenjane. O papel do Ministério Público na Pacificação de Conflitos. In: GRINOVER, Ada Pellegrini; WATANABE, Kazuo; LAGRASTA NETO, Caetano (Coord.). Mediação e Gerenciamento do Processo Revolução na Prestação Jurisdicional. São Paulo: Atlas, 2008. p. 42.

${ }^{261}$ OBRHAMMER, Paul. Speeding up Civil Litigation in Austria: past and present instruments. In: RHEE, C. H. van (Org.). The Law's Delay: Essays on Undue Delay in Civil Litigation. Intersentia, 2004. p. 218.
} 


\subsection{AUDIÊNCIA DE CONCILIAÇÃO NO PROJETO DE LEI DO SENADO 166/2010 (PROJETO DO NOVO CPC)}

O Projeto de Lei do Senado 166/2010 trata, em seu artigo 333, da audiência de conciliação. O procedimento adotado pelo PLS 166/2010 representa um retrocesso em relação ao atual CPC, porquanto não prevê expressamente a possibilidade do saneamento em audiência, quando a tentativa de conciliação é promovida pelo próprio juiz.

A audiência do artigo 331 do CPC possui um escopo mais amplo do que aquela do artigo 333 do PLS 166/2010. Isso porque, na sistemática atual, quando frustrada a conciliação, pode o juiz desde então realizar o saneamento do processo e organizar a atividade instrutória (art. 331, §1 CPC). Já o artigo 333 do PLS 166/2010, talvez apostando no sucesso da atuação dos conciliadores e mediadores, não prevê expressamente a possibilidade de saneamento do processo em audiência - saneamento oral - quando esta for presidida pelo próprio juiz e não tiver sido obtida a conciliação.

O PLS 166/2010 retorna à sistemática anterior à Lei n. 8.952/94, e prestigia em seu artigo 354 ao modelo escrito de saneamento do processo. Ora, esse engessamento do procedimento não merece elogios, pois incumbe ao juiz, considerando as peculiaridades de cada situação concreta, a opção entre o modelo escrito e o modelo oral de saneamento.

\subsection{O CONCILIADOR E O MEDIADOR NO PROJETO DE LEI DO SENADO 166/2010 (PROJETO DO NOVO CPC)}

O Projeto de Lei do Senado 166/2010 inova ao disciplinar a atuação dos conciliadores e mediadores, no capítulo dos auxiliares da Justiça.

É claro que a referência ao conciliador já existe na legislação atual. É o que ocorre no procedimento comum sumário (art. 277, §1 CPC) e nos Juizados Especiais Cíveis (art. $7^{\circ}$ da Lei n. 9.099/95). A inovação substancial encontra-se na disciplina da seleção, registro, nomeação, remuneração e deveres daqueles que exercem tal função. 
O artigo 134 do PLS 166/2010 dispõe que cada tribunal poderá propor a criação, por lei de organização judiciária, de um Setor de Mediação e Conciliação. O dispositivo, contudo, tal como redigido, poderá ensejar discussões estéreis sobre a legalidade dos já existentes setores de conciliação instalados por diversos Estados da federação, criados por atos normativos dos próprios tribunais, à margem de qualquer previsão legal.

De um lado, poderia ser sustentado que a criação de um setor de conciliação por ato normativo do próprio tribunal estaria eivada de inconstitucionalidade, pois haveria violação do artigo 24, inciso XI, da Constituição da República, que trata da competência concorrente entre União e Estados para legislar sobre procedimentos em matéria processual. Deveras, tal entendimento seria corroborado pela referência à lei de organização judiciária na redação do artigo 134 do PLS 166/2010.

De outro lado, poderia ser afirmado que a criação de um setor de conciliação independe de lei, pois não implica modificação alguma no procedimento, não havendo violação ao artigo 24, inciso XI, da Constituição da República. Deveras, tal entendimento é o mais adequado, pois melhor se coaduna com o princípio republicano do autogoverno dos tribunais. Ora, o artigo 96, inciso I, alínea b, da Constituição da República determina que compete privativamente aos tribunais organizar os seus serviços auxiliares e os serviços dos juízos que lhes forem vinculados.

Ainda, há de se considerar que o referido artigo 134 do PLS 166/2010 ao dispor que compete aos tribunais propor a criação de um setor de conciliação e mediação por lei, extrapola os limites da legislação infraconstitucional. Somente por emenda constitucional poderia ser criada uma nova hipótese de iniciativa legislativa reservada.

Demais disso, sustentar que somente a lei em sentido formal poderia criar um setor de conciliação traria consequências dramáticas na prática. Em diversos Estados, inclusive em São Paulo, o setor de conciliação funciona sem que haja qualquer previsão legal na lei de organização judiciária.

Assim seria mais adequado que o dispositivo fosse redigido da seguinte maneira: art. 134. Cada tribunal pode criar um setor de conciliação e mediação. 
Outro dispositivo que merece críticas é o artigo 137, §1º do PLS 166/2010, que exige a inscrição na OAB para o exercício da função de conciliador e mediador.

O exercício da função de conciliador ou de mediador não exige formação jurídica. Desde que devidamente instruída por meio de um curso de capacitação, qualquer pessoa pode desempenhar tais funções. O conciliador e o mediador não julgam pedidos, não resolvem questões técnico-jurídicas, nem substituem o juiz. Não é dado ao conciliador e ao mediador expor a sua opinião sobre os aspectos jurídicos do litígio. Deveras, em determinadas situações, profissionais de outras áreas, tal como a Psicologia, mostram-se muito mais hábeis em pacificar certos conflitos que o advogado.

Não se pode perder de vista que extrajudicialmente qualquer pessoa pode exercer a função de conciliador ou mediador de um conflito, independentemente de qualquer qualificação profissional, sem que tal fato importe ilícito civil ou penal. Deveras, não se trata de atividade exclusiva de uma profissão regulamentada.

É claro que a exigência de um curso de capacitação para aqueles que pretendem exercer tal atividade no âmbito do Poder Judiciário é salutar, pois importa padrões mínimos de qualidade na prestação de um serviço público. Mas estabelecer a inscrição na OAB como requisito obrigatório para o exercício desta atividade é criar uma injustificada reserva de mercado.

\subsection{A CONCENTRAÇÃO PROCEDIMENTAL NA FASE PRELIMINAR: UMA QUESTÃO DE REDUÇÃO DE CUSTOS}

Quando se fala em concentração procedimental na fase preliminar logo se pensa no modelo de Stuttgart. Todavia, é preciso ter em mente que as chamadas reformas de Stuttgart da década de 1970, que buscaram concentrar a fase preliminar em preferencialmente uma única audiência preliminar, foram pensadas numa época em que os julgamentos nas Landgerichte ${ }^{262}$ eram em sua maioria realizados de forma colegiada. A

262 A Landgericht, presente nas 116 principais cidades da Alemanha, é a espinha dorsal do sistema judicial alemão, sendo que foi tendo em vista esse órgão que a própria ZPO foi pensada. Neste país, o Poder Judiciário é dividido em 5 ramos: trabalhista, administrativo, previdenciário, tributário, e competência 
necessidade de reunir o órgão colegiado para uma séria de audiências preliminares acerca de um único litígio causava preocupação tendo-se em vista o crescente número de processos. $^{263}$

Neste aspecto, é interessante destacar que paralelamente ao ideal de concentração da fase preliminar em uma única audiência, buscou-se paulatinamente reduzir as hipóteses de julgamento colegiado em primeiro grau nas Landgerichte. Em 1974, abriu-se oportunidade para as partes optarem pelo juiz singular, em substituição ao órgão colegiado, não apenas em relação à fase preliminar, mas em relação a todo o procedimento. A partir de 1993 foi ampliada a competência do juiz singular, cabendo a este decidir sobre a conveniência do julgamento de forma colegiada. Por fim, desde $1^{\circ}$ de janeiro de 2002, o julgamento pelo juiz singular passou a ser a regra geral, ficando o julgamento pelo órgão colegiado reservado apenas para determinadas matérias (e.g. responsabilidade civil de profissionais liberais, litígios decorrentes de construção civil, relações bancárias, etc.), para os casos em que o juiz singular competente para o caso estiver em estágio probatório (Richter auf Probe), ou ainda nos casos em que o juiz singular considerar que o caso envolve questões de fato ou de direito particularmente difíceis de serem resolvidas (die Sache besondere Schwierigkeit tatsächlicher oder rechtlicher Art aufweist), ou que a questão de direito expressa um significado fundamental (die Rechtssache grundsätzliche Bedeutung hat). ${ }^{264}$

O mesmo movimento no sentido abandonar o julgamento colegiado em primeiro grau pode ser observado na Áustria. Originalmente, em 1895, tanto a ZPO quanto a Jurisdiktionsnorm apontavam para um julgamento colegiado nas Landesgerichte. Atualmente, somente demandas que envolvam quantias superiores a $€$ 50,000 (cinquenta mil euros), podem ser julgadas por um colegiado de três juízes em

residual (ordentliche Gerichte). Os órgãos judiciais que compõem ordentliche Gerichte são as Amtsgerichte, as Landgerichte, as Oberlandesgerichte e a Bundesgerichthof. As Amtsgerichte, presentes em 693 localidades na Alemanha, e com competência, em matéria civil, para os litígios em que o valor discutido não ultrapassa 5 mil Euros, ou, independentemente do valor, em razão da matéria, nos casos de família, sucessões, locação residencial, entre outros. A Landgericht, além de servir como grau recursal em casos específicos julgados pelas Amtsgerichte, serve de primeiro grau para a generalidade dos litígios civis. As Oberlandesgerichte atuam como cortes recursais ordinárias, ao passo que a Bundesgerichthof, com sede em Karlsruhe, é a Corte Suprema nos casos que não são de competência das justiças especializadas. Fora da jurisdição ordinária, e acima de toda essa estrutura, se encontra a Bundesverfassungsgericht - a Corte Constitucional Alemã -, que pode ser acessada pelos particulares, em casos excepcionais, pela via recursal (Verfassungsbeschwerde). MURRAY, Peter; STÜRNER, Rolf. German Civil Justice, p. 37-65.

${ }^{263}$ MURRAY, Peter; STÜRNER, Rolf. German Civil Justice, p. 52.

${ }^{264}$ MURRAY, Peter; STÜRNER, Rolf. German Civil Justice, p. 51-53 e 212-213. 
primeiro grau, se assim requerer alguma das partes, o que representa menos de $1 \%$ dos julgamentos. $^{265}$

O que existe de comum entre a prevalência da condução do processo pelo juiz singular, tanto na fase preliminar como em todo o restante do procedimento, e o ideal de concentração das atividades do juiz na fase preliminar em uma única audiência é a redução de custos.

${ }^{265}$ KLICKA, Thomas; RECHBERGER, Walter. Accelerating Civil Litigation in Austria in the Twentieth Century, p. 235. 


\section{ORALIDADE NA AUDIÊNCIA DE INSTRUÇÃO}

Na Alemanha, ao contrário do que ocorre com a audiência preliminar, na qual se adotou o regime facultativo, a audiência principal é em regra obrigatória. É o que decorre do $\S 128$ da ZPO. No entanto, é preciso interpretar este dispositivo com cautela, dada a largueza das exceções a essa regra.

Somente decisões que resultem em julgamento (Urteile) exigem a prévia realização de uma audiência. Assim, conforme afirmam STÜRNER e MURRAY, Isso significa que decisões que resultam em simples ordens (Beschlüsse) ou ordens processuais (Verfügungen) não requerem um procedimento oral, o que permite um procedimento eminentemente escrito na Mahnverfahren - que, em grossas linhas, corresponde à ação monitória brasileira - e exerce um importante papel no cotidiano forense daquele país. ${ }^{266}$

Demais disso, o $§ 128$ (2) estabelece que, havendo consentimento das partes, o juiz pode decidir sem prévio procedimento oral, o que reforça a ideia de que a maior ou menor dose de oralidade no procedimento seria, sobretudo, uma questão de conveniência, não envolvendo garantias processuais. Ainda, caso ambas as partes deixem de comparecer à audiência designada, o juiz é autorizado a julgar desde logo com base no estado dos autos (Entscheidung nach Lage der Akten). ${ }^{267}$

Trata-se da mesma lógica empregada no artigo 330, inciso I, do Código de Processo Civil brasileiro. A possibilidade de julgamento antecipado da demanda reforça a tese de que a oralidade não constitui uma garantia fundamental das partes, tanto que pode ser suprimida de acordo com a conveniência da instrução.

No que tange ao gerenciamento de processos na audiência de instrução, mostra-se de importância cardeal o estudo dos autos pelo magistrado antes do ato. Isso porque o juiz que não teve tempo de estudar o processo antes da audiência não é capaz de avaliar a pertinência das perguntas formuladas pelos advogados das partes, alongando a audiência para além do necessário.

\footnotetext{
${ }^{266}$ MURRAY, Peter; STÜRNER, Rolf. German Civil Justice, p. 185.

267 STÜRNER e MURRAY narram que esses dispositivos foram recebidos sem grandes entusiasmos pela doutrina alemã. MURRAY, Peter; STÜRNER, Rolf. German Civil Justice, p. 186.
} 
Além disso, o prévio estudo dos autos permite ao juiz sinalizar às partes - duty to give hints and feedbacks, na feliz expressão da doutrina anglo-saxã -, no curso da audiência, seu convencimento acerca das provas já produzidas.

Conforme já sustentado em tópico acima, sob a perspectiva da cooperação entre juiz e partes, não existe óbice a que o juiz lhes adiante seu entendimento sobre a prova já produzida. O juiz não é um oráculo e a sentença deve ser o mais previsível possível para os advogados.

Assim, pode o juiz numa audiência de instrução, adiantar aos advogados que, por exemplo, está satisfeito com a demonstração da culpa numa demanda envolvendo responsabilidade civil, possuindo, todavia, dúvidas acerca da prova da extensão do dano alegado.

Isso permite aos advogados não apenas direcionar melhor seus pedidos de produção de prova, como dá às partes melhores perspectivas para discutirem um acordo. Ora, a audiência deve ser menos palco de discursos inflamados e mais um espaço para um diálogo natural entre juiz e partes.

Outra vantagem do contato direto entre juiz e partes em audiência de instrução refere-se à visibilidade e à transparência da justiça. É claro que não se pretende chegar ao extremo de afirmar que "a justiça precisa ser vista": justice must be seen in order to be done. Mas, sobretudo em casos envolvendo pessoas humildes, o mero fato de lhes serem franqueadas a possibilidade estar na sala de audiência na presença de um juiz já é um fator que resgata algum senso de dignidade e cidadania.

É certo que isso é um fator cultural que em boa medida se perde em grandes centros urbanos. Mas em pequenas localidades do interior a imagem institucional do Poder Judiciário se confunde sobremaneira aos olhos da população com a própria pessoa do juiz. Neste cenário, a audiência representa ao jurisdicionado uma reafirmação de transparência no julgamento de sua demanda. 


\subsection{FORMAS DE PRODUÇÃO DA PROVA TESTEMUNHAL: OS DEPOIMENTOS ESCRITOS, OS DEPOIMENTOS GRAVADOS E A VIDEOCONFERÊNCIA}

\subsubsection{ADMISSÃO DOS AFFIDAVITS COMO PROVA}

Atualmente tem se levantado a possibilidade de, em determinadas hipóteses, a prova testemunhal produzida em juízo ser substituída por declarações escritas (affidavits) ou gravadas da testemunha, importando em redução de custos e tempo.

BENTHAM afirmava que a força probante da prova testemunhal poderia ser diminuída em razão da fonte (falta de qualidade moral ou intelectual da testemunha) ou da forma (não observância de regras técnicas relativas à prova testemunhal, tais como a publicidade, a não sujeição ao crime de falso testemunho, a vedação de respostas premeditadas, etc.). Neste último caso, o autor exemplifica com o testemunho por affidavit. ${ }^{268}$

Na seara do processo penal tem se tornado comum a utilização de declarações escritas como forma de se evitar a necessidade de colher em audiência os depoimentos das chamadas “testemunhas de antecedentes”, ou seja, de alguém que não irá depor sobre os fatos objeto do processo, mas apenas sobre a vida pregressa do réu.

Na doutrina brasileira, EDUARDO CAMBI admite as declarações escritas provenientes de terceiros como provas atípicas, ressalvando, no entanto, que o seu valor probatório é menor, porquanto a outra parte não participou do contraditório. Sendo possível, assevera o autor, essa prova deve ser repetida em juízo, adquirindo o caráter de prova testemunhal, caso contrário, estas declarações são admitidas como prova documental com eficácia probatória de caráter indiciário. ${ }^{269}$

No mesmo sentido, MOACYR AMARAL SANTOS já sustentava tal entendimento. Aduz o autor que o que a lei veda é que a testemunha preste depoimento por escrito; entretanto, não se tratando de testemunha, mas sim de pessoa que não foi

${ }^{268}$ BENTHAM, Jeremy. Traité des Preuves Judiciaires. Tradução e compilação dos manuscritos por Étienne Dummont. Paris: Bossange Frères, 1823. Livro I, Cap. XVI, p. 86.

${ }^{269}$ CAMBI, Eduardo. A Prova Civil: admissibilidade e relevância. São Paulo: Revista dos Tribunais, 2006. p. 48. 
arrolada como tal, ou ainda, de testemunha que deixou de comparecer à audiência, nenhum impedimento haveria para que suas declarações escritas fossem juntadas aos autos como documento.

Na Itália, mesmo antes da Legge 69 de 18 de junho de 2009, parte da doutrina já acenava para a admissão da chamada testimonianza scritta, admitindo-a, contudo, com uma força probatória menor em relação à prova testemunhal oral.

Deveras, esta assertiva, sem resvalar em qualquer consideração de prova tarifada, reflete apenas certo senso comum, ou seja, uma declaração de viva voz é sempre mais fidedigna do que aquela prestada por escrito ou por intermédio de terceira pessoa. Tanto é assim que se encontra recolhido no Digesto um rescrito de Adriano neste sentido (D. 22.5.3.4 Alia est auctoritas praesentium testium, alia testimoniorum quae recitari solent: tecum ergo delibera, ut, si retinere eos velis, des eis impendia).

O Modelo de Stuttgart, como medida de racionalização das atividades do tribunal, não recomenda a produção de prova testemunhal nos casos em que o ponto a ser esclarecido é de menor importância e complexidade, sendo suficiente a mera colheita de uma declaração escrita da testemunha sobre os pontos questionados. ${ }^{270}$

Outra prática altamente desaconselhada pelo Modelo de Stuttgart é a oitiva de testemunhas que moram em localidades distantes do juízo por meio da delegação da colheita da prova testemunhal para outros órgãos judiciais, sistema que no Brasil se dá por via das cartas precatórias. Nestas hipóteses, testemunhos escritos podem ser admitidos no lugar da prova testemunhal colhida por outros órgãos judiciais. ${ }^{271}$

Do ponto de vista do magistrado, a colheita de prova testemunhal por meio de carta precatória apresenta uma relação de custo e benefício questionável. Isso porque, conforme já afirmado neste trabalho, o controle da pertinência das questões formuladas pelos advogados pressupõe o prévio estudo dos autos pelo juiz. Deveras, o juiz que estuda os autos do processo antes da audiência de instrução tem condições de indeferir perguntas impertinentes, de modo que o tempo de duração do ato reduz sensivelmente. Todavia, esse tempo economizado na duração da audiência ainda é inferior ao tempo que o juiz precisa para estudar o caso, de modo que tal economia de tempo somente trará frutos ao magistrado em termos de celeridade por ocasião da prolação da sentença, pois, já tendo

270 BENDER, Rolf. The Stuttgart Model, p. 450.

271 BENDER, Rolf. The Stuttgart Model, p. 450-451. 
estudado os autos anteriormente, o tempo de conclusão para a sentença também será reduzido de forma sensível.

Isso significa que em termos de otimização do tempo, para o juiz não vale a pena estudar o caso antes da oitiva de uma testemunha na qualidade de juízo deprecado, porquanto, como não irá prolatar sentença sobre aquele caso, o prévio estudo do feito a ser instruído não traz ao juiz maior ganho em celeridade.

Ora, a ineficiência do sistema de delegação da oitiva de testemunhas de fora do juízo abre portas para três alternativas: a admissão de testemunhos escritos, a admissão da produção da prova testemunhal sem intervenção judicial, e o apelo aos mecanismos audiovisuais.

Na Itália, a recente reforma promovida pela Legge 69 de 18 de junho de 2009 introduziu no processo civil a chamada testimonianza scritta. ${ }^{272}$ Em linhas gerais, permitiu-se ao juiz, havendo concordância das partes, e levando-se em consideração a natureza da causa e outras circunstâncias, colher os depoimentos das testemunhas por escrito, dispensando-se a oitiva destas de viva voz em audiência, sem prejuízo de posterior oitiva pessoal, caso o juiz venha a entender que tal ato seja necessário. O contraditório fica preservado com a possibilidade de as partes formularem quesitos a serem respondidos pela testemunha, sendo demais disso aplicáveis as sanções penais referentes ao falso testemunho, bem como as escusas pessoais das testemunhas para não depor.

${ }^{272}$ A referida lei introduziu no Codice di Procedura Civile o seguinte dispositivo: art. 257-bis. Il giudice, su accordo delle parti, tenuto conto della natura della causa e di ogni altra circostanza, può disporre di assumere la deposizione chiedendo al testimone, anche nelle ipotesi di cui all'articolo 203, di fornire, per iscritto e nel termine fissato, le risposte ai quesiti sui quali deve essere interrogato.

Il giudice, con il provvedimento di cui al primo comma, dispone che la parte che ha richiesto l'assunzione predisponga il modello di testimonianza in conformità agli articoli ammessi e lo faccia notificare al testimone.

Il testimone rende la deposizione compilando il modello di testimonianza in ogni sua parte, con risposta separata a ciascuno dei quesiti, e precisa quali sono quelli cui non è in grado di rispondere, indicandone la ragione.

Il testimone sottoscrive la deposizione apponendo la propria firma autenticata su ciascuna delle facciate del foglio di testimonianza, che spedisce in busta chiusa con plico raccomandato o consegna alla cancelleria del giudice.

Quando il testimone si avvale della facoltà d'astensione di cui all'articolo 249, ha l'obbligo di compilare il modello di testimonianza, indicando le complete generalità e i motivi di astensione.

Quando il testimone non spedisce o non consegna le risposte scritte nel termine stabilito, il giudice può condannarlo alla pena pecuniaria di cui all'articolo 255, primo comma.

Quando la testimonianza ha ad oggetto documenti di spesa già depositati dalle parti, essa può essere resa mediante dichiarazione sottoscritta dal testimone e trasmessa al difensore della parte nel cui interesse la prova è stata ammessa, senza il ricorso al modello di cui al secondo comma.

Il giudice, esaminate le risposte o le dichiarazioni, può sempre disporre che il testimone sia chiamato a deporre davanti a lui o davanti al giudice delegato. 
É relevante notar que a lei italiana não faz nenhuma ressalva à utilização deste dispositivo para causas envolvendo direitos indisponíveis. Conforme noticia GIAMPIERO BALENA, a limitação ao uso do depoimento escrito às causas que tinham por objeto direitos disponíveis, presente num inciso do projeto de lei, não constou da redação final do artigo 257 - bis, porquanto tal limitação representaria uma injustificada desconfiança por parte do legislador quanto à idoneidade desta forma de colheita da prova testemunhal. ${ }^{273}$

A crítica que se tem feito é quanto ao restrito âmbito de aplicação desse dispositivo. A exigência de concordância de ambas as partes para a utilização dessa forma de colheita da prova testemunhal poderá tornar a aplicação do artigo 257 - bis do Codice di Procedura Civile um tanto esporádica, limitada aos casos em que as partes sabem de antemão que a testemunha nada de relevante tem a dizer, ou aos casos versando sobre direitos indisponíveis e com réu revel. ${ }^{274}$

Demais disso, é de se esperar que o novo artigo 257 - bis do Codice di Procedura Civile desestimule o uso de declarações unilaterais de terceiro como prova atípica, conforme prediz ANTONIO BRIGUGLIO. ${ }^{275}$ Havendo uma forma legal para a colheita de declarações escritas, não haveria razão para se admitir o uso de declarações fora dos moldes legais como prova atípica, dada a existência, neste caso, de prejuízo ao contraditório.

Outra observação interessante é a de que o legislador italiano perdeu uma boa oportunidade para difundir o uso de meios audiovisuais de gravação na documentação de atos processuais. Segundo noticia BALENA, tem se tornado comum em alguns ofícios judiciais italianos, a despeito da inexistência de permissivo legal expresso, a prática de advogados de ambas as partes, em conjunto, gravarem em vídeo as perguntas às testemunhas, submetendo a gravação ao juiz como prova, sem prejuízo da possibilidade de o juiz convocar estas testemunhas para eventuais esclarecimentos que lhe pareçam oportunos. ${ }^{276}$ É verdade que esta prática fica de certa forma legitimada pelo artigo 257 bis, pois se as partes podem realizar tal procedimento por escrito, não haveria razão para

\footnotetext{
273 BALENA, Giampiero. La nuova pseudo-riforma della giustizia civile. 29 jul. 2009. Disponível em: <www.judicium.it>. Acesso em: 30 jul. 2009. p. 29.

${ }^{274}$ BALENA, Giampiero. La nuova pseudo-riforma della giustizia civile, p. 29-30. BRIGUGLIO, Antonio. Le novità sul processo ordinario di cognizione nell'ultima, ennesima riforma in materia di giustizia civile. Disponível em: <www.judicium.it>. Acesso em: 30 jul. 2009.

${ }^{275}$ BRIGUGLIO, Antonio. Le novità sul processo ordinario di cognizione nell'ultima, ennesima riforma in materia di giustizia civile.

${ }^{276}$ BALENA, Giampiero. La nuova pseudo-riforma della giustizia civile, p. 30.
} 
desautorizar o mesmo procedimento com o uso de gravações audiovisuais. ${ }^{277}$ Não obstante, seria salutar que esta possibilidade ficasse expressa em lei, não apenas para afastar eventuais entendimentos em sentido contrário lastreados em formalismos exacerbados, mas também para difundir uma prática mais condizente com os tempos modernos, e que, demais disso, preserva a espontaneidade da palavra oral.

Em matéria de novas tecnologias de comunicação e produção de prova testemunhal, vale mencionar as disposições sobre a cooperação entre tribunais estabelecida pelo Regulamento (CE) n. 1206/2001 de 28 de maio de 2001, aplicável desde

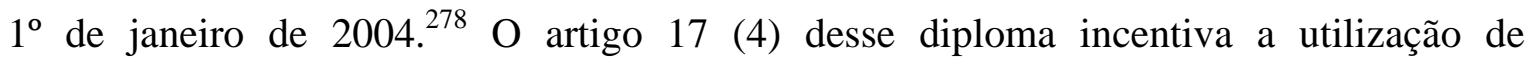
videoconferência e teleconferência para a produção de prova por um órgão jurisdicional fora dos limites territoriais de um país, evitando-se assim a necessidade de auxílio de um órgão jurisdicional estrangeiro na colheita da prova. Assim, por exemplo, se um tribunal alemão quiser ouvir uma testemunha residente na França, em vez de encaminhar um pedido para que um juiz francês realize uma audiência com tal finalidade, aconselha-se que o próprio juiz alemão realize a colheita do depoimento por via de videoconferência ou teleconferência. Para tanto, este procedimento precisa ser regulamentado por ambos os países.

Ora, tal modelo também poderia ser aplicado dentro dos limites territoriais de um mesmo país. Isso evitaria a necessidade de delegação de atos de instrução para a produção de prova testemunhal por meio de carta precatória e sequer haveria a necessidade de adquirir equipamentos caros; bastaria que a pessoa a ser ouvida estivesse diante de um computador com acesso à internet e uma webcam. Não há razão para transpor os rigores técnicos do processo penal para a oitiva de pessoas à distância para o âmbito do processo civil.

Equipamentos próprios para videoconferência ainda são custosos e poderiam ser substituídos sem perda significativa de qualidade pela transmissão via streaming por meio da internet.

277 BALENA, Giampiero. La nuova pseudo-riforma della giustizia civile, p. 30.

${ }^{278}$ Disponível em: <ec.europa.eu/civiljustice/evidence/evidence_net_en.htm>. Acesso em: 31 jul. 2009. 


\subsubsection{INAPLICABILIDADE DO RIGHT TO CONFRONTATION NO ÂMBITO DO PROCESSO CIVIL}

É importante frisar que a discussão acerca do uso de depoimentos escritos (affidavits) ou de videoconferências no processo civil não pode ser colocada no mesmo patamar da discussão correlata no âmbito do processo penal. Na seara do processo civil não se aplica a chamada garantia do confronto (right to confrontation ou confrontation clause).

O right to confrontation é uma garantia fundamental do réu no processo penal, pelo qual este tem o direito de estar presente na colheita da prova testemunhal. A ideia central da confrontation clause reside na suposição de que sempre será mais difícil para uma testemunha mentir em seu depoimento estando face a face com o acusado. ${ }^{279}$ Historicamente este direito surgiu com a Sexta Emenda à Constituição Americana, ${ }^{280}$ mas foi apenas em 1965 que a Suprema Corte Americana delineou seus contornos e nuances numa série de julgados sobre o tema, estabelecendo hipóteses em que essa regra poderia ceder em razão de outros valores.

No âmbito do processo civil, a admissão de declarações escritas como prova, em substituição à prova testemunhal, assim como o uso de videoconferência na inquirição de testemunhas, não envolve garantia processuais fundamentais das partes trata-se apenas de equação entre custo e qualidade da prova.

\subsection{AS NOVAS TECNOLOGIAS DA INFORMAÇÃO E AS FORMAS NO PROCESSO CIVIL}

O tema das novas tecnologias e as perspectivas de mudança no processo civil é um dos assuntos que mais têm despertado a atenção do processualista. Nos últimos dez anos, o tema mereceu um painel próprio em dois congressos mundiais da

\footnotetext{
279 SIEGEL, Larry J. Introduction to Criminal Justice. 12. ed. Wodsworth: Belmont, 2009. p. 454.

${ }^{280}$ In all criminal prosecutions, the accused shall enjoy the right to a speedy and public trial, by an impartial jury of the state and district wherein the crime shall have been committed, which district shall have been previously ascertained by law, and to be informed of the nature and cause of the accusation; to be confronted with the witnesses against him; to have compulsory process for obtaining witnesses in his favor, and to have the assistance of counsel for his defense. Destaque ausente no original.
} 
Associação Internacional de Direito Processual ( Procedural Law on the Threshold of a New Millennium, Viena, 1999; e Information Technology on Liigation, Salvador, 2007).

Não obstante, a percepção das mudanças promovidas pelo avanço tecnológico não são uniformes. AMRANI-MEKKI chega a afirmar que as novas tecnologias estão promovendo uma alteração tão significativa no processo civil, que a tradicional distinção entre forma escrita e forma oral do procedimento estaria em vias de demolição. $^{281}$

De outro lado, JANET WALKER e GARRY WATSON afirmam que a previsão de LORD WOOLF no sentido de que as tecnologias da informação seriam as novas bases dos sistemas judiciais (IT will be the foundation of the court system in the near future and now is the time that it should be receiving attention at the highest levels) até hoje não se concretizou. Deveras, segundo os autores, a revolução da tecnologia da informação foi muito menos sentida na administração da justiça do que em outras áreas públicas e no setor privado. $^{282}$

No âmbito dos países de Civil Law, JEULAND, em seu relatório geral para o Congresso de 2007 em Salvador, afirma que na grande maioria dos sistemas, as leis que permitiram a utilização de novas tecnologias no processo civil são extremamente recentes, e as experiências práticas ainda estão em fase de implementação e testes, o que impede que se faça uma avaliação dos seus impactos. ${ }^{283}$

A mesma percepção é verdadeira em relação aos países de Common Law. WALKER e WATSON afirmam que o progresso tecnológico nos tribunais tem sido recepcionado de forma muito lenta, possivelmente pela falta de independência financeira efetiva do Poder Judiciário em relação ao Executivo. The courts in common law jurisdictions with their very strong tradition of judicial independence are, nevertheless, ultimately dependant on the executive for funding and this puts them in a particular position of not being "masters of their own house" and readily able to martial the resources necessary to implement important reforms. ${ }^{284}$

281 SORAYA AMRANI-MEKKI. El impacto de las nuevas tecnologías sobre la forma del proceso civil. In: CARPI, Federico; ORTELLS, Manuel (Org.). Oralidad y Escritura en un Proceso Civil Eficiente, v. I, p. 93. ${ }^{282}$ WALKER, Janet; WATSON, Garry. New Technologies and the civil litigation process: Common Law General Report. In: GRINOVER, Ada Pellegrini; CALMON, Petrônio (Org.). Direito Processual Comparado. XIII World Congress of Procedural Law. Rio de Janeiro: Forense, 2007. p. 122.

283 JEUDLAND. Nouvelles Technologies et procès civil: Rapport Général pour les pays de Droit Civil. In: GRINOVER, Ada Pellegrini; CALMON, Petrônio (Org.). Direito Processual Comparado. XIII World Congress of Procedural Law. Rio de Janeiro: Forense, 2007. p. 153.

${ }^{284}$ WALKER, Janet; WATSON, Garry. New Technologies and the civil litigation process, p. 122. 
Os pontos mais importantes e sensíveis envolvem o peticionamento eletrônico, a entrega de documentos em formato eletrônico, a realização de audiências via videoconferência, e o registro e a documentação dos atos em formato eletrônico, que acabam por tangenciar o princípio da igualdade entre as partes, da publicidade dos atos e da oralidade, trazendo novos problemas ainda pouco discutidos.

Neste tópico, procurar-se-á discutir como a gravação das audiências e a videoconferência afetam a tradicional definição dos valores do princípio da oralidade, e quais são os problemas que já têm sido levantados acerca dessa prática na seara do processo civil.

\subsection{A GRAVAÇÃO DAS AUDIÊNCIAS, A VIDEOCONFERÊNCIA E A IMEDIAÇÃO}

A videoconferência, segundo afirma JEULAND, poderia dar um novo sentido para a audiência oral, cuja tendência atual é a sua substituição por um procedimento eminentemente escrito. ${ }^{285}$

Ao menos na Espanha, a videoconferência no processo civil é algo que já abandonou o estágio de mera previsão legal para se tornar uma realidade em muitos juízos, ainda que não possa ser considerada uma prática generalizada. ${ }^{286}$ Demais disso, outra prática razoavelmente difundida no país é a substituição das atas escritas da audiência pelo registro audiovisual do ato.

Neste país, a jurisprudência do Tribunal Constitucional sedimentou entendimento, na seara do processo penal, no sentido de reconhecer las insuficiencias del acta audiovisual del juicio para revisar en su totalidad El juicio del hecho efectuado en primera instancia, pues ni siquiera la filmácion es capaz de poner al órgano judicial de apelación en condiciones tales que le permitan emitir un juicio pleno sobre los hechos objeto de prueba y sobre las pruebas mismas. ${ }^{287}$

\footnotetext{
285 JEUDLAND. Nouvelles Technologies et procès civil, p. 177.

${ }^{286}$ GONZÁLES GARCIA. Oralidad y medios técnicos de grabación y reproducción de la imagen y del sonido en el proceso civil: haciendo de la necesidad virtud. In: CARPI, Federico; ORTELLS, Manuel (Org.). Oralidad y Escritura en un Proceso Civil Eficiente (Oral and Written Proceedings: Efficiency in Civil Procedure). v. II - Comunicaciones (Presentations). València: International Association of Procedural Law (IAPL), Universitat de València, 2008. p. 88.

${ }^{287}$ GONZÁLES GARCIA. Oralidad y medios técnicos de grabación y reproducción de la imagen y del sonido en el proceso civil, p. 91.
} 
Parte-se do pressuposto de que, para a reversão do julgamento em segundo grau com base exclusivamente na revisão da prova oral, esta deve necessariamente ser reproduzida no tribunal, sob pena de se violar a imediação na valoração da prova, sendo que a gravação da colheita da prova oral não serviria para evitar a necessidade de reprodução da prova. A ideia que subjaz toda essa construção é a crença de que por meio do contato direto com as testemunhas e as partes, o juiz poderia realizar um juízo de fidedignidade dos depoimentos.

Ocorre que há quem entenda que este entendimento deveria ser transposto para o processo civil, porquanto a Constituição Espanhola não teria feito a distinção entre o controle do juízo fático em matéria civil e em matéria penal. ${ }^{288}$ Segundo afirma MARTín, a apelação civil deveria retomar o rumo tradicional do processo oral, com a restauração da oralidade em segundo grau, reprodução das alegações das partes, e nova colheita da prova oral. ${ }^{289}$

Ora, levando-se esta concepção acerca do valor da imediação às últimas consequências, tal como o faz parte da doutrina espanhola, até mesmo o depoimento da testemunha por videoconferência não poderia ser admitido, pois, tal como na reprodução da audiência gravada, o contato direto entre o julgador e o depoente é em certa medida sacrificado em prol da celeridade. Tal resistência de parte da doutrina espanhola é injustificada, porquanto não há base científica para sustentar o suposto juízo de fidedignidade dos depoimentos com base no mero contato direito do juiz com as partes e testemunhas.

\footnotetext{
${ }^{288}$ GONZÁLES GARCIA. Oralidad y medios técnicos de grabación y reproducción de la imagen y del sonido en el proceso civil, p. 92.

${ }^{289}$ MARTíN. Oralidad y eficiencia del proceso civil: Ayer, hoy, y mañana. In: CARPI, Federico; ORTELLS, Manuel (Org.). Oralidad y Escritura en un Proceso Civil Eficiente, v. II, p. 34.
} 


\section{O MITO DO JUIZ POLÍGRAFO}

Ouvir de viva voz a narrativa de um fato não é o mesmo que ler a transcrição deste relato: eis uma ideia tão antiga que se perde no tempo e tão generalizada que transborda os limites das discussões jurídicas, constituindo quase que um senso comum. $^{290}$

O que não constitui um consenso é a razão pela qual a comunicação direta de viva voz entre os interlocutores deve ser valorizada. Sobre esta questão é possível categorizar duas ordens de explicações. A primeira refere-se ao maior grau de dialeticidade da comunicação oral. A comunicação escrita perde muito no que se refere à espontaneidade das respostas e interação entre os interlocutores, de modo que a comunicação oral seria mais eficiente segundo este aspecto.

A segunda ordem de explicações está atrelada à observação da linguagem corporal dos interlocutores e funda-se na crença de que os rubores, hesitações, gestos e olhares do depoente serviriam de base para uma espécie de juízo de fidedignidade do conteúdo do depoimento.

Neste sentido, MOACYR AMARAL SANTOS afirma que o depoimento escrito desnatura o caráter da prova testemunhal, que tem na originalidade das declarações a sua maior eficácia. ${ }^{291}$ Mais adiante, o autor explicita a importância da imediação pela possibilidade de o juiz valorar o depoimento pelo modo de falar da testemunha: O depoimento vale principalmente pela influência que exerce na formação da

\footnotetext{
${ }^{290}$ A suposta superioridade de significado da palavra falada em relação à palavra escrita é uma ideia tão trivial que há quem sustente que Platão assim já pensava. Cf. RICHARD, Marie-Dominique, L'enseignement oral de Platon. Paris : Cerf, 2005. Especificamente sobre o tema da prova testemunhal, o imperador romano Adriano já teria afirmado que o valor do testemunho presente não é o mesmo daquele prestado de forma indireta. (D. 22.5.3.4 Alia est auctoritas praesentium testium, alia testimoniorum quae recitari solent: tecum ergo delibera, ut, si retinere eos velis, des eis impendia). Entre os pós-glosadores, PIERRE AYRAULT, discípulo de Jacques Cujacius, já no século XVI, ao tratar da prova testemunhal, após fartas citações de Cícero, afirma que a boca mente com frequência, mas os gestos são mais sinceros, aduzindo com isso que o julgador deveria atentar para tal circunstância. AYRAULT, Pierre. L'Ordre, Formalité, et Instruction Judiciaire. Paris : J. Caffin e F. Plaignard, 1642. p. 374, parágrafo 69. Não se pretende aqui traçar qualquer linha de continuidade entre aqueles que expressaram tais ideias, mas apenas ilustrar como que tal assertiva não é produto de uma época específica. Trata-se de uma constatação tão comum que poderia se afirmar que deflui da própria experiência cotidiana, passível de ser formulada em qualquer sociedade onde a escrita seja difundida.

${ }^{291}$ SANTOS, Moacyr Amaral. Prova Judiciária no Cível e Comercial. v. II. 4. ed. São Paulo: Max Limonad, 1971. p. 533.
} 
convicção do juiz. No modo de responder, ao afirmar, negar ou narrar os fatos, tem o juiz prudente e avisado, observador e psicólogo, manancial precioso para apreciar devidamente o valor do depoimento. ${ }^{292}$ Demais disso, afirma-se ainda que a solenidade da audiência e o fato de a testemunha estar frente a frente ao juiz induziriam-na a dizer a verdade. ${ }^{293}$

Se prevalecer a tese segundo a qual o juiz tem esta capacidade de determinar a fidedignidade do depoimento pela observação da linguagem corporal e do modo de falar do depoente, o julgador que colhesse a prova oral deveria fazer tais peculiaridades constarem dos autos, tal como ocorria nas Ordenações Filipinas:

E attentem bem com que aspecto e constancia fallam, e se variam, ou vacillam, ou mudam a cor, ou se torvam na falla, em maneira, que lhes pareça, que são falsas, ou suspeitas. E quando assi o virem, ou sentirem, devem-no notificar ao Julgador do Feito, se for no lugar onde se tiram a inquirição: e se for absente,mandarão aos Scrivães, ou Tabelliães que screvam as ditas torvações e desvarios das testemunhas, a que acontecer, para o Juiz, que houver de julgar o feito, prover nisso, como lhe parecer justiça. (Ord. Fil. 1.86.1).

Na Argentina, CARLOS ALBERTO CARBOnE afirma que o juiz pode fazer constar da ata de audiência a descrição do comportamento corporal da testemunha, suas hesitações e entonações de voz, pois tais dados seriam relevantes para a correta avaliação da prova testemunhal. ${ }^{294}$

\footnotetext{
${ }^{292}$ SANTOS, Moacyr Amaral. Prova Judiciária no Cível e Comercial, p. 221. Trata-se de afirmação amplamente generalizada. Na Argentina, JORGE PEYRANO afirma que la referida percepción directa judicial que permite la inmediación procesal mediante la actuación de la prueba frente a los ojos y oídos judiciales, possibilita que el magistrado presente perciba también, por ejemplo, el llamado lenguaje corporal o no verbal que integra la comunicación junto con el verbal. Es que toda comunicación personal utiliza dos medios, uno vernal y el otro gestual. Por eso se ha dicho es casi tan necesario ver el interrogatorio como oírlo. PEYRANO, Jorge W. La Prueba entre la Oralidad y la Escritura. In: CARPI, Federico; ORTELLS, Manuel (Org.). Oralidad y Escritura en un Proceso Civil Eficiente (Oral and Written Proceedings: Efficiency in Civil Procedure). v. I - Ponencias generales e informes nacionales (General reports and national reports). València: International Association of Procedural Law (IAPL), Universitat de València, 2008. p. 161.

${ }^{293}$ PEYRANO, Jorge W. La Prueba entre la Oralidad y la Escritura, p. 156.

${ }^{294}$ Nosostros nos enrolamos en la corriente de opinión que expresa que, salvo expresa prohibición legal, el juez puede hacer constar a través del actuario los gestos antes ejemplificados: pensamos que no se trata de tener especiales percepciones psicológicas o dotes extraordinarios para hacer constar un quiebre de voz, una desviación aislada o permanente de la mirada hacia el careado o hacia el juez, un llanto, un rubor o sobresalto ante una pregunta, o lágrimas, sonrisas, silencios prologados, ante determinadas preguntas o confrontaciones con objetos o personas realizadas en las audiencias, etcétera, por cuanto tales constancias constituyen datos objetivos no sustentados en subjetividades arbitrarias o descabelladas del tribunal. CARBONE, Carlos Alberto. Interés de documentar el comportamiento procesal relevante de las partes en el proceso escrito. In: ACOSTA, Daniel; PEYRANO, Jorge (Org.). Valoración Judicial de la Conducta Procesal. Santa Fe: Rústica, 2005. p. 286 apud PEYRANO, Jorge W. La Prueba entre la Oralidad y la Escritura, p. 161-162, nota 77.
} 
De outro lado, JORGE PEYRANO repudia tal entendimento, sob o argumento de que a dificuldade prática em se redigir a ata de audiência com tais observações e os questionamentos das partes em relação ao conteúdo da ata desaconselhariam tal procedimento. ${ }^{295}$ Deveras, se juiz tivesse o dever de fazer constar de ata de audiência toda sorte de detalhamento sobre o comportamento de partes e testemunhas, as pautas de audiência iriam se alongar de tal forma que inviabilizariam tal prática.

Há de se notar que ambos os autores partem da premissa equivocada - segundo a qual o juiz tem o dom de perceber a falsidade de um depoimento pela linguagem corporal do depoente, e que tal percepção subjetiva é um elemento legítimo na formação da conviç̧ão do juiz. Ao contrário disso, acredita-se que o juiz deve, ao máximo, desconsiderar tais idiossincrasias, de modo que somente poderia julgar com base em dados objetivos).

O raciocínio de CARBONE é coerente, mas por partir de uma premissa equivocada chega a uma conclusão igualmente equivocada. Já o pensamento de PEYRANO não é coerente, pois se a leitura da linguagem corporal do depoente fosse realmente um método válido para a aferição da veracidade de um depoimento, para fins de prova judicial, as impressões do julgador deveriam constar dos autos, tal como dispunham as Ordenações Filipinas.

TARUFFO afirma que é preciso questionar até que ponto a tradicional assertiva segundo a qual a imediação na colheita da prova oral permitiria ao juiz realizar um juízo acurado de fidedignidade do depoimento com base na linguagem corporal da testemunha, sua entonação de voz, seus rubores e reticências possui efetivamente algum respaldo científico. ${ }^{296}$

Deveras, deve-se reconhecer que a linguagem corporal e a capacidade da testemunha de responder prontamente sem reticências são critérios de duvidosa confiabilidade e cientificidade. Para o homem simples, estar numa sala de audiências diante de juiz e advogados é um fato que escapa completamente ao seu cotidiano, de modo que o nervosismo e a dificuldade em articular as respostas às perguntas que lhe foram formuladas é uma reação perfeitamente compreensível, ainda que seja totalmente genuíno seu depoimento. De outra banda, algumas pessoas possuem o controle

${ }^{295}$ PEYRANO, Jorge W. La Prueba entre la Oralidad y la Escritura, p. 164.

296 TARUFFO, Michele. Orality and writing as factors of efficiency in civil litigation, p. 197. 
emocional e a velocidade de raciocínio necessários para fornecer respostas falsas de forma rápida e calma. ${ }^{297}$

A rigor, tem se questionado até mesmo a confiabilidade da análise realizada por técnicos especializados com o auxílio de polígrafos - equipamentos desenvolvidos para monitorar respostas fisiológicas do corpo humano, tais como ritmo cardíaco, pressão sanguínea, ritmo respiratório, e temperatura corporal, e que serviriam, em tese, para atestar a validade de respostas. Segundo pesquisa realizada pelo Office of Technology Assessment do Congresso norte-americano, em determinadas circunstâncias extremas, o índice de acerto do polígrafo não supera 57,9\%, de modo que ainda que o instrumento possa ser útil na área militar e de segurança nacional, a sua utilidade como prova judicial pode ser questionada. ${ }^{298}$

Ora, se não pode afirmar que a análise da veracidade ou falsidade dos depoimentos, realizada por técnicos especializados, com equipamentos especificamente desenvolvidos para tanto, possui eficácia empiricamente comprovada, como maior razão não se poderá confiar na intuição de alguém que não recebeu qualquer treinamento para tal tarefa, e ainda sem o auxílio de qualquer equipamento.

Como afirma TARUFFO, a oralidade na colheita da prova e a observação do comportamento do depoente em audiência não podem servir de meio para a obtenção de informações acerca da credibilidade do depoimento. At any rate, it has to be excluded that the immediate contact of the trier of fact with the witness may lead to a sort of divination of the truth or a subjective intuition about whether the witness told or did not

\footnotetext{
${ }^{297}$ JORGE PEYRANO reconhece que esta suposta habilidade do juiz em perceber a mendacidade do depoimento é em grande parte prejudicada pelo grau de sensibilidade do depoente. Además, la conducta emotiva es equívoca, dependiendo del grado de sensibilidad del declarante (que experimenta, por ejemplo, temor reverencial ante la presencia del juez); requiriendo una inusual finura psicológica separar "la paja del trigo", es decir la conducta del mendaz del proceder del particularmente sensible a raíz de su comparecencia frente a los estrados judiciales. PEYRANO, Jorge W. La Prueba entre la Oralidad y la Escritura, p. 163.

${ }^{298}$ OFFICE OF TECHNOLOGY ASSESSMENT - US CONGRESS. Scientific Validity of Polygraph Testing: A Research Review and Evaluation.Technical Memorandum. Washington D.C., 1983. cap. 7. Em 1998, a Suprema Corte Norte-Americana, no caso Scheffer v. United States, considerou constitucional a Military Rule of Evidence 707, que veda o uso de teste de polígrafo como prova nas Cortes Marciais. O condenado Edward Scheffer alegava violação ao seu direito de defesa, pois o resultado de um teste de polígrafo que the havia sido favorável não havia sido admitido pela Corte Marcial como prova. A Suprema Corte afirmou ser constitucional o dispositivo questionado, pois não havendo consenso na comunidade científica acerca da validade do teste de polígrafo, a restrição ao seu uso como prova é legítima. Cumpre anotar, no entanto, que tal conclusão não significa absolutamente que a Suprema Corte tenha concluído pela inadmissibilidade do teste do polígrafo como prova judicial, o qual ainda é admitido em diversos estados norte-americanos.
} 
told the truth. ${ }^{299}$ Ou seja, a imediação e a oralidade na produção da prova testemunhal não possuem o valor de permitir ao julgador avaliar a veracidade ou falsidade dos depoimentos como base em dados como a entonação de voz, hesitações, rubores, nervosismo, etc., sob pena de o juiz sujeitar as partes a um verdadeiro jogo de adivinhação.

No mesmo sentido, FRANÇOIS GORPHE afirma que, por maior que seja a experiência profissional e a perspicácia do juiz, ele não é um adivinho, e portanto não é capaz de penetrar no coração e nos pensamentos dos depoentes. ${ }^{300} \mathrm{O}$ que ocorre com frequência é que, com o passar dos anos de exercício na judicatura, muitos juízes desenvolvem a convicção de que são capazes de desvelar a mendacidade de um depoimento com base em elementos de linguagem corporal, sendo que em verdade essa suposta técnica constitui mero exercício de adivinhação.

Vale notar que a linguagem corporal não se confunde com elementos objetivos perceptíveis a partir de um contato direto do juiz com as partes do processo. É o que ocorre, por exemplo, nas demandas previdenciárias na qual o autor pleiteia a aposentadoria por tempo de serviço rural. Nestes casos, o contato direto do juiz com aquele que alega, em audiência, ter sido trabalhador rural é capaz de oferecer ao julgador elementos objetivos na formação de seu convencimento: as mãos calejadas, a pele fustigada pelo sol, as roupas trajadas, e o linguajar utilizado.

Aliás, nesses casos, o melhor método de se distinguir o empreendedor rural - que nunca exerceu diretamente o trabalho no campo e que não faz jus à aposentadoria por tempo de serviço rural - do trabalhador rurícola braçal é o próprio contato direto em audiência. Todavia, nesta situação, deve o julgador expor suas percepções objetivas na fundamentação da sentença.

\footnotetext{
299 TARUFFO, Michele. Orality and writing as factors of efficiency in civil litigation, p. 197.

300 GORPHE, François. La critica del testimonio. 5. ed. Tradução de Mariano Ruiz Funes. Madrid: Reus, 1971. p. 62.
} 


\section{O VERDADEIRO VALOR DA IMEDIAÇÃO E A FALSIDADE DO PARADOXO “ORALIDADE E DUPLO GRAU DE JURISDIÇÃO”}

O legítimo valor da imediação no contato entre juiz, partes e testemunhas está na possibilidade de interação imediata do juiz com os depoentes, e a imprevisibilidade das perguntas que poderão ser formuladas. Isso porque, a imediação dificulta a construção de relatos falsos, mas coerentes, pois tolhe a possibilidade de o depoente refletir sobre todas as imbricações da falsa assertiva. O poeta Alexander Pope transmitiu tal noção numa síntese tão clara que merece ser reproduzida: He who tells a lie, is not sensible how great a task he undertakes; for he must be forced to invent twenty more to maintain that one.

Isso significa que a arte do juiz está em manejar as perguntas de maneira a desvelar o falso relato preparado de antemão, ${ }^{301}$ não lhe sendo lícito realizar um exercício de adivinhação com base na linguagem corporal do depoente.

Nestes termos, o depoimento da testemunha que comparece fisicamente perante o juiz e daquela que se apresenta mediante videoconferência é exatamente o mesmo, desde que a comunicação seja em tempo real.

Do mesmo modo, a legitimidade da valoração que o julgador de segundo grau faz da prova oral gravada em meio audiovisual é a mesma daquela feita pelo juízo de primeiro grau. $O$ único aspecto que se perde em segundo grau é a possibilidade de o julgador realizar novas perguntas de forma imediata, mas tal aspecto é remediado na generalidade dos ordenamentos com a previsão de baixa dos autos para novas diligências, ou até mesmo de realização da prova diretamente em segundo grau.

Assiste razão, portanto, a PICÒ Y JUNOY e CERRATO GURI, ao afirmarem que a configuração da segunda instância como revisio prioris intantiae é plenamente compatível com a possibilidade de se controlar a valoração judicial da prova oral gravada em meio audiovisual em segundo grau, não havendo que se falar em nenhuma vulneração à imediação. ${ }^{302}$

${ }^{301}$ GORPHE, François. La critica del testimonio, p. 63-64.

${ }^{302}$ PICÓ I JUNOY, Juan; CERRATO GURI, Elisabet. El control de la valoración judicial de las pruebas personales en la segunda instancia civil. In: CARPI, Federico; ORTELLS, Manuel (Org.). Oralidad y Escritura en un Proceso Civil Eficiente, v. II, p. 233. 
Caso não se concordasse com a tese ora exposta, ou seja, caso se atribuísse legitimidade ao juízo de fidedignidade do depoimento fundado na linguagem corporal da testemunha, seria preciso reconhecer que o juiz teria o dever de deixar registrado nos autos suas impressões subjetivas acerca do comportamento da testemunha em audiência.

TARUFFO afirma que o juiz deve explicitar as razões pelas quais ele considera uma testemunha digna de fé ou não, sendo que tal dever seria um desdobramento daquilo que ele denomina de principio della completezza della motivazione. ${ }^{303}$ Nestes termos, se o juízo de fidedignidade do depoimento lastreado em impressões subjetivas acerca do comportamento do depoente for tido como legítimo - o que não é, diga-se de passagem, o entendimento aqui defendido -, seria preciso que o juiz fizesse constar dos autos tais impressões.

Ora, se fosse admitida tal capacidade praticamente sobre-humana do juiz de interpretar a linguagem corporal da testemunha com níveis de segurança suficientes para legitimá-lo a desqualificar um depoimento, seria preciso que ele fizesse constar da ata da audiência e da motivação da sentença quais seriam estes elementos por ele observados, de modo que em segundo grau o tribunal tivesse dados suficientes para revalorar a prova. Apenas deste modo seria possível desfazer o paradoxo entre oralidade e duplo grau de jurisdição existente no pensamento daqueles que atribuem ao juiz tal capacidade.

${ }^{303}$ TARUFFO, Michele. Considerazioni su prova e motivazione. In: MEDINA, José Miguel Garcia; CRUZ, Luana Pedrosa de Figueiredo; CERQUEIRA, Luis Otávio Sequeira de; GOMES JÚNIOR, Luiz Manoel (Coord.). Os Poderes do Juiz e o Controle das Decisões Judiciais - Estudos em Homenagem à Professora Teresa Arruda Alvim Wambier. São Paulo, Revista dos Tribunais, 2008. p. 171. 


\section{ORALIDADE NAS DEMANDAS ENVOLVENDO DIREITO DE FAMÍLIA}

JACQUES VELU afirma que o comparecimento em audiência não é uma garantia fundamental das partes no processo civil na generalidade dos casos. Todavia, o autor sustenta que dependendo do direito material discutido, esta apresentação pessoal poderia sim ser considerada um pressuposto para um processo justo, desde que se tratasse de um caso em que o contato direto do juiz com as partes fosse determinante para a formação da convicção do julgador. ${ }^{304}$

Deveras, em relação aos litígios envolvendo relações familiares, o contato direto entre juiz e partes revela uma importância especial. Em algumas situações, este contato possui um efeito pedagógico em relação aos litigantes. Em outras situações, como por exemplo nos casos envolvendo violência doméstica, destituição do poder familiar ou alteração de guarda, a própria solenidade da audiência e a advertência do magistrado em relação à conduta inapropriada de algum dos litigantes é capaz de provocar alterações na relações familiares.

É claro que não deve o juiz assumir uma postura paternal para aconselhar os jurisdicionados acerca da condução de sua vida privada. Todavia, a mera advertência do juiz no sentido de que a manutenção de uma postura displicente em relação aos filhos poderá acarretar suspensão ou perda do poder familiar, sem prejuízo das sanções penais cabíveis, por vezes pode ser suficiente para gerar uma mudança de comportamento.

\footnotetext{
${ }^{304}$ A afirmação do autor é escorada numa decisão da antiga Comissão Europeia de Direitos Humanos, nos seguintes termos: Qu'il est clair que le droit de comparaître en personne dans une action civile n'est pas en tant que tel garanti par cette disposition de l'article 6, par. 1, ni par aucune autre disposition de la Convention; que, toutefois, la question se pose de savoir si, dans certaines catégories d'affaires ou dans certaines circonstances, le droit à un procés equitable garanti par l'article 6, par. 1, n'implique pas le droit de comparaître en personne et que cette catégorie d'affaires où le caractère et le comportement personnels de l'une des parties contribuent directement à former l'opinion du tribunal sur le point qu'il est appelé à trancher paraît bien être l'une de celles où la question se pose avec une particulière importance; qu'au surplus, une affaire dans laquelle l'un des parents, à la suite d'un divorce, demande au tribunal le droit de visiter l'enfant né du mariage rentre indubitablement dans cette catégorie. VELU, Jacques. La Convention Européenne des Droits de L’Homme et les garanties fondamentales des parties dans le procès civil. In: CAPPELLETTI, Mauro ; TALLON, Denis (Ed.). Fundamental Guarantees of the Parties in Civil Litigation. Milano; New York: Giuffrè; Oceana, 1971. p. 309.
} 
Contudo, não é adequado elevar o contato direto do juiz com as partes à categoria de pressuposto para um processo justo em todas as demandas envolvendo direito de família. Em muitas situações, como por exemplo nas demandas envolvendo alimentos, a tentativa de conciliação pode ser conduzida por um conciliador especialmente qualificado para este fim.

É o que ocorre em diversas comarcas paulistas, com esteio no Provimento n. 893/2004-CSM- TJSP, parcialmente modificado pelo Provimento n. 953/2005-CSM. Nesta situação, não há que se falar em violação ao devido processo legal, haja vista que mesmo sem um contato direto do juiz com as partes, havendo acordo, há de se admitir que a demanda recebeu um tratamento adequado. 


\section{CONCLUSÃO}

A racionalização das atividades do juiz e das partes na fase preliminar como medida tendente a reduzir custos é uma preocupação presente em todos os sistemas processuais modernos. As restrições orçamentárias quanto aos gastos do Poder Judiciário não são exclusividade de países em desenvolvimento, sendo certo que esta é também a dura realidade de países como Japão, Alemanha e Inglaterra.

O dilema que se enfrenta é saber até que ponto se está disposto a sacrificar a qualidade da justiça oferecida em prol da redução de custos. Trata-se, em outras palavras, do eterno conflito do processualista: equacionar segurança e celeridade.

Nesta perspectiva, é preciso repensar alguns princípios do direito processual civil. A sobrevalorização da oralidade tem se demonstrado contraproducente, sendo que por vezes a vantagem obtida com essa técnica não justifica o seu maior custo. É o caso do regime obrigatório da audiência preliminar, que mesmo a Áustria - onde o princípio da oralidade goza de status constitucional - já abandonou há tempos.

Por outro lado, a tentativa obrigatória de conciliação, como forma de aumentar os níveis de acordo, aliviando os tribunais, precisa ser vista com grande cautela. O risco é que, tal como ocorreu com o Japão, a conciliação sirva para mascarar sérios obstáculos ao acesso à justiça. Demais disso, as experiências canadense e alemã demonstraram que a tentativa de conciliação obrigatória tem se revelado pouco eficiente, por tolher a voluntariedade que lhe é ínsita.

A produção da prova testemunhal é outro ponto de estrangulamento quando se discute a racionalização do tempo do juiz em primeira instância. Não se questiona que a presença da testemunha perante o juiz importe uma prova qualitativamente melhor. $O$ que se quer afirmar é que, dependendo das circunstâncias do caso concreto, seria salutar admitir os depoimentos escritos ou gravados, que, ademais, buscam também destacar o papel do advogado na produção das provas.

Uma hipótese exemplar é a oitiva de testemunha por carta precatória. Neste caso, a imediação já foi sacrificada, não havendo sentido algum desperdiçar o tempo do juiz deprecado numa atividade meramente notarial. Seria muito 
mais econômico permitir a entrega de depoimentos escritos, tal como permite a recente legislação italiana. Outra solução possível - e que preservaria a imediação - seria fazer uso da videoconferência como forma de substituição da delegação da colheita da prova, tal como sugere a European Small Claims Procedure.

Estas considerações levam à valorização da flexibilidade no procedimento, que permite ao juiz evitar a realização de atos desnecessários e infrutíferos, respondendo ao anseio de racionalização dos gastos do Poder Judiciário e ao dever de colaboração entre as partes, advogados e juiz no processo, que não apenas serve como fator de maior qualidade na prestação jurisdicional, mas também funciona como contrapeso ao aumento dos poderes do juiz na customização do procedimento. 


\section{BIBLIOGRAFIA}

ALMEIDA, Cândido Mendes de. Código Philippino ou Ordenações e Leis do Reino de Portugal recopiladas por mandado D'el-Rey D. Phillippe I. 14. ed. Rio de Janeiro: Typographia do Instituto Philomáthico, 1870.

AMRANI-MEKKI, Soraya. El impacto de las nuevas tecnologías sobre la forma del proceso civil. In: CARPI, Federico; ORTELLS, Manuel (Org.). Oralidad y Escritura en un Proceso Civil Eficiente (Oral and Written Proceedings: Efficiency in Civil Procedure). v. I - Ponencias generales e informes nacionales (General reports and national reports). València: International Association of Procedural Law (IAPL), Universitat de València, 2008.

ANDREWS, Neil. The pre-action-phase - General Report - Common Law. In: GRINOVER, Ada Pellegrini; CALMON, Petrônio (Org.). Direito Processual Comparado. XIII World Congress of Procedural Law. Rio de Janeiro: Forense, 2007.

ATTILIO, Nicora. Il principio di oralità nel diritto processuale civile italiano e nel diritto processuale civile canonico. Series Facultatis Iuris Canonici. Roma: Università Gregoriana, 1977.

AYRAULT, Pierre. L'Ordre, Formalité, et Instruction Judiciaire. Paris : J. Caffin e F. Plaignard, 1642.

AZEVEDO, Luiz Carlos; CRUZ E TUCCI, José Rogério. Lições de História do Processo Civil Romano. São Paulo, Revista dos Tribunais, 2001.

BALENA, Giampiero. La nuova pseudo-riforma della giustizia civile. 29 jul. 2009. Disponível em: <www.judicium.it>. Acesso em: 30 jul. 2009.

BAPTISTA, Francisco de Paula. Compendio de Theoria e Pratica do Processo Civil comparado com o Commercial e de hermenêutica jurídica. 8. ed. São Paulo: Saraiva, 1909.

BARBOSA MOREIRA, José Carlos. Saneamento do Processo e Audiência Preliminar. Temas de Direito Processual (Quarta Série). São Paulo: Saraiva, 1989.

. Vicissitudes da audiência preliminar. Temas de Direito Processual (Nona Série). São Paulo: Saraiva, 2007.

BAUR, Fritz. Les Garanties Fondamentales des Parties dans le Procés Civil em République Fédérale d’Allemagne. In: CAPPELLETTI, Mauro ; TALLON, Denis (Ed.). Fundamental Guarantees of the Parties in Civil Litigation. Milano; New York: Giuffrè; Oceana, 1971. 
BEDAQUE, José Roberto dos Santos. Novas Tendências em matéria de fase preliminar Relatório de Síntese. In: GRINOVER, Ada Pellegrini; CALMON, Petrônio (Org.). Direito Processual Comparado. XIII World Congress of Procedural Law. Rio de Janeiro: Forense, 2007.

BENDER, Rolf. The Stuttgart Model. In: CAPPELLETTI, Mauro; WEISNER John (Ed.). Access to Justice. v. II. Book II. Milano: Giuffrè, 1979.

BENTHAM, Jeremy. Traité des Preuves Judiciaires. Tradução e compilação dos manuscritos por Étienne Dummont. Paris: Bossange Frères, 1823.

BIONDI, Biondo. Il diritto romano cristiano. v. 3. Milano: Giuffrè, 1954. . Summatim Cognoscere. Bullettino dell’ Istituto di Diritto Romano, ano 30, 1921.

BOTELHO DE MESQUITA, José Ignácio. As novas tendências do direito processual: uma contribuição para o seu reexame. In: Teses, Estudos e Pareceres de Processo Civil. v. 1. São Paulo: Revista dos Tribunais, 2005.

BREYER. Relatório alemão apresentado ao painel Novas Tendências nos Procedimentos Preliminares, do XIII Congresso Mundial de Direito Processual (Brasil-2007) apud ANDREWS, Neil. The pre-action-phase - General Report - Common Law. In: GRINOVER, Ada Pellegrini; CALMON, Petrônio (Org.). Direito Processual Comparado. XIII World Congress of Procedural Law. Rio de Janeiro: Forense, 2007.

BRIGUGLIO, Antonio. Le novità sul processo ordinario di cognizione nell'ultima, ennesima riforma in materia di giustizia civile. Disponível em: <www.judicium.it>. Acesso em: 30 jul. 2009.

CAETANO, Marcello. História do Direito Português. 4. ed. Lisboa: Verbo, 2000.

CAMBI, Eduardo. A Prova Civil: admissibilidade e relevância. São Paulo: Revista dos Tribunais, 2006.

CAMPITELLI, Adriana. Processo Civile (dir. interm.). Enciclopedia del Diritto, XXXVI. Milano: Giuffrè, 1987.

CAMPOS, Francisco. Reforma do Processo Civil. In: Processo Oral. Rio de Janeiro: Forense, 1940.

CARNELUTTI, Francesco. Addio, Chiovenda. Rivista di Diritto Processuale, Padova, Cedam, v. 3, Parte I, 1948.

CAPPELLETTI, Mauro. La testimonianza della parte nel sistema dell'oralità Contributo alla teoria della utilizzazione probatoria nel sapere delle parti ne processo civile. Parte Prima. Milano: Giuffrè, 1974.

. Procédure Orale et Procédure Écrite - Oral and Written Procédure in Civil Litigation. Milano; New York: Giuffrè; Oceana, 1971. 
CARRELLI, Odorardo. La genesi del procedimento formulare. Milano: Giuffrè, 1946.

CERRATO GURI, Elisabet; PICÓ I JUNOY, Juan. El control de la valoración judicial de las pruebas personales en la segunda instancia civil. In: CARPI, Federico; ORTELLS, Manuel (Org.). Oralidad y Escritura en un Proceso Civil Eficiente (Oral and Written Proceedings: Efficiency in Civil Procedure). v. II - Comunicaciones (Presentations). València: International Association of Procedural Law (IAPL), Universitat de València, 2008.

CHIOVENDA, Giuseppe. Le forme nella difesa giudiziale del diritto. In: Saggi di Diritto Processuale. v. I. Milano: Giuffrè, 1993.

. Relazione su progetto di riforma del procedimento elaborato dalla Coomissione per il dopo guerra. In: Saggi di Diritto Processuale. v. II. Milano: Giuffrè, 1993.

Sul rapporto fra le forme del procedimento e la funzione della prova (l'oralità e la prova). In: Saggi di Diritto Processuale. v. II. Milano: Giuffrè, 1993.

. L’idea romana nel processo civile moderno. In: Saggi di Diritto Processuale, v. 3. Milano: Giuffrè, 1993.

Sulla influenza delle idee romane nella formazione dei processi civili moderni. In: Saggi di Diritto Processuale Civile. Milano: Giuffrè, 1993.

. Cosa giudicata e preclusione. In: Saggi di Diritto Processuale Civile. v. 3. Milano: Giuffrè, 1993.

La riforma del procedimento civile. In: Saggi di Diritto Processuale Civile. v. 3. Milano: Giuffrè, 1993.

Sulla riforma del Processo Civile. Intervista di Roberto Bisceglia. In: Saggi di Diritto Processuale Civile, v. 3. Milano: Giuffrè, 1993.

Instituições de Direito Processual Civil. v. I. 3. ed. Tradução de J. Guimarães Menegale. São Paulo: Saraiva, 1969. n.16-A. 309.

Instituições de Direito Processual Civil. v. 3. 2. ed. São Paulo: Saraiva, 1965. n.

CIPRIANI, Franco. Giuseppe Chiovenda, il Manifesto Croce e il Fascismo. Rivista di Diritto Civile, Padova, Cedam, ano XLI, n. 1, 1995.

Nel centenario del Regolamento di Klein (Il processo civile trà libertà e autorità). Rivista di Diritto Processuale, Padova, Cedam, n. 4, 1995.

COSTA, Moacyr Lobo da. Breve notícia histórica do Direito Processual Civil Brasileiro e de sua literatura. São Paulo: Revista dos Tribunais, 1970.

CRUZ E TUCCI, José Rogério; AZEVEDO, Luiz Carlos. Lições de História do Processo Civil Romano. São Paulo: Revista dos Tribunais, 2001. 
CRUZ E TUCCI, José Rogério; AZEVEDO, Luiz Carlos. Lições de Direito Processual Civil Canônico. São Paulo: Revista dos Tribunais, 2001. p. 36-37.

DAKOLIAS, Maria. The Judicial Sector in Latin America and the Caribbean. Washington: World Bank Publications, 1996.

DAMAŠKA, Mirjan. Evidence Law Adrift. New Haven-London, Yale University, 1997.

DINAMARCO, Cândido Rangel. A Reforma do Código de Processo Civil. 2. ed. São Paulo: Malheiros, 1995. Instituições de Direito Processual Civil. 3. ed. v. 1. São Paulo: Malheiros, 2003.

EICHMANN, Eduard. Manual de Derecho Eclesiástico a tenor del Codex Juris Canonici. Trad. da 3. ed. alemã de T. Gómez Piñan. t. II. Barcelona: Libreria Bosch, 1931.

ESPÍNOLA, Eduardo. Código do Estado da Bahia Annotado. Typ. Bahiana de Cincinnato Melchiades, 1918.

ESTELITA, Guilherme. O Processo Oral e sua Adoção no Brasil. Revista Forense. Rio de Janeiro, p. 115-117, maio 1938.

FIGUEIREDO, José Anastácio. Sobre a origem dos nossos Juízes de Fora. In: Memorias da Litteratura Portugueza. t. I. Lisboa: Academia Real das Sciencias de Lisboa, 1792.

FIORI, Roberto. Homo sacer: dinamica politico costituzionale di una sanzione giuridicoreligiosa. Napoli: Jovene, 1996.

FREIRE, Pascoal José de Mello. Instituições de Direito Civil Português. Tradução de Miguel Pinto Meneses. Boletim do Ministério da Justiça, Lisboa, n. 161-162, 1966.

GAJARDONI, Fernando da Fonseca. Técnicas de aceleração do processo. São Paulo: Lemos e Cruz, 2003.GERALDES, António Santos Abrantes. Temas da Reforma do Processo Civil. v. II. 4. ed. Coimbra: Almedina, 2004.

GONZÁLES GARCIA. Oralidad y medios técnicos de grabación y reproducción de la imagen y del sonido en el proceso civil: haciendo de la necesidad virtud. In: CARPI, Federico; ORTELLS, Manuel (Org.). Oralidad y Escritura en un Proceso Civil Eficiente (Oral and Written Proceedings: Efficiency in Civil Procedure). v. II Comunicaciones (Presentations). València: International Association of Procedural Law (IAPL), Universitat de València, 2008.

GORPHE, François. La critica del testimonio. 5. ed. Tradução de Mariano Ruiz Funes. Madrid: Reus, 1971.

GOTTWALD, Peter. Civil Procedure Reform in Germany. American Journal of Comparative Law, n. 45, 1997. 
GUIMARÃES, Luís Machado. O Processo Oral e o Processo Escrito. Revista Forense. Rio de Janeiro, p. 30-37, maio 1938.

HALEY, John Owen. The Myth of Reluctant Litigant. Journal of Japanese Studies, v. 4, n. 2, p. 359-371, verão de 1978.

HELMHOLZ, R. H. Undue delay in English Ecclesiastical Courts (circa 1350-1600). In: RHEE, C. H. van (Org.). The Law's Delay: Essays on Undue Delay in Civil Litigation. Intersentia, 2004.

HOMBURGUER, Adolf. Functions of Orality in Austrian and American Civil Procedure. Buffalo Law Review, n. 20, p. 9-39, 1970.

HONMA, Manabu. The Preliminary Phase and the Trial Agreement in Japan. In: CARPI, Federico; ORTELLS, Manuel (Org.). Oralidad y Escritura en un Proceso Civil Eficiente (Oral and Written Proceedings: Efficiency in Civil Procedure). v. I Ponencias generales e informes nacionales (General reports and national reports). València: International Association of Procedural Law (IAPL), Universitat de València, 2008.

JACOBS, Paul. A Recent Comparative History of Mandatory Mediation vs Voluntary Mediation in Ontario, Canada. International Bar Association Mediation Newsletter, abr. 2005.2 Disponível em: <www.msmlaw.net/Resources/Mandatory.vs.Voluntary.Media.pdf>. Acesso em: 22 jul. 2009.

JEUDLAND. Nouvelles Technologies et procès civil: Rapport Général pour les pays de Droit Civil. In: GRINOVER, Ada Pellegrini; CALMON, Petrônio (Org.). Direito Processual Comparado. XIII World Congress of Procedural Law. Rio de Janeiro: Forense, 2007.

JOLOWICZ, Herbert Felix. Historical Introduction to the Study Roman Law. Cambridge: Cambridge University, 1952.

JOLOWICZ, John Antony. On Civil Procedure. Cambridge: Cambridge University, 2000.

KASER, Max. Das Altrömische ius: Studien zur Rechtsvorstellung und Rechtsgeschichte der Römer. Göttingen: Vandenhoeck \&Ruprecht, 1949.

Direito Privado Romano. Tradução de Samuel Rodrigues e Ferdinand Hämmerle e revisão de Maria Armanda de Saint Maurice. Lisboa: Fundação Calouste Gulbenkian, 1999.

KAWASHIMA, Takeyoshi. Japanese Way of legal Thinking. International Journal of Law Libraries, v. 7, n. 1, 1979.

KLICKA, Thomas; RECHBERGER, Walter. Accelerating Civil Litigation in Austria in the Twentieth Century. In: RHEE, C. H. van (Org.). The Law's Delay: Essays on Undue Delay in Civil Litigation. Intersentia, 2004. 
KLEIN, Franz. Vorlesungen über die Praxis des Civilprocess. Wien: Manz, 1900.

KÖNIG, Bernhard. La ZPO Austriaca dopo la Novella del 1983. Rivista di Diritto Processuale, Padova, Cedam, n. 3, 1988.

LEIPOLD, Dieter. Oral and Written Elements within the Introductory Phase of Civil Proceedings. In: CARPI, Federico; ORTELLS, Manuel (Org.). Oralidad y Escritura en un Proceso Civil Eficiente (Oral and Written Proceedings: Efficiency in Civil Procedure). v. I - Ponencias generales e informes nacionales (General reports and national reports). València: International Association of Procedural Law (IAPL), Universitat de València, 2008.

LEVY, Jean Phillipe. La formation de la théorie romaine des preuves. In: Studi in Onore di Siro Solazzi. Napoli: Jovene, 1948.

LEVY-BRUHL, Henri. Recherches sur les Actions de la Loi. Paris: Sirey, 1960.

LOBO DA COSTA, Moacyr. O Agravo no Direito Lusitano. In: .; AZEVEDO, Luiz Carlos de. Estudos de História do Processo: Recursos. Osasco: FIEO, 1996.

LUISO, Francesco p. Il procedimento sommario di cognizione. Disponível em: <www.judicium.it>. Acesso em: 14 jul. 2009.

La conciliazione nel quadro della tutela dei diritti. In: Studi in Onore di Giuseppe Tarzia. t. 2. Milano: Giuffrè, 2005.

MADEIRA, Hélcio Maciel França. História da Advocacia: origens da profissão de advogado no direito romano. São Paulo: Revista dos Tribunais, 2002.

MADERO, Luis. Comentario Exegético al Código de Derecho Canónico. 3. ed. v. IV/2. Pamplona: Universidade Navarra, 2002.

MANIOTIS, Dimitris. Some Remarks concerning the Pre-Trial Stadium and the Proceeding before the Court according to the Greek Code of Civil Procedure. In: CARPI, Federico; ORTELLS, Manuel (Org.). Oralidad y Escritura en un Proceso Civil Eficiente (Oral and Written Proceedings: Efficiency in Civil Procedure). v. I Ponencias generales e informes nacionales (General reports and national reports). València: International Association of Procedural Law (IAPL), Universitat de València, 2008.

MARCATO, Antonio Carlos. (Org.). Código de Processo Civil Interpretado. São Paulo: Atlas, 2004.

MARTÍN. Oralidad y eficiencia del proceso civil: Ayer, hoy, y mañana. In: CARPI, Federico; ORTELLS, Manuel (Org.). Oralidad y Escritura en un Proceso Civil Eficiente (Oral and Written Proceedings: Efficiency in Civil Procedure). v. II Comunicaciones (Presentations). València: International Association of Procedural Law (IAPL), Universitat de València, 2008. 
MARTINS, Pedro Batista. Em defesa do Ante-Projeto de CPC. In: Processo Oral. Rio de Janeiro: Forense, 1940.

MEIRA, Sílvio Augusto de Bastos. Noções Gerais de Processo Civil Romano. Roma: Tripi \& Di Maria, 1963.

METRO, Antonino. Unus testis nullus testis. In: CAIRNS, John; ROBINSON, Olivia (Org.). Critical Studies in Ancient Law.Comparative Law and Legal History. Hart: Antwerp, 2001.

METZGER, Ernest. Roman Judges, Case Law, and Principles of Procedure. Law and History Review, Illinois, University of Illinois, n. 22, summer, 2004.

Litigation in Roman Law. New York: Oxford University, 2008.

MICCOLIS, Giuseppe. La conciliazione e la disciplina del nuovo processo introdotto con il D.Lgs. n. 5 del 2003. In: Studi in Onore di Giuseppe Tarzia. t. 2. Milano: Giuffrè, 2005.

MICHELI, Gian Antonio. L’onere della prova. Padova: Cedam, 1966.

MIYAZAWA, Setsuo. Taking Kawashima Seriously: A review of Japanese Research on Japanese Legal Consciousness and Disputing Behavior. Law and Society Review, n. 219, 1987-1988.

MILLAR, Robert Wyness. Formative Principles of Civil Procedure. In: ENGELMANN, Arthur (Org.). A History of Continental Civil Procedure. New York: Rothman Reprints; Augustus Kelley, 1969.

MONETA, Paolo. Processo giudiziario canonico. Enciclopedia del diritto, Giuffrè, v. XXXVI, 1987.

MORAES, José Rubens de. Sociedade e Verdade - Evolução Histórica da Prova. Tese (Doutorado) - Faculdade de Direito da Universidade de São Paulo, 2008.

MORATO, Francisco. A Oralidade. Revista Forense. Rio de Janeiro, p. 11-18, maio 1938.

MORENO RESANO, Esteban. La acepción de interlocutio en derecho romano. Revue Internationale des Droits de l'Antiquité, $3^{\mathrm{e}}$ Série, t. L, 2003.

MURRAY, Peter; STÜRNER, Rolf. German Civil Justice. Durham: Carolina Academic, 2004.

NERY JÚNIOR, Nelson. Audiência Preliminar e Saneamento do processo. In: TEIXEIRA, Sálvio Figueiredo (Coord.). Reforma do Código de Processo Civil. São Paulo: Saraiva, 1996.

NÖRR, Knut Wolfgang. Rechtsgeschichtliche Apostillen zur Clementine Saepe. In: RHEE, C. H. van (Org.). The Law's Delay: Essays on Undue Delay in Civil Litigation. Intersentia, 2004. 
NUNES LEAL, Victor. Ignorância, rotina e chicana - os três maiores inimigos do Processo Oral. Revista Forense, maio 1938, p. 121.

OBERHAMMER, Paul. Speeding up Civil Litigation in Austria: past and present instruments. In: RHEE, C. H. van (Org.). The Law's Delay: Essays on Undue Delay in Civil Litigation. Intersentia, 2004.

OLIVEIRA, Carlos Alberto Alvaro de. Do formalismo no processo civil: proposta de um formalismo-valorativo. 3. ed. São Paulo: Saraiva, 2009.

ODA, Hiroshi. Japanese Law. 3. ed., New York: Oxford University, 2009.

OTA, Shozo. Reform of Civil Procedure in Japan. American Journal of Comparative Law, n. 49, 2001.

PÉREZ-RAGONE, Álvaro; PALOMO VÉLEZ, Diego. Oralidad y prueba: comparación y análisis crítico de las experiencias reformadoras del proceso civil en Alemania y España. Revista de Derecho de la Pontificia Universidad Católica de Valparaíso, n. XXXII, Valparaíso, 2009.

PEYRANO, Jorge W. La Prueba entre la Oralidad y la Escritura. In: CARPI, Federico; ORTELLS, Manuel (Org.). Oralidad y Escritura en un Proceso Civil Eficiente (Oral and Written Proceedings: Efficiency in Civil Procedure). v. I - Ponencias generales e informes nacionales (General reports and national reports). València: International Association of Procedural Law (IAPL), Universitat de València, 2008.

PICÓ I JUNOY, Juan; CERRATO GURI, Elisabet. El control de la valoración judicial de las pruebas personales en la segunda instancia civil. In: CARPI, Federico; ORTELLS, Manuel (Org.). Oralidad y Escritura en un Proceso Civil Eficiente (Oral and Written Proceedings: Efficiency in Civil Procedure). v. II - Comunicaciones (Presentations). València: International Association of Procedural Law (IAPL), Universitat de València, 2008.

PÖLÖNEN, Janne. Plebeians and Repressions of Crime the in Roman Empire: from the torture of convicts to the torture of suspects. Revue Internationale des Droits de L'Antiquité, t. LI, 2004.

POTHIER, Robert Joseph. Pandectae Justiniane, in novum ordinem digestae, cum legibus, codicis, et novellis, que jus pandectarum confirmant, explicant, aut abrogant. Tomus Primus. Paris: Fournier, 1818.

POZZEBON, Gustavo R. Chaim; ROMANO, Michel Betenjane. O papel do Ministério Público na Pacificação de Conflitos. In: GRINOVER, Ada Pellegrini; WATANABE, Kazuo; LAGRASTA NETO, Caetano (Coord.). Mediação $e$ Gerenciamento do Processo - Revolução na Prestação Jurisdicional. São Paulo: Atlas, 2008. 
RECHBERGER, Walter; KLICKA, Thomas. Accelerating Civil Litigation in Austria in the Twentieth Century. In: RHEE, C. H. van (Org.). The Law's Delay: Essays on Undue Delay in Civil Litigation. Intersentia, 2004.

RIBAS, Antonio. Consolidação das Leis do Processo Civil commentada. v. 1, Rio de Janeiro: Dias da Silva Júnior, 1879.

RIBEIRO, José Pedro. Sobre a economia dos Juizes de primeira Instancia no nosso Reino desde o Governo dos Reis de Leão. Dissertação XXI. In: Dissertações Chronologicas e criticas sobre a historia e jurisprudência ecllesiastica e civil de Portugal, t. V. Lisboa: Academia Real das Sciencias, 1836.

RICHARD, Marie-Dominique, L'enseignement oral de Platon. Paris : Cerf, 2005

ROMANO, Michel Betenjane; GAJARDONI, Fernando da Fonseca; LUCHIARI, Valeria Ferioli Lagrasta. O Gerenciamento do Processo. In: GRINOVER, Ada Pellegrini; WATANABE, Kazuo; LAGRASTA NETO, Caetano (Coord.). Mediação $e$ Gerenciamento do Processo - Revolução na Prestação Jurisdicional. São Paulo: Atlas, 2008.

RÜHL, Giesela. Preparing Germany for the $21^{\text {st }}$ Century: The Reform of the Code of Civil Procedure. German Law Journal, v. 6, n. 6, jun. 2005.

SANTOS, Moacyr Amaral. Prova Judiciária no Cível e Comercial. v. II. 4. ed. São Paulo: Max Limonad, 1971.

. Contra o processo autoritário. Revista da Faculdade de Direito da Universidade de São Paulo, v. 54, fascículo 2, 1959.

SATO, Yasunobu. Cultural Conflict in Dispute Processing under Globalization: International Coopertation for Legal Aid in Asia. Asia-Pacific Economic Cooperation discussion paper n. 36. Disponível em: <http://www.gsid.nagoyau.ac.jp/project/apec/outcomes/paper00/36/Sato.pdf>. Acesso em: 05 jul. 2009.

SIEGEL, Larry J. Introduction to Criminal Justice. 12. ed. Wodsworth: Belmont, 2009.

SIDOU, José Maria Othon. A Vocação publicística do Procedimento Romano. Recife: Câmbio, 1955.

STADLER, Astrid. The multiples roles of Judges and Attorneys in Modern Civil Litigation. Hastings International and Comparative Law Review, n. 27, 2003.

STÜRNER, Rolf; MURRAY, Peter. German Civil Justice. Durham: Carolina Academic, 2004.

TARUFFO, Michele. Orality and writing as factors of efficiency in civil litigation. In: CARPI, Federico; ORTELLS, Manuel (Org.). Oralidad y Escritura en un Proceso Civil Eficiente (Oral and Written Proceedings: Efficiency in Civil Procedure). v. I Ponencias generales e informes nacionales (General reports and national reports). València: International Association of Procedural Law (IAPL), Universitat de València, 2008. 
TARUFFO, Michele. Considerazioni su prova e motivazione. In: MEDINA, José Miguel Garcia; CRUZ, Luana Pedrosa de Figueiredo; CERQUEIRA, Luis Otávio Sequeira de; GOMES JÚNIOR, Luiz Manoel (Coord.). Os Poderes do Juiz e o Controle das Decisões Judiciais - Estudos em Homenagem à Professora Teresa Arruda Alvim Wambier. São Paulo, Revista dos Tribunais, 2008.

STORME, Marcel. More voice, less print - Why Court proceedings should become more oral. In: CARPI, Federico; ORTELLS, Manuel (Org.). Oralidad y Escritura en un Proceso Civil Eficiente (Oral and Written Proceedings: Efficiency in Civil Procedure). v. I - Ponencias generales e informes nacionales (General reports and national reports). València: International Association of Procedural Law (IAPL), Universitat de València, 2008.

SURGIK, Aloísio. Lineamentos do Processo Civil Romano. Curitiba: Livro é Cultura, 1990.

TOZZI, Antonio. L'evoluzione del giudizio di fatto nel processo romano. Rivista di Diritto Processuale, Padova, Cedam, Parte I, V. XVII, 1940.

VELU, Jacques. La Convention Européenne des Droits de L'Homme et les garanties fondamentales des parties dans le procès civil. In: CAPPELLETTI, Mauro ; TALLON, Denis (Ed.). Fundamental Guarantees of the Parties in Civil Litigation. Milano; New York: Giuffrè; Oceana, 1971.

WACH, Adolph. Vorträge über die Reichs-Civilprocessordnung. Bonn: Adolf Marcus, 1879. . Mündlichkeit im österreichischen Civilprocess-Entwurf. Wien: Manz, 1895.

WALKER, Janet; WATSON, Garry. New Technologies and the civil litigation process: Common Law General Report. In: GRINOVER, Ada Pellegrini; CALMON, Petrônio (Org.). Direito Processual Comparado. XIII World Congress of Procedural Law. Rio de Janeiro: Forense, 2007.

WALTER, Gerhard. Freie Beweiswürdigung. Tübingen: J.C.B. Mohr (Paul Siebeck), 1979.

Libre Apreciación de La Prueba, Investigación acerca del significado, las condiciones y límites del libre convencimiento judicial. Tradução de Tomás Banzhaf. Bogotá: Temis, 1985.

The German Civil Procedure Reform Act 2002: Much ado about nothing? In: Studi di Diritto Processuale Civile in Onore di Giuseppe Tarzia. Milano: Giuffrè, 2005.

WAMBIER, Luiz Rodrigues. A Nova Audiência Preliminar. Revista de Processo, São Paulo, Revista dos Tribunais, n. 80, out./dez., 1995.

WANG, Hongliang. Civil pre-trial procedure in China. In: CARPI, Federico; ORTELLS, Manuel (Org.). Oralidad y Escritura en un Proceso Civil Eficiente (Oral and Written Proceedings: Efficiency in Civil Procedure). v. I - Ponencias generales e informes nacionales (General reports and national reports). València: International Association of Procedural Law (IAPL), Universitat de València, 2008. 


\section{DADOS ESTATÍSTICOS}

CONSELHO NACIONAL DE JUSTIÇA. Justiça em Números 2008. Disponível em: <www.cnj.jus.br>. Acesso em: 09 jul. 2009.

STATISTISCHES BUNDESAMT DEUTSCHLAND. Statistische Jahrbuch 2008 für die Bundesrepublik Deutschland, capítulo 10 (Justiz). Disponível em: <www.destatis.de>. Acesso em: 09 jul. 2009. 